
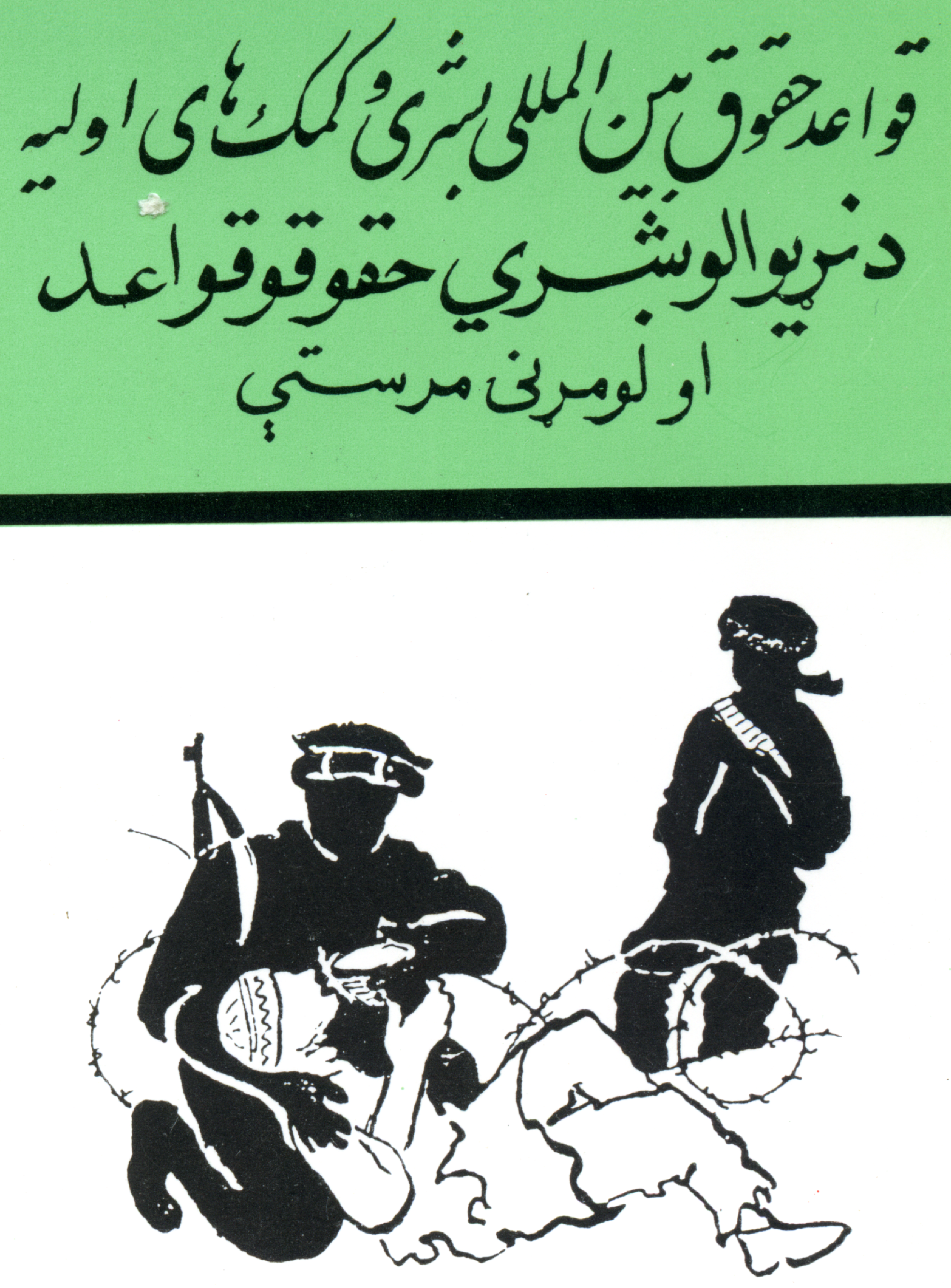

Rules of International

Humanitarian Law \&

\title{
Find Aid
}

Gari and Pasbotolension

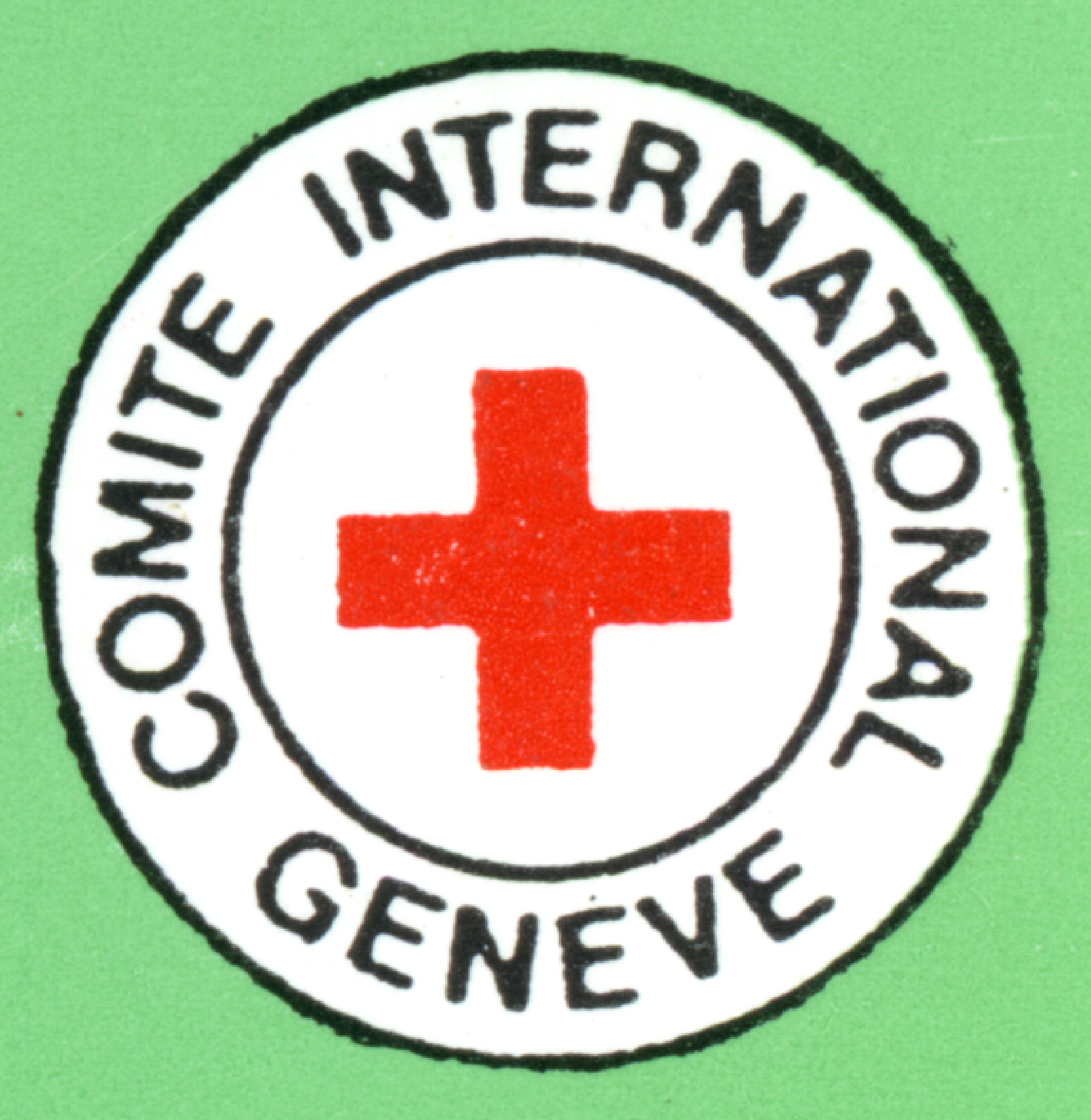




$$
\begin{aligned}
& \text { ו-.-. }
\end{aligned}
$$

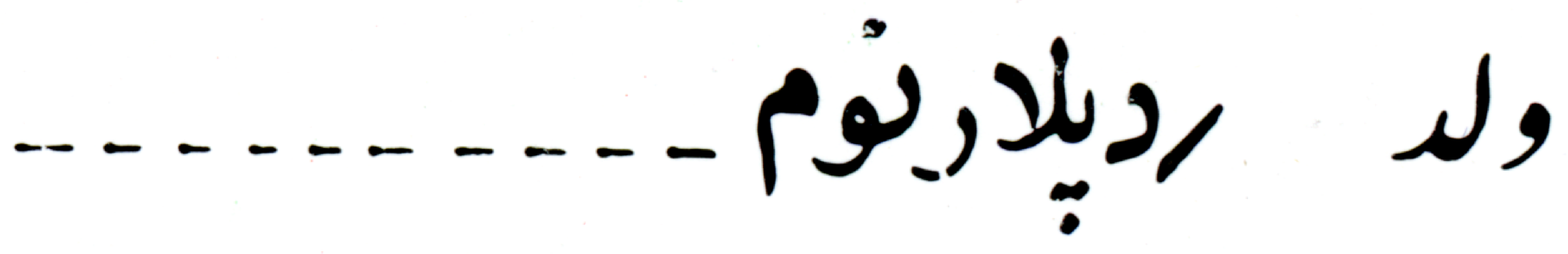

$$
\begin{aligned}
& \text { ن............. } \\
& \text { וT, }
\end{aligned}
$$

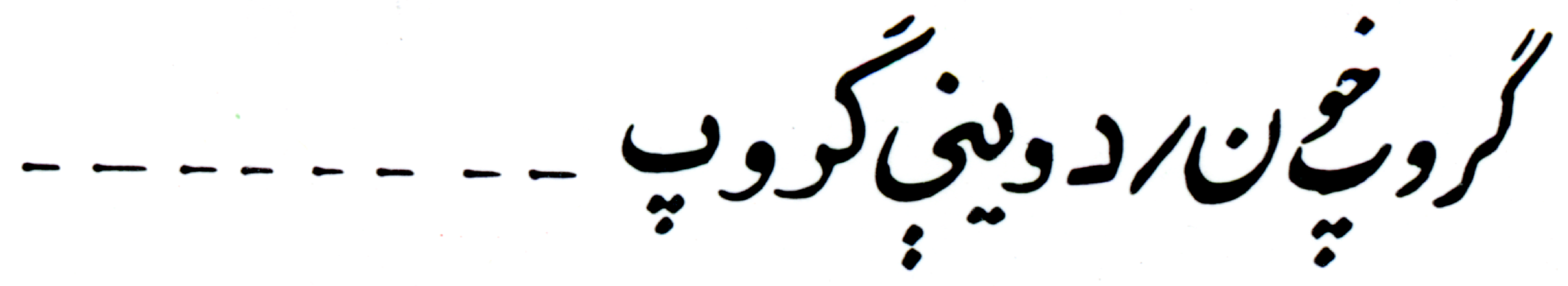
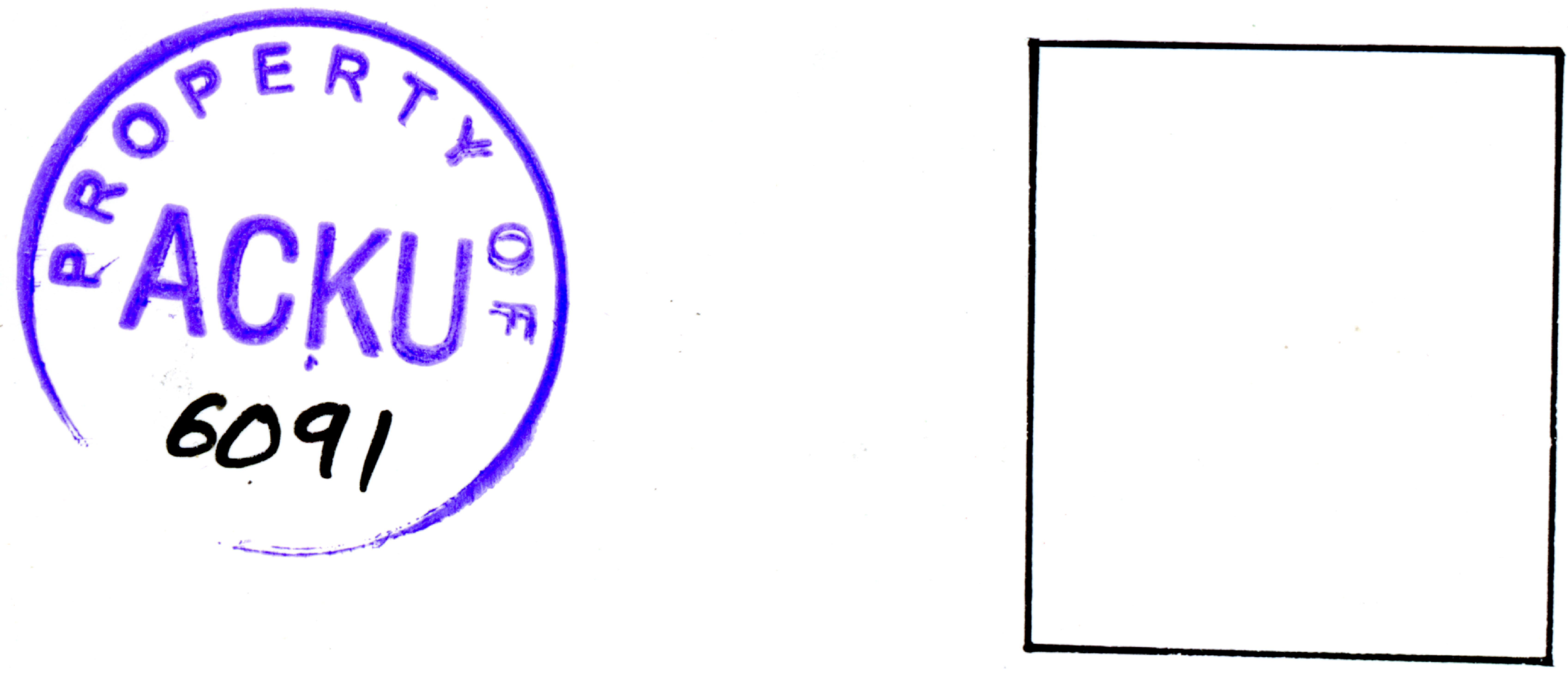


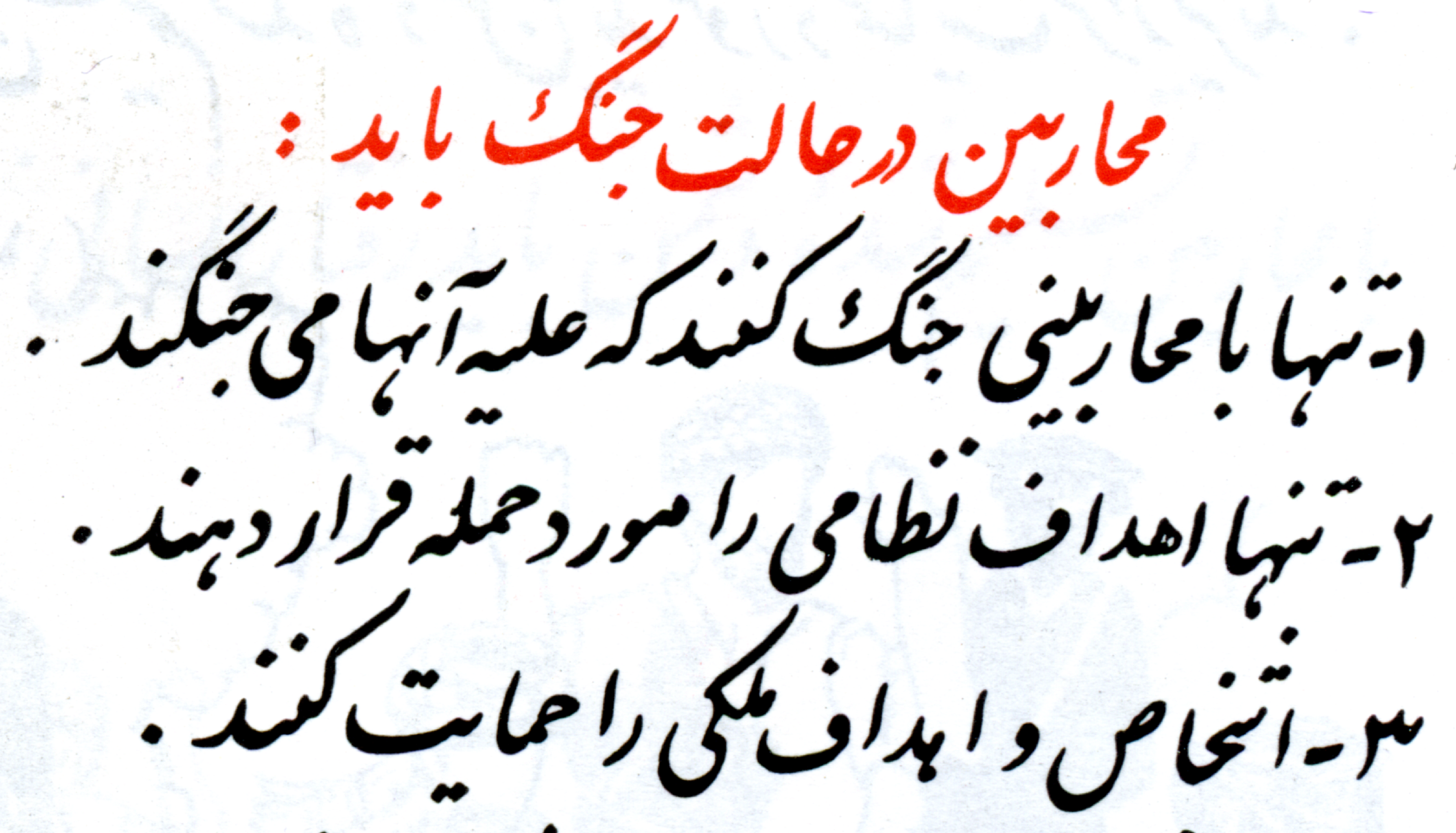

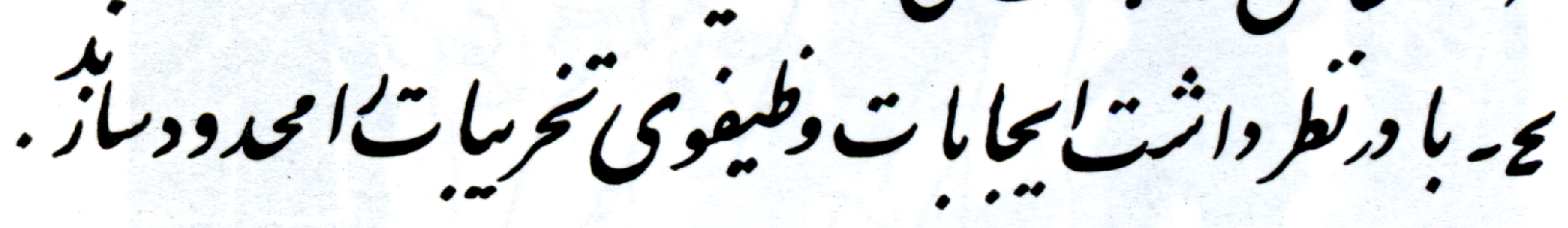

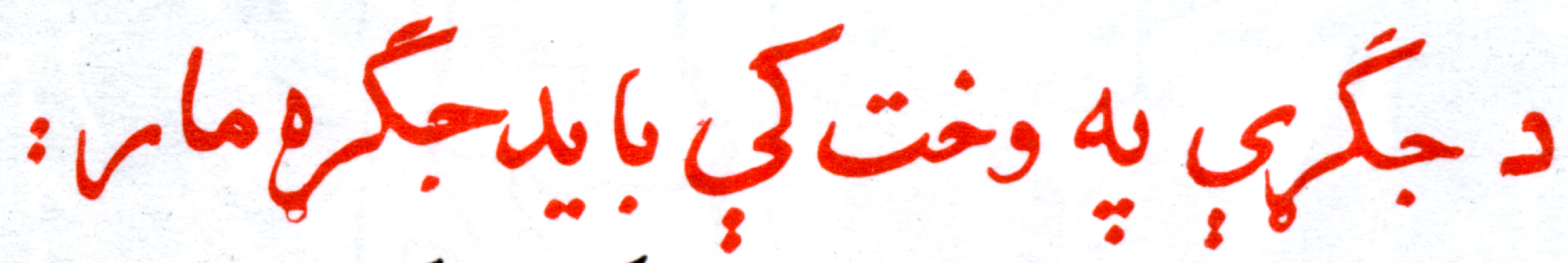

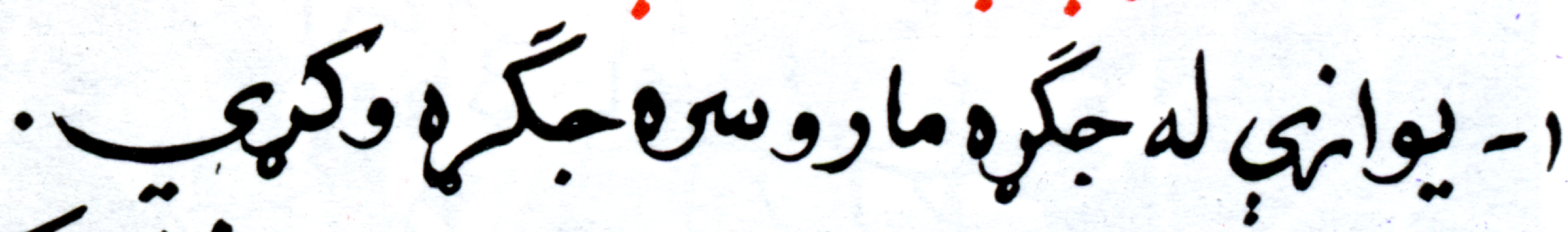

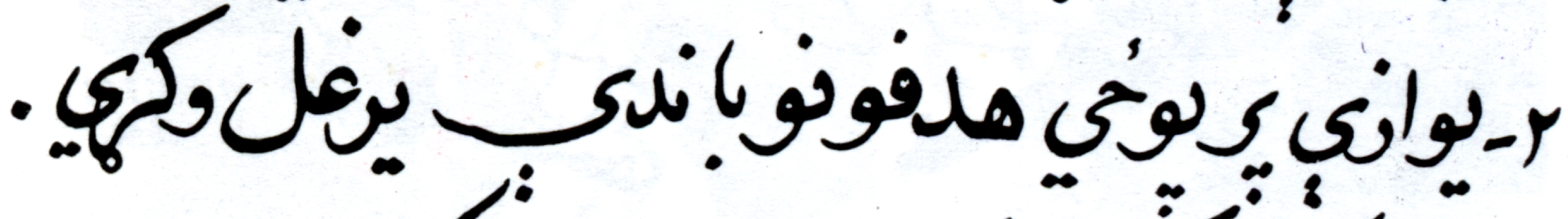

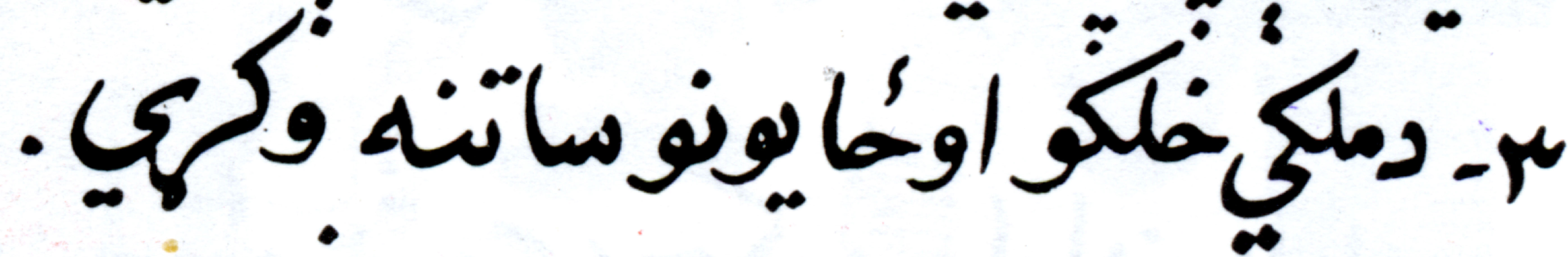

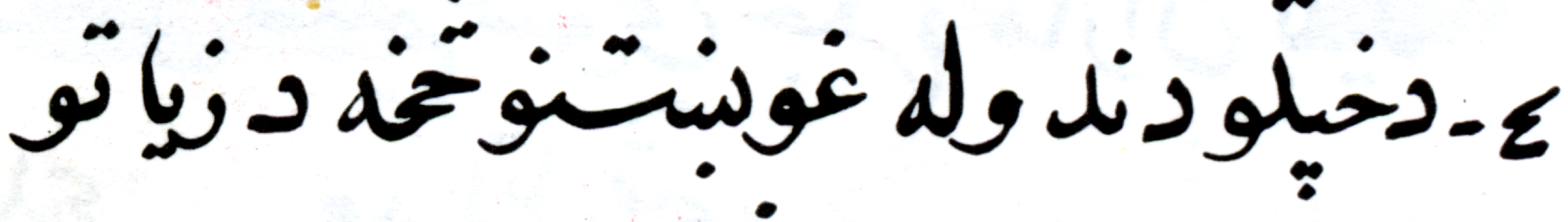

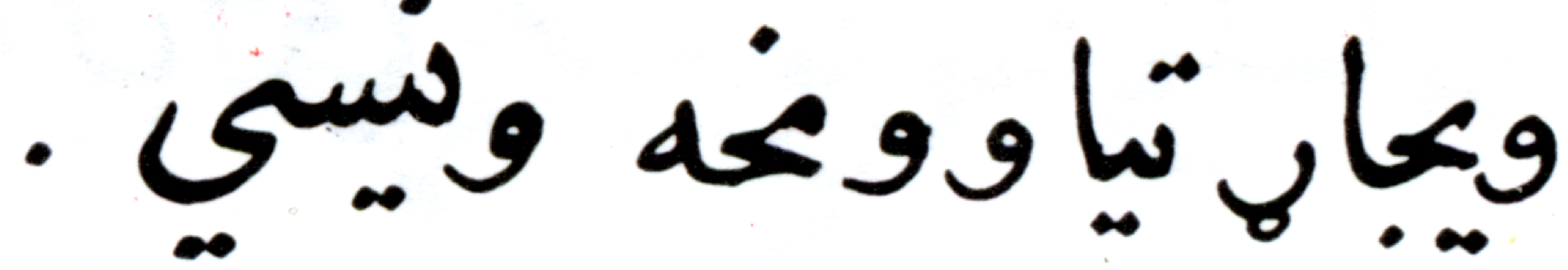




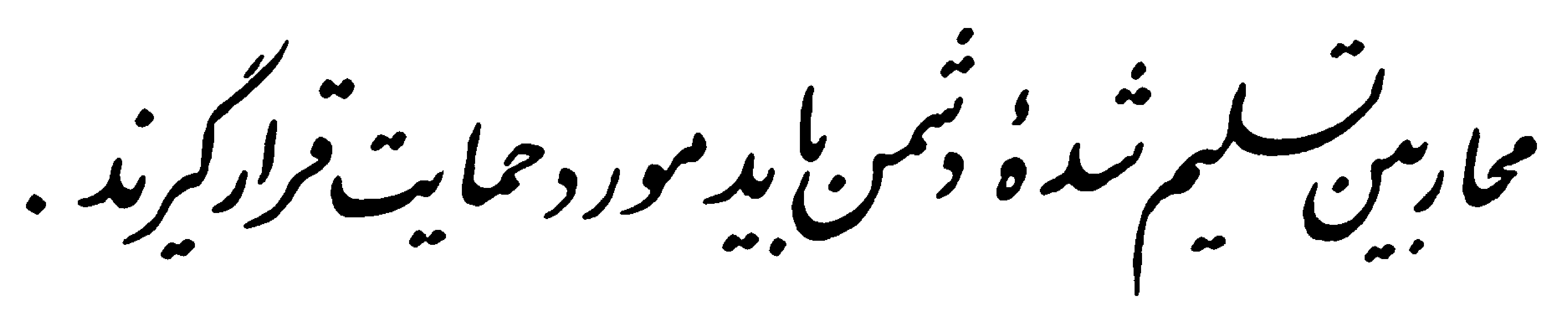

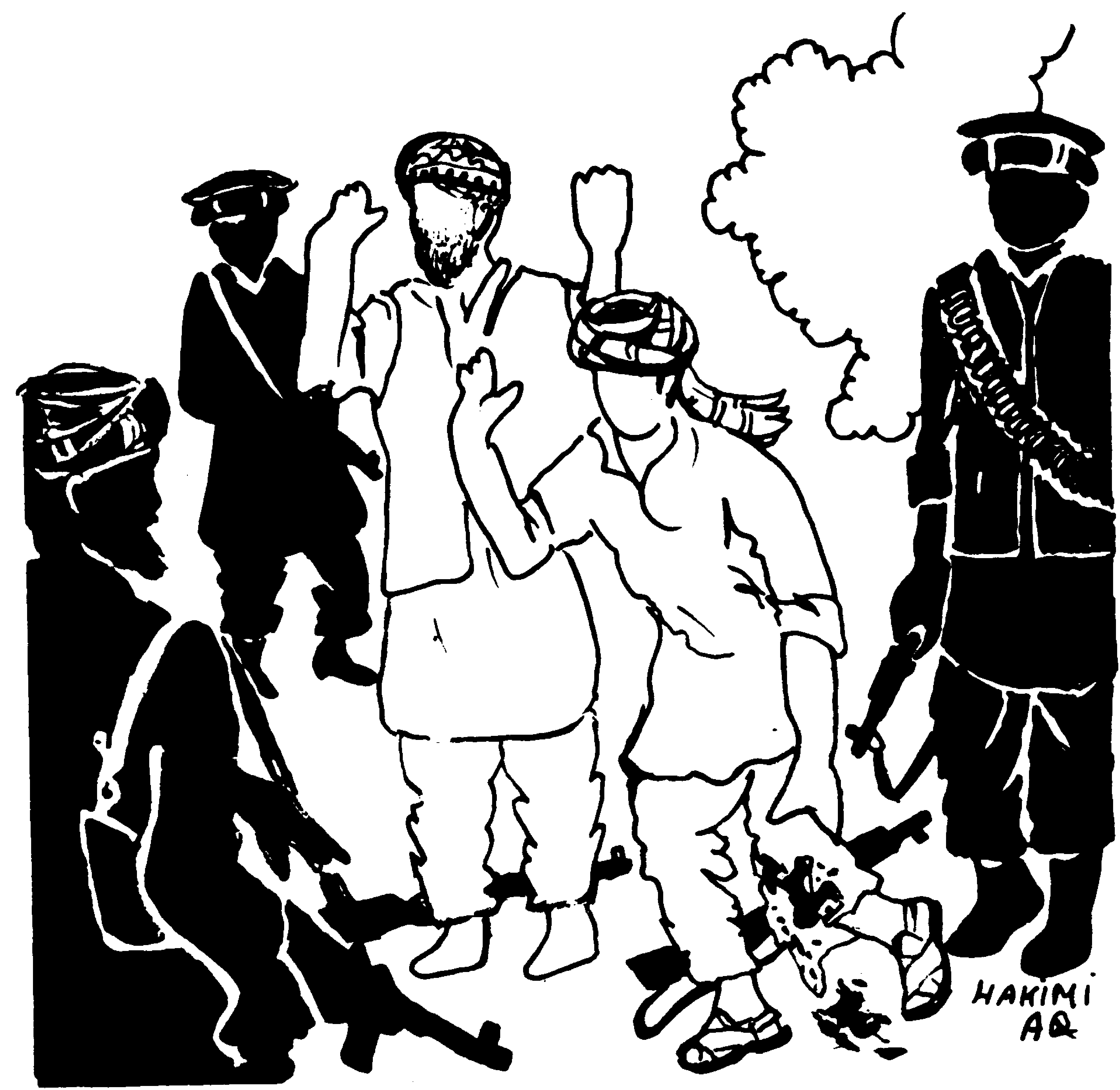

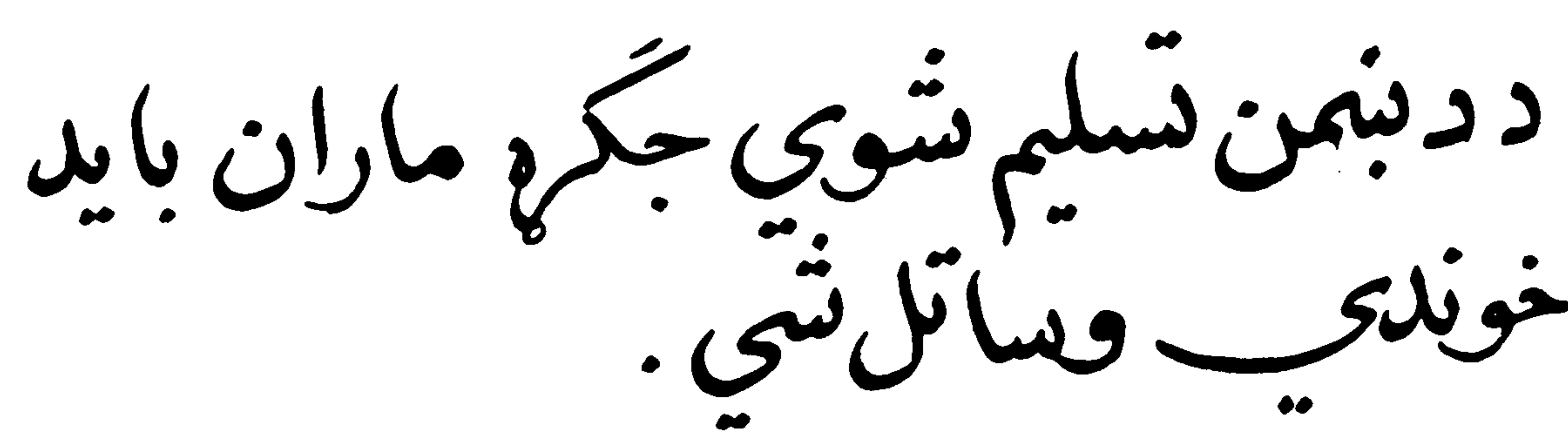




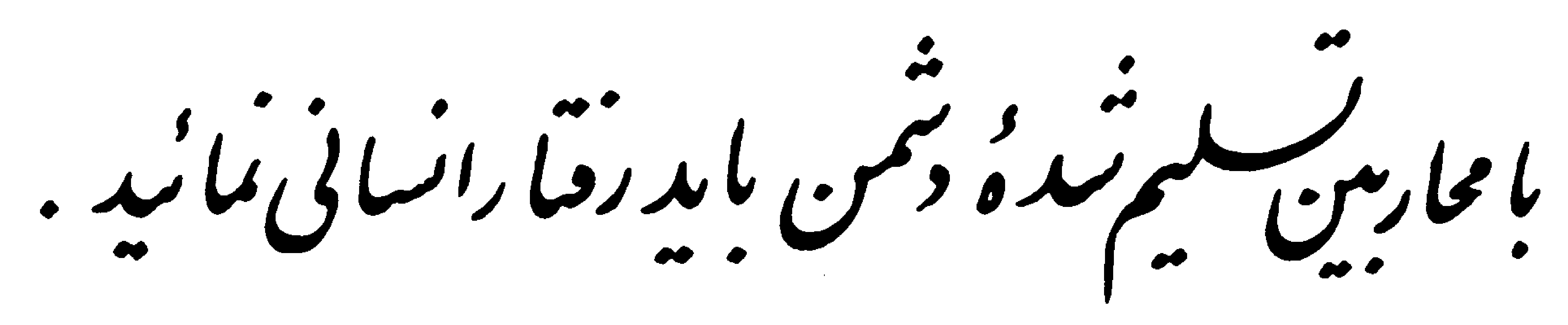

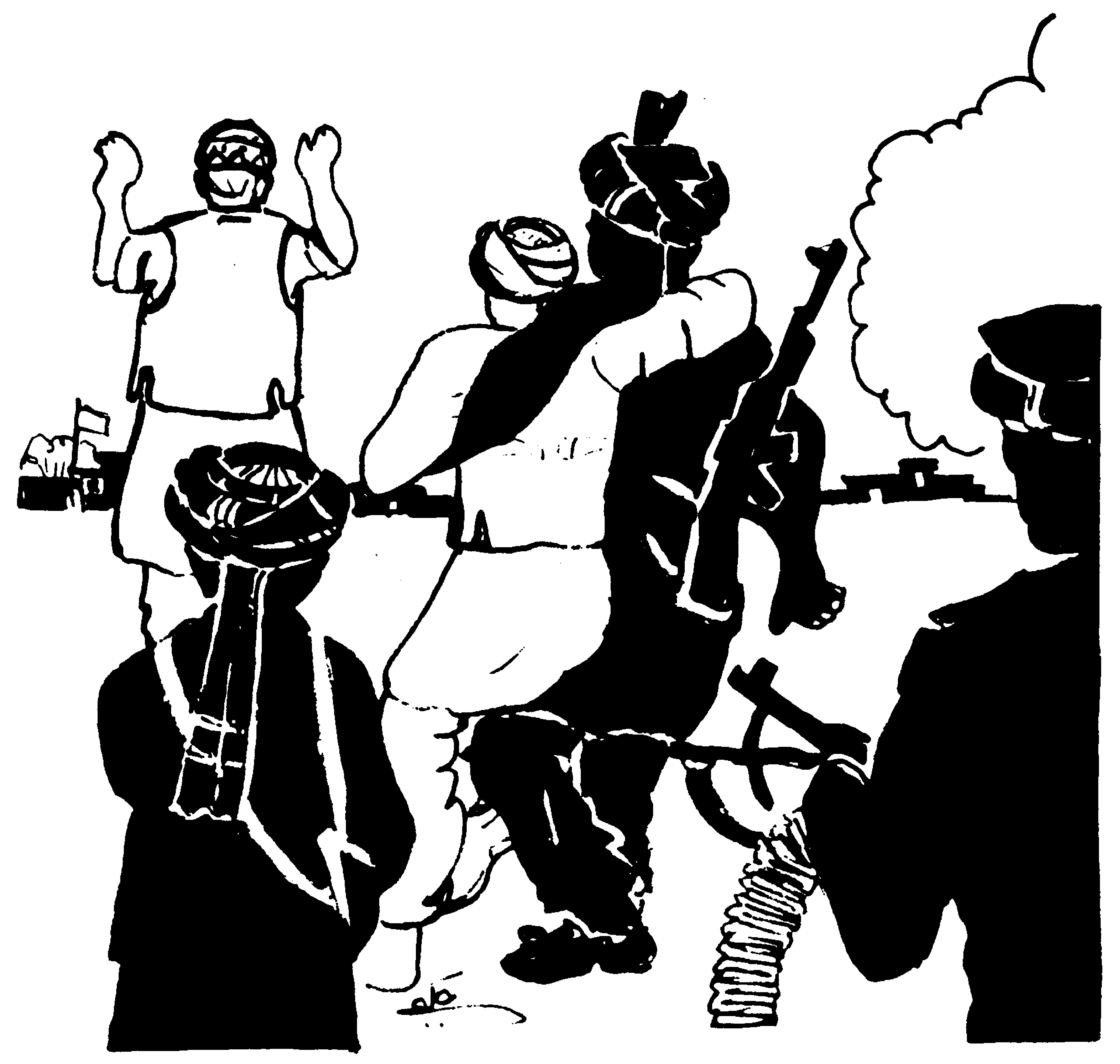

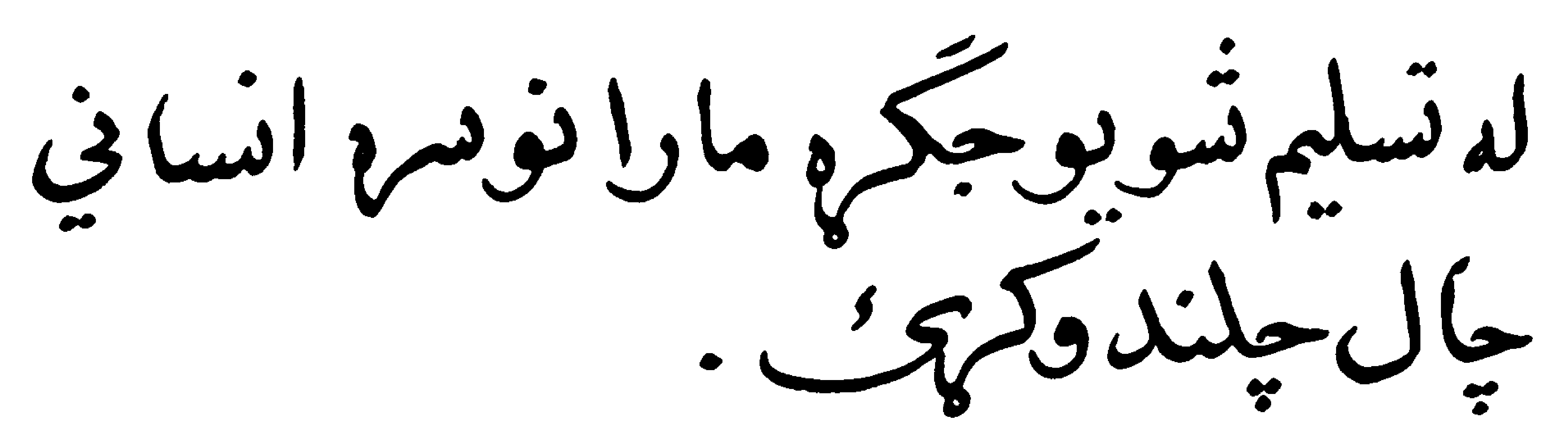





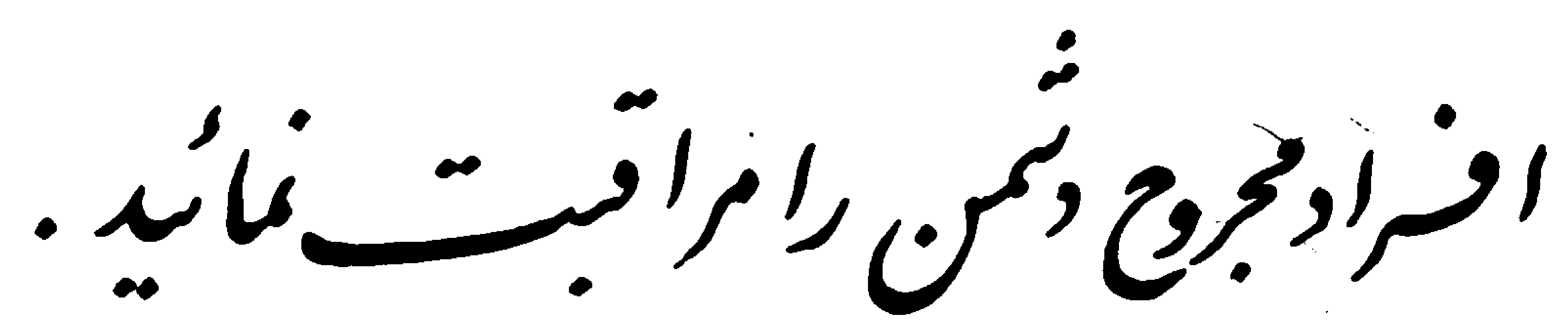

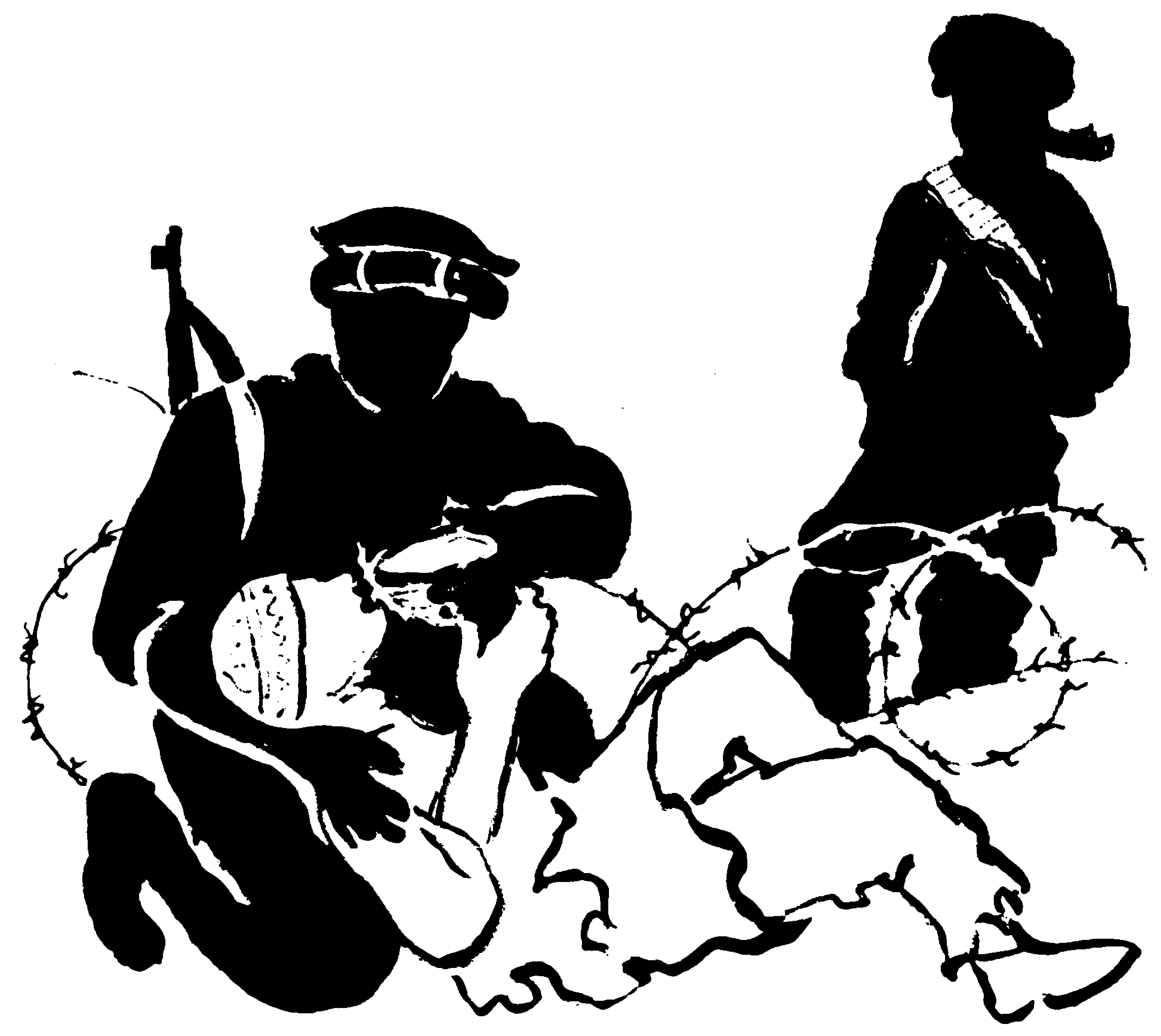

د دبنمن ديّانوساته اوخامهنه وكئ. 



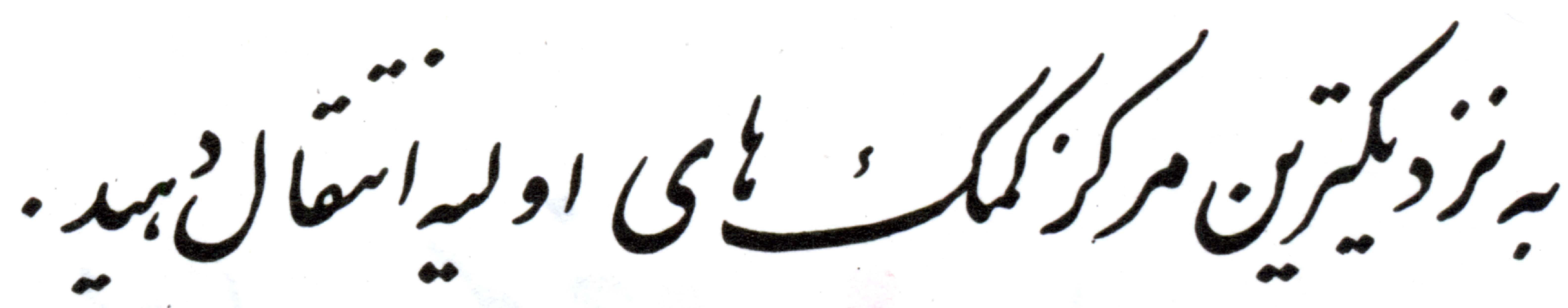

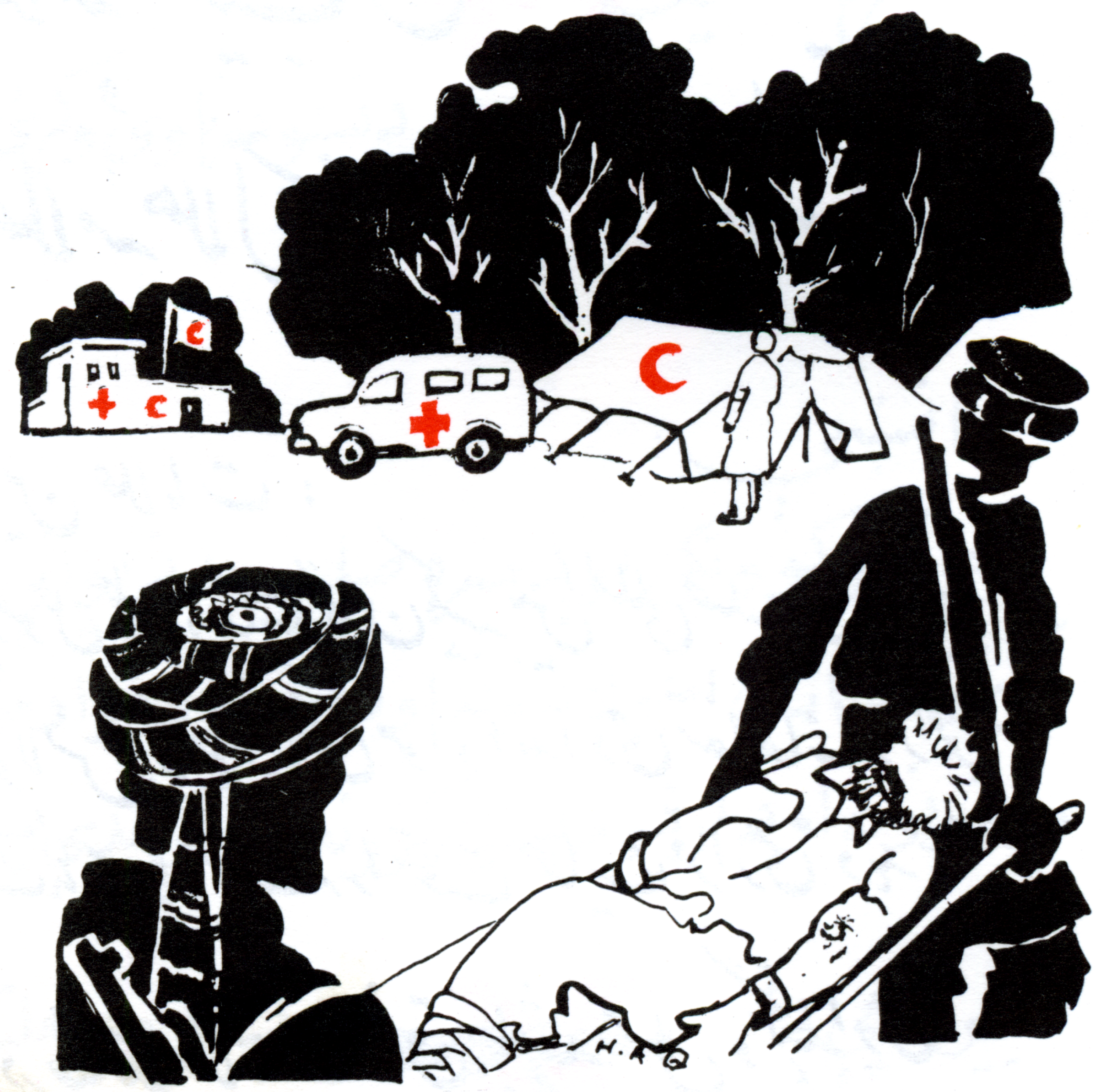

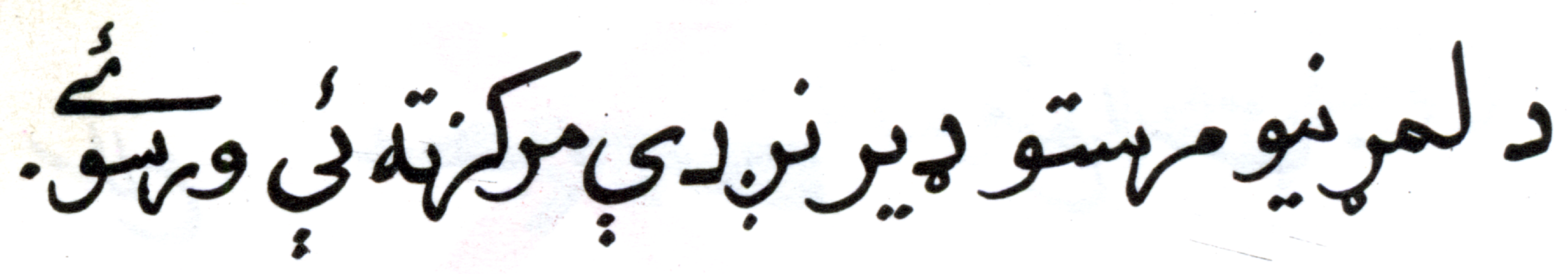


$A: \infty$

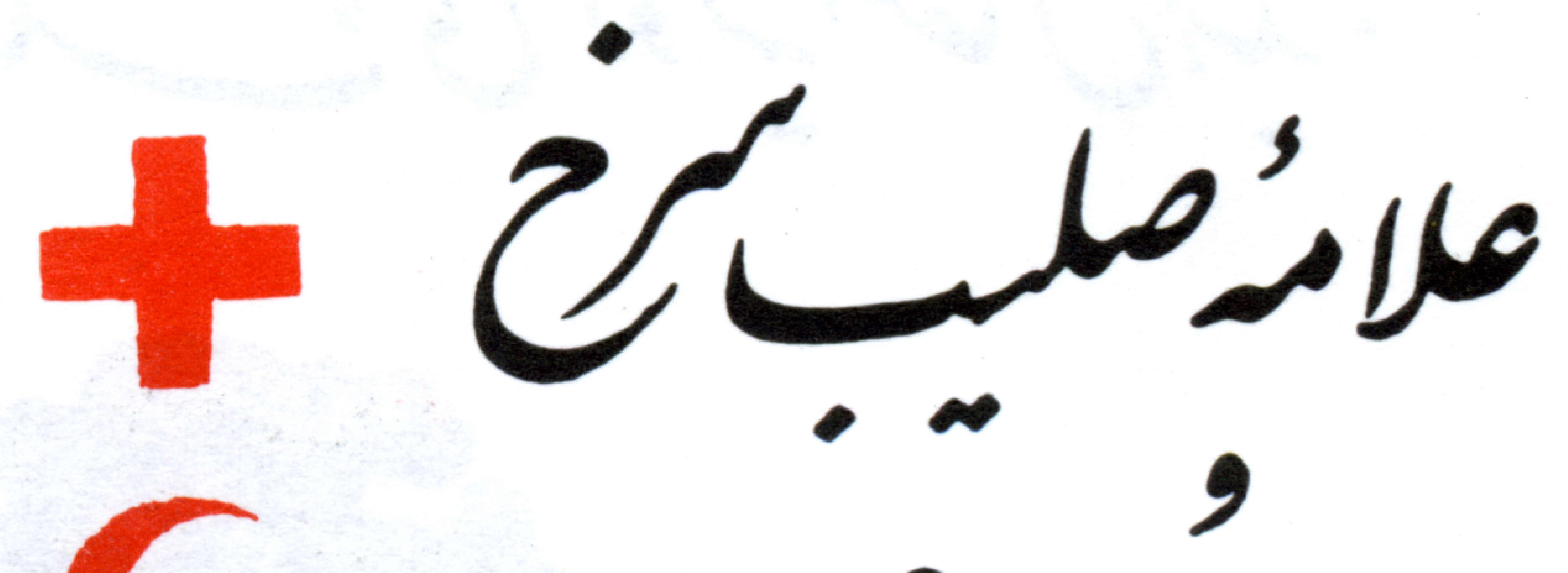

رامحمهاء

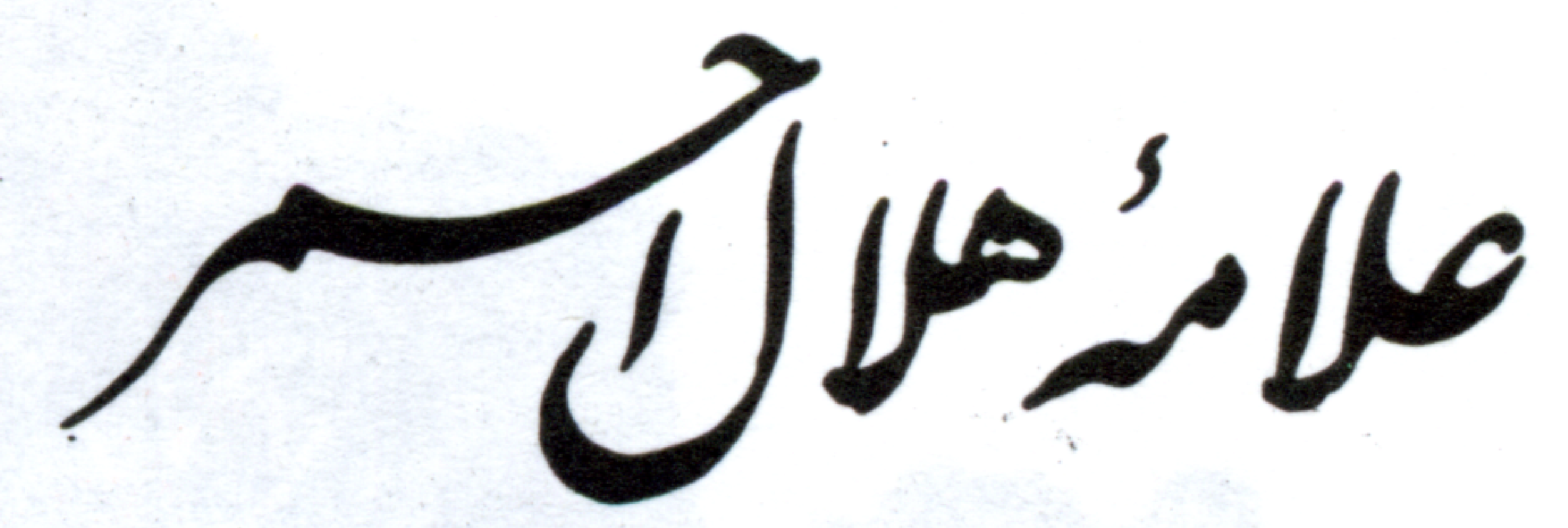

$$
\begin{aligned}
& \text { : }
\end{aligned}
$$

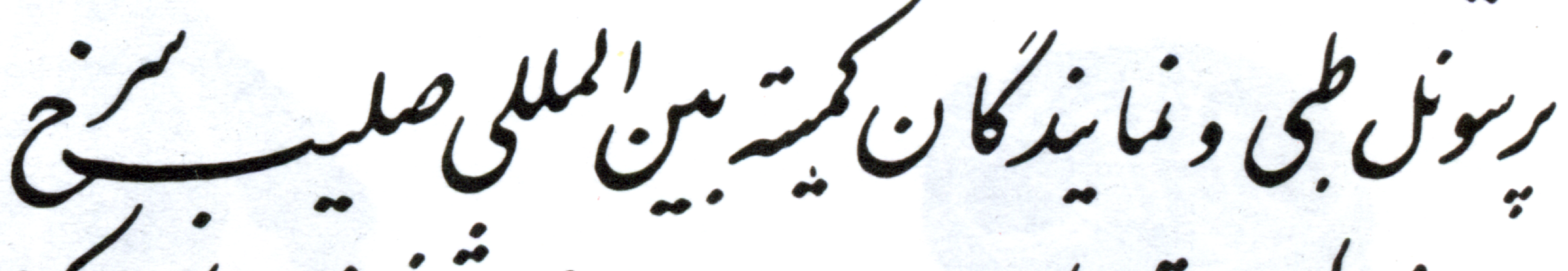

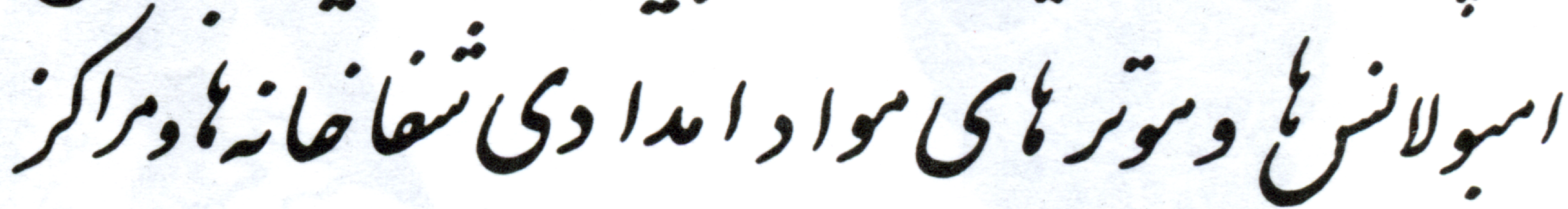

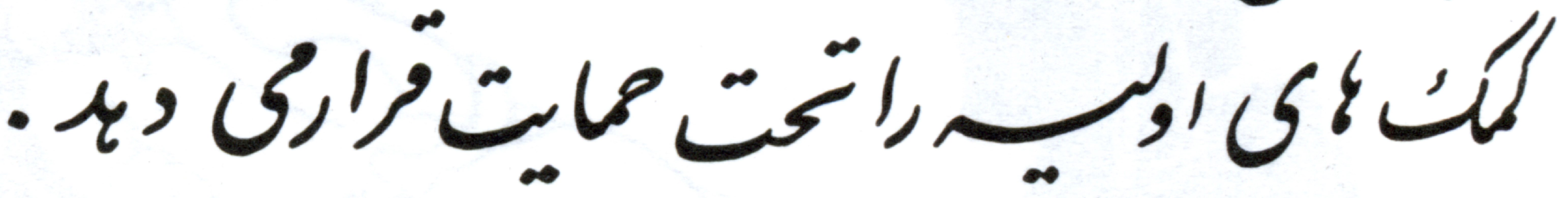

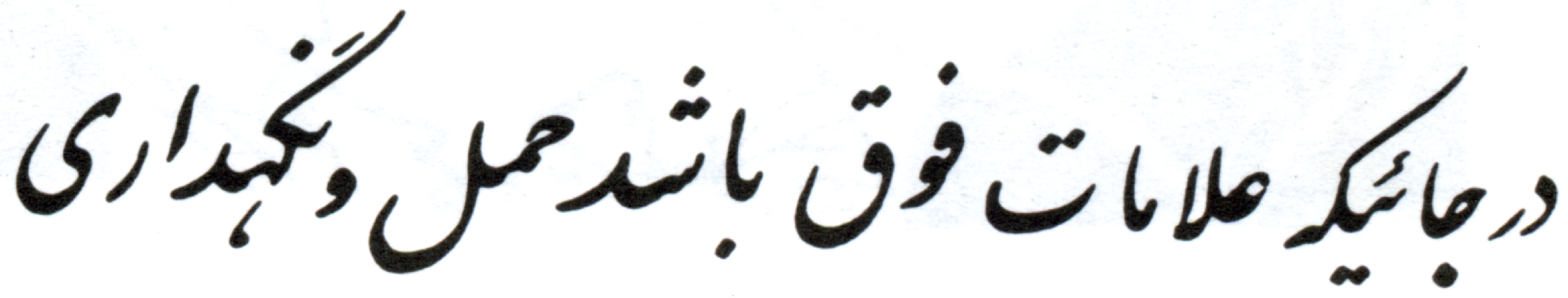

$$
\begin{aligned}
& \text { منّح' }
\end{aligned}
$$
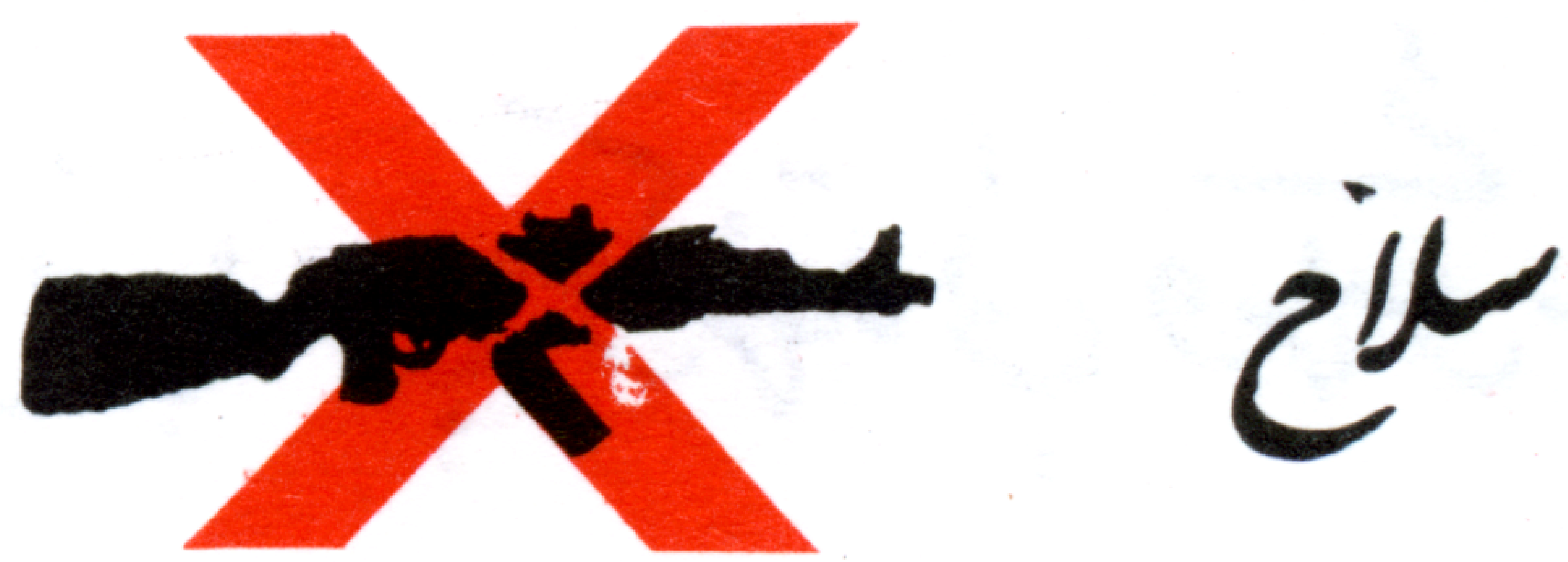
دلموصليب

دنبنودنأوىوكئُ.

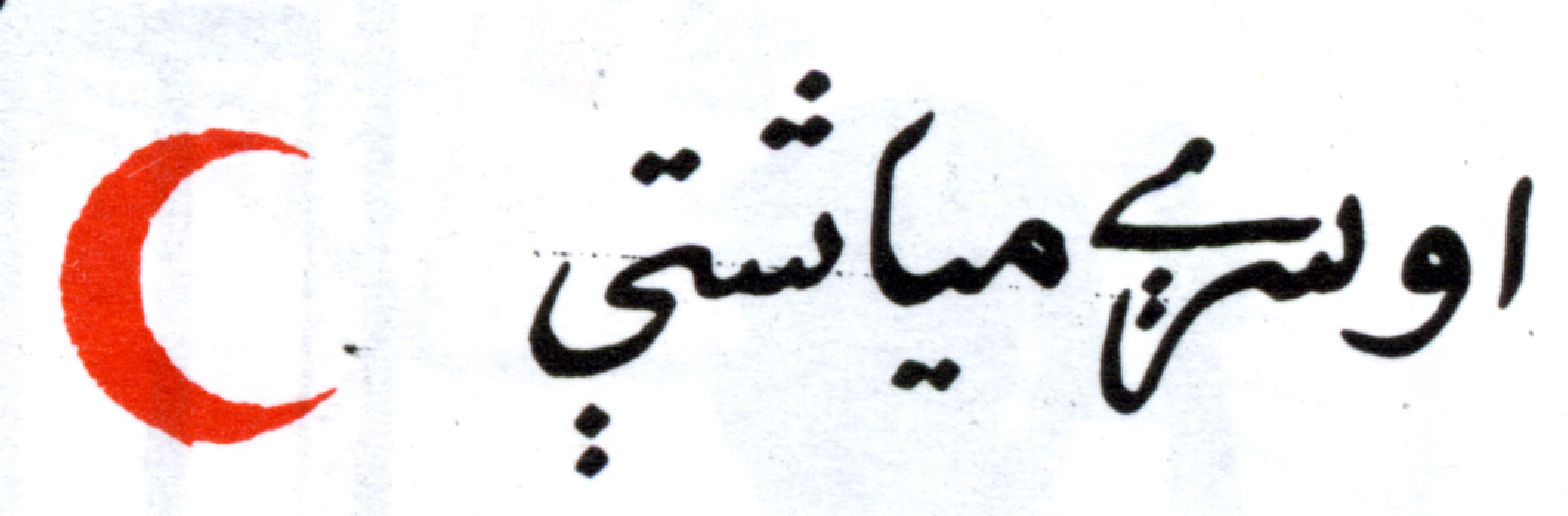

دانسنيح

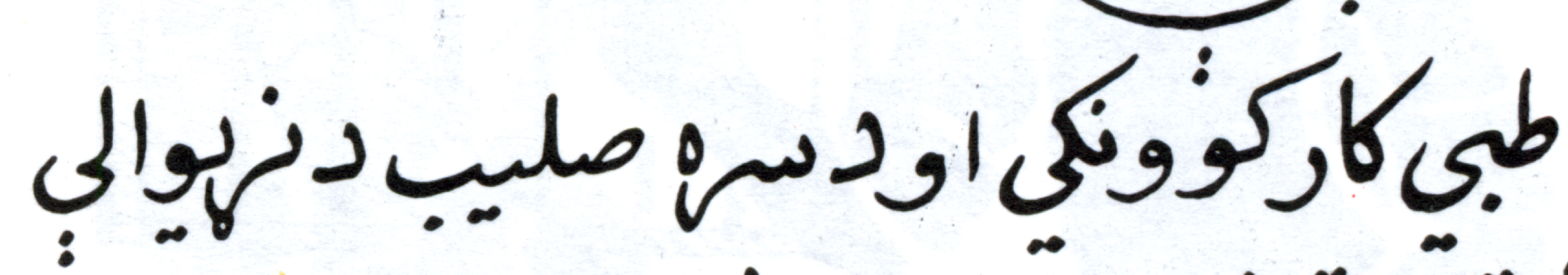

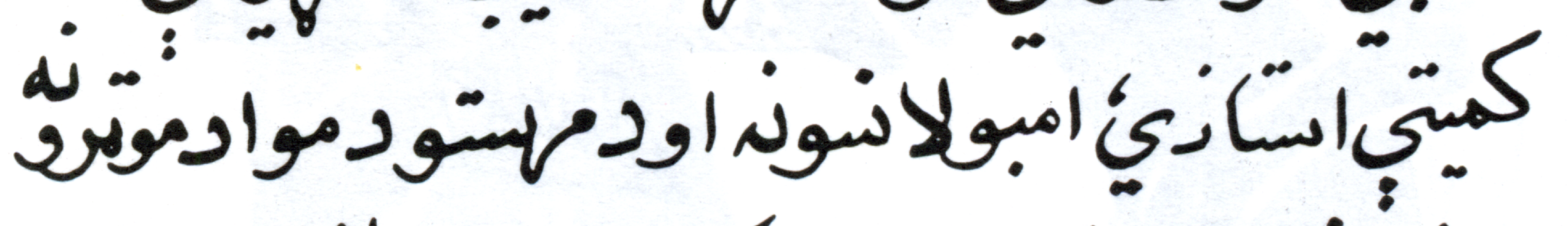

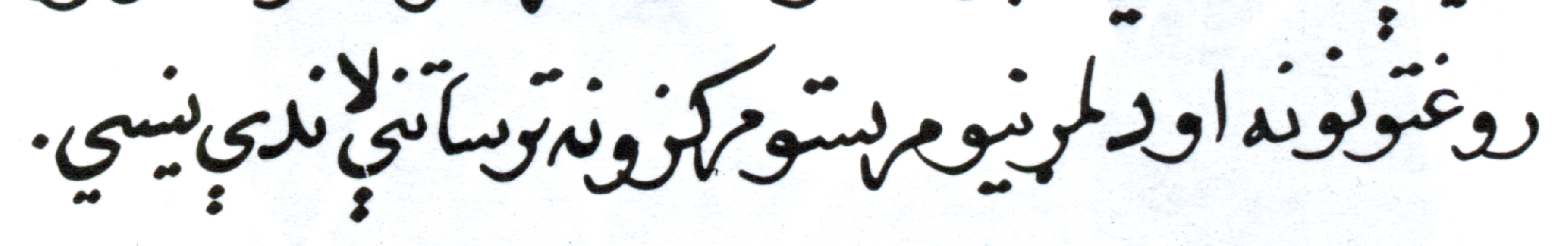

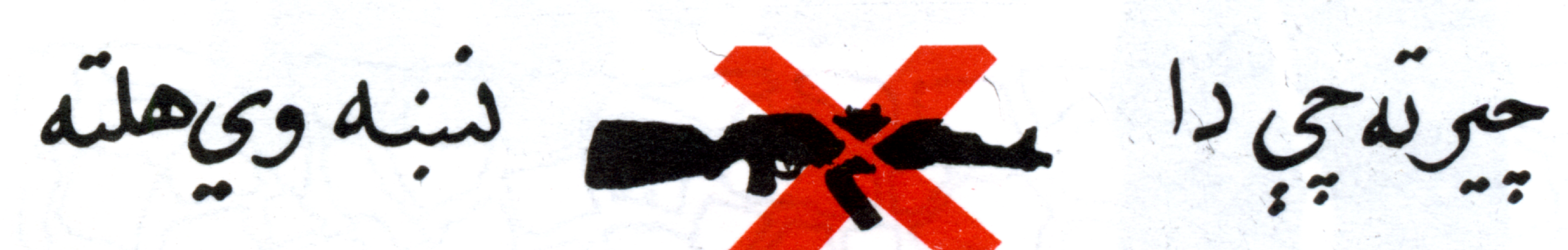

دوسلي مهل اوناتزمنعدي. 


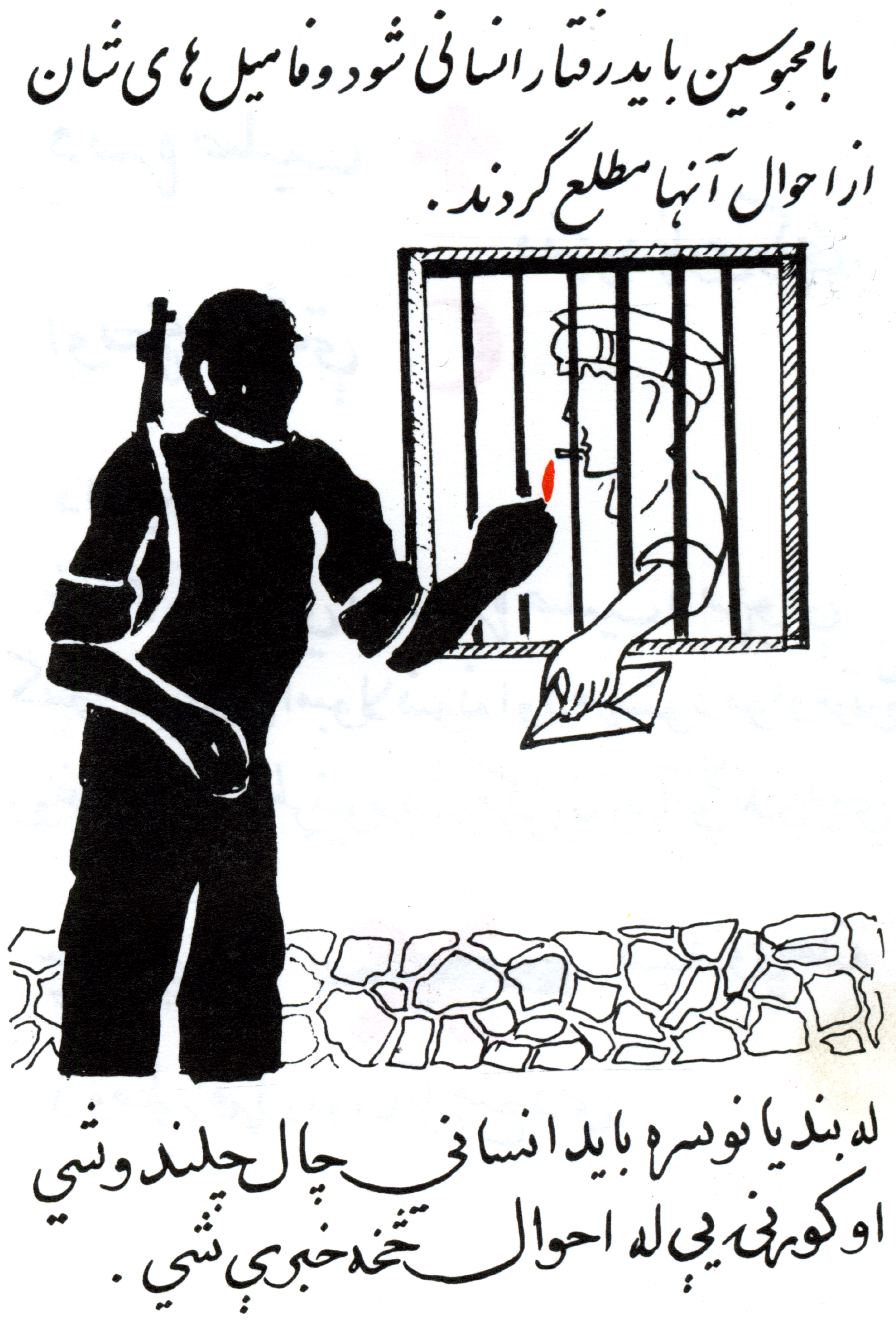




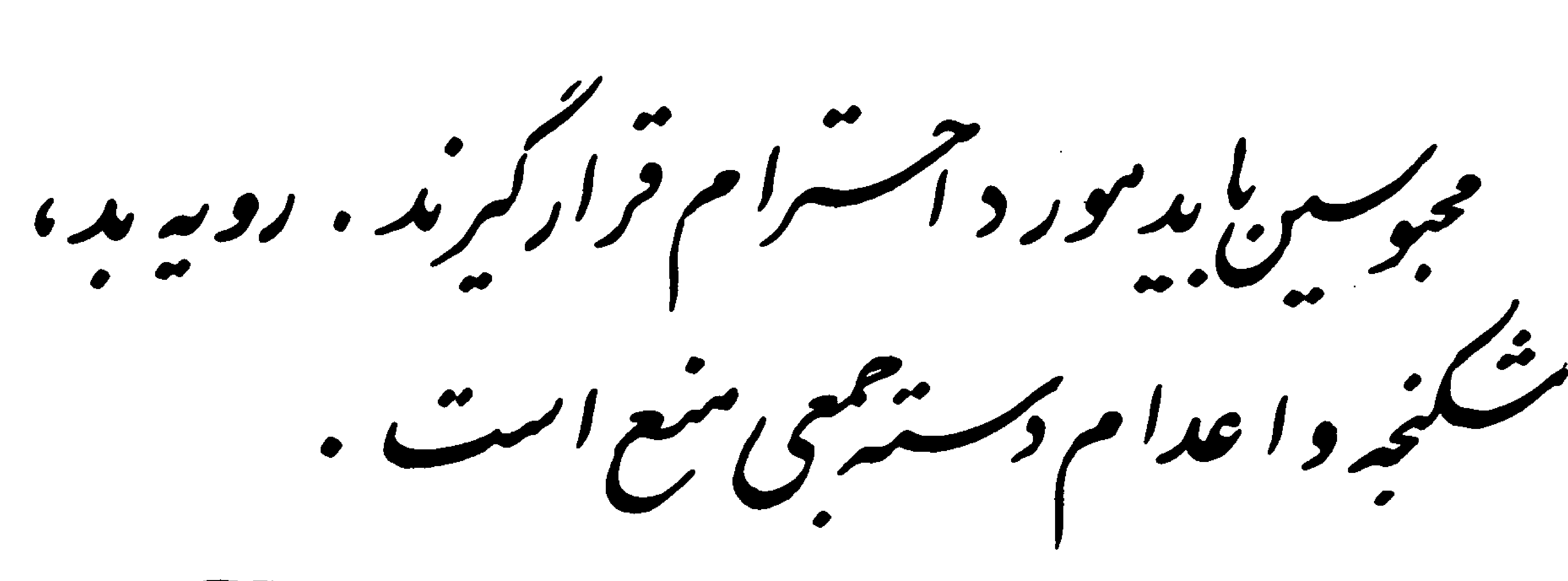

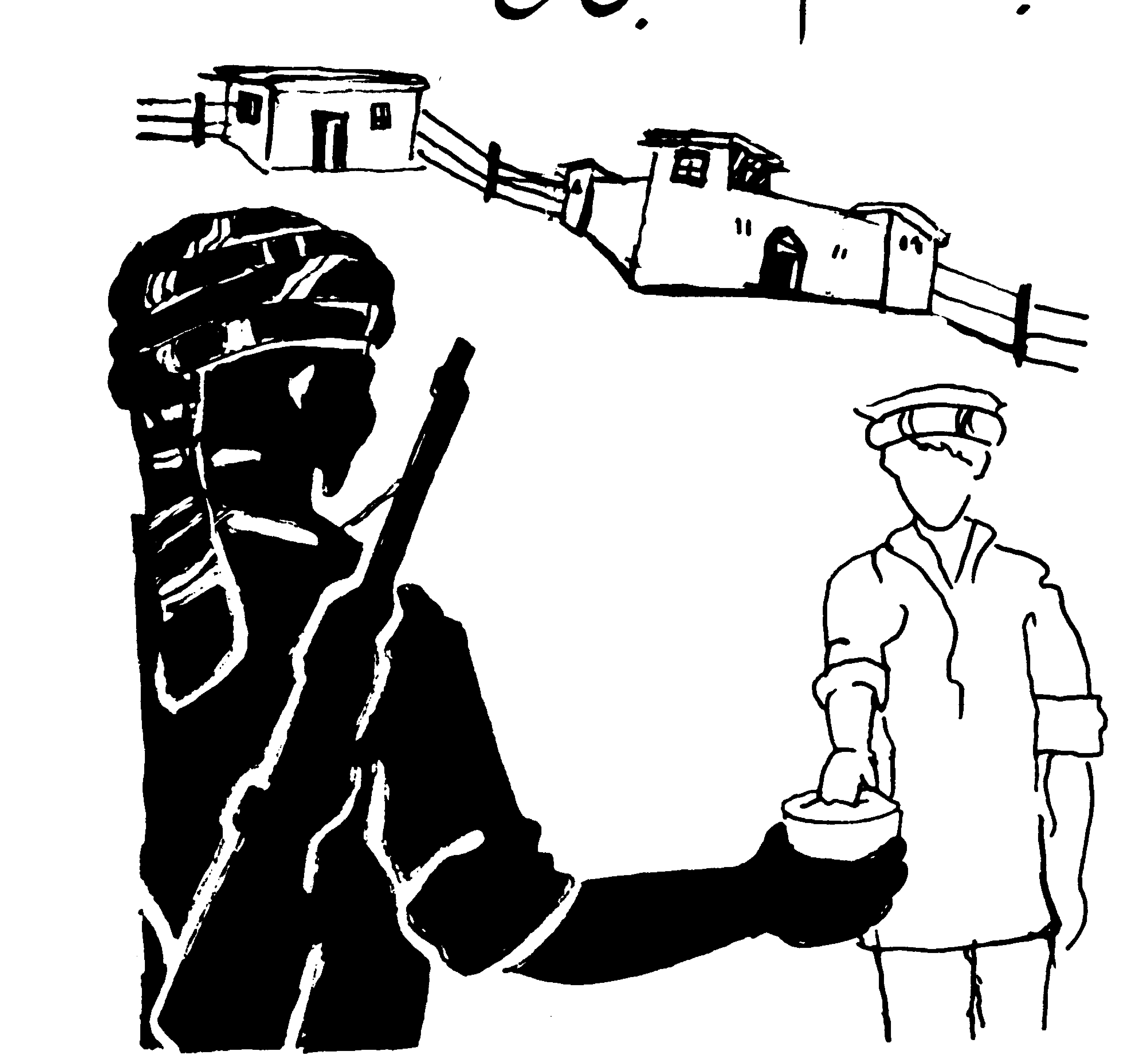

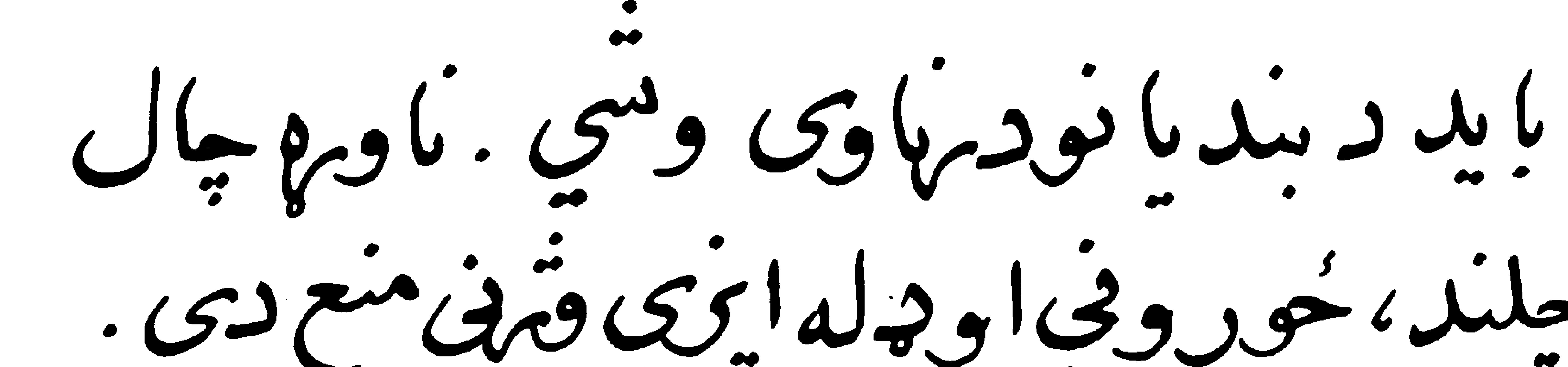




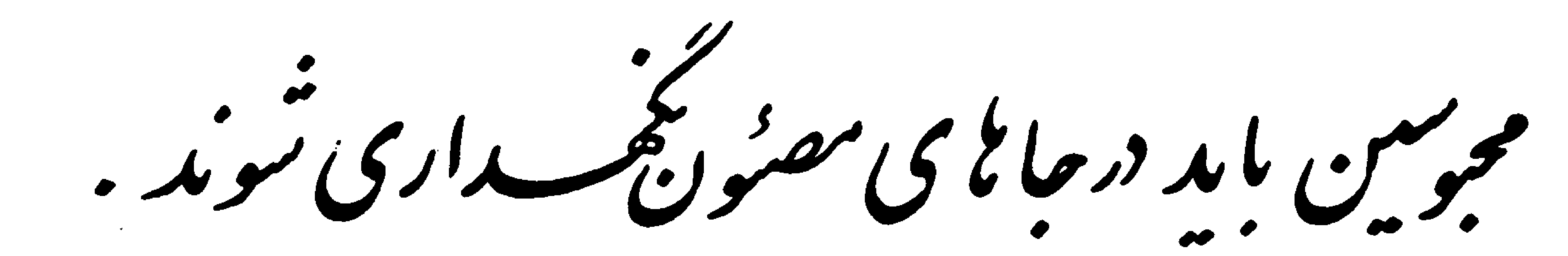
1070

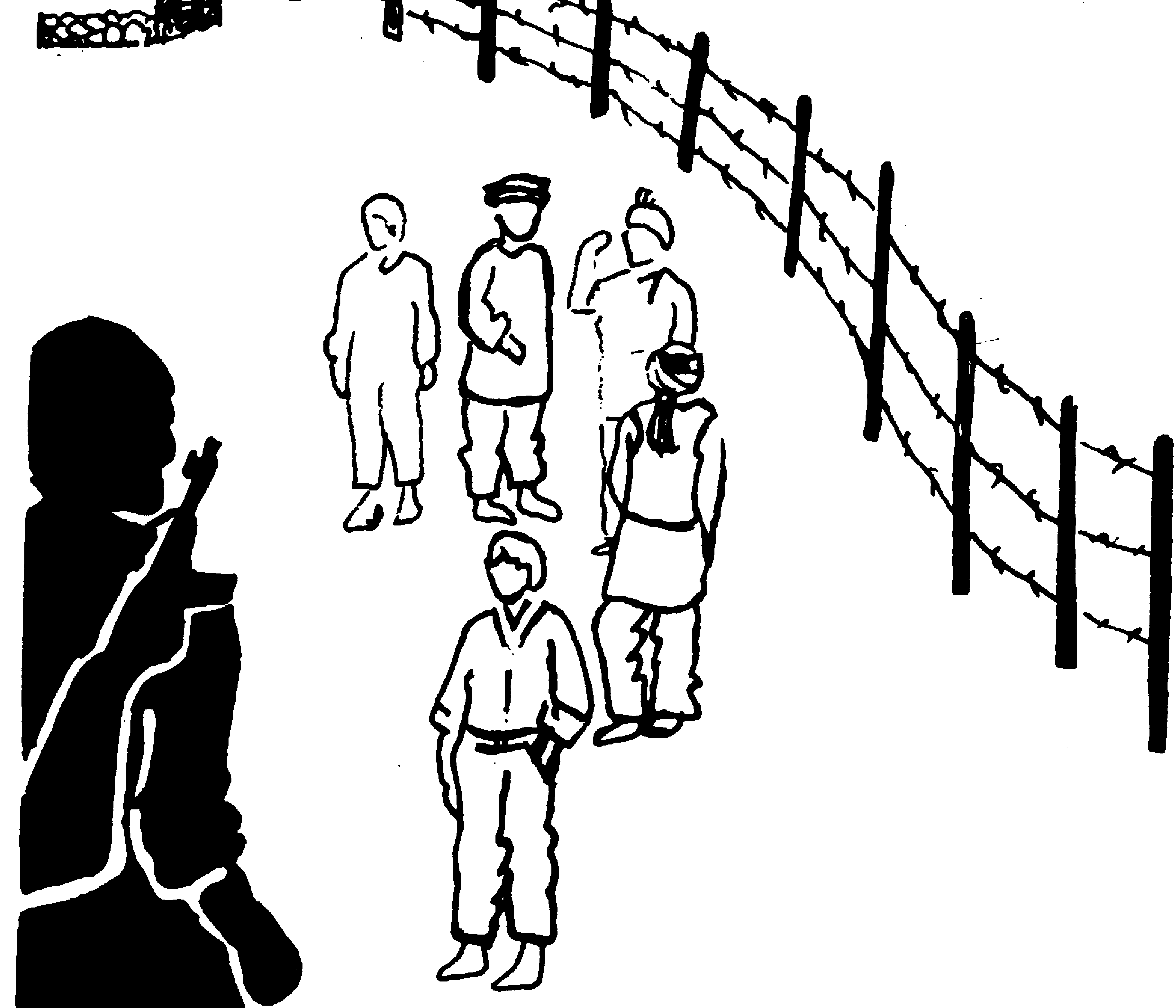

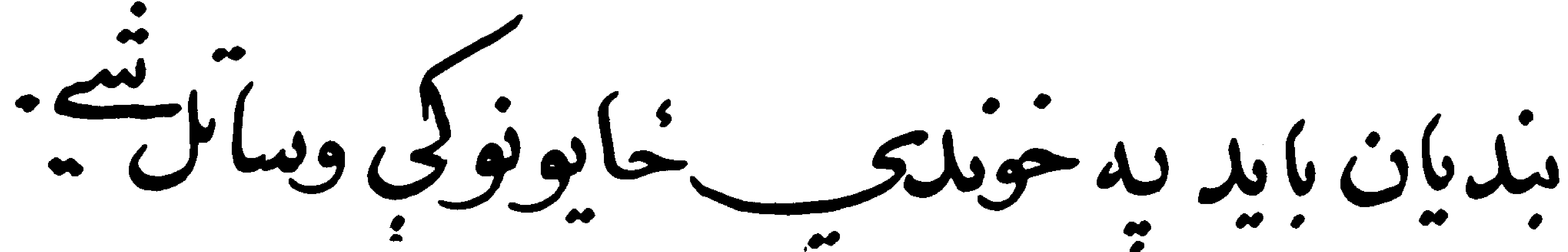
لخطبر دهنوى نخاغكولنغ دي. 


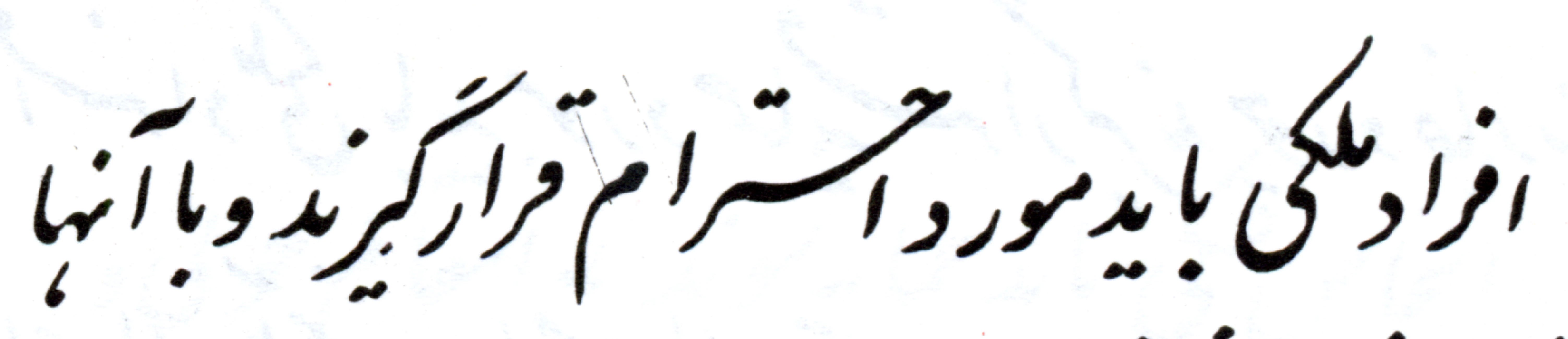

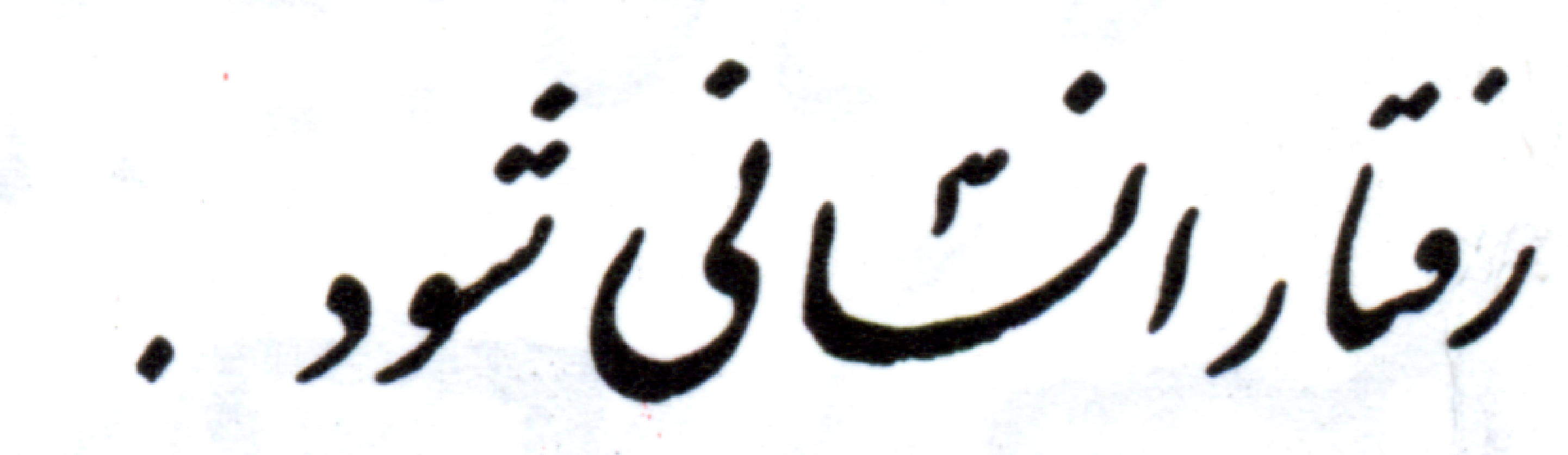

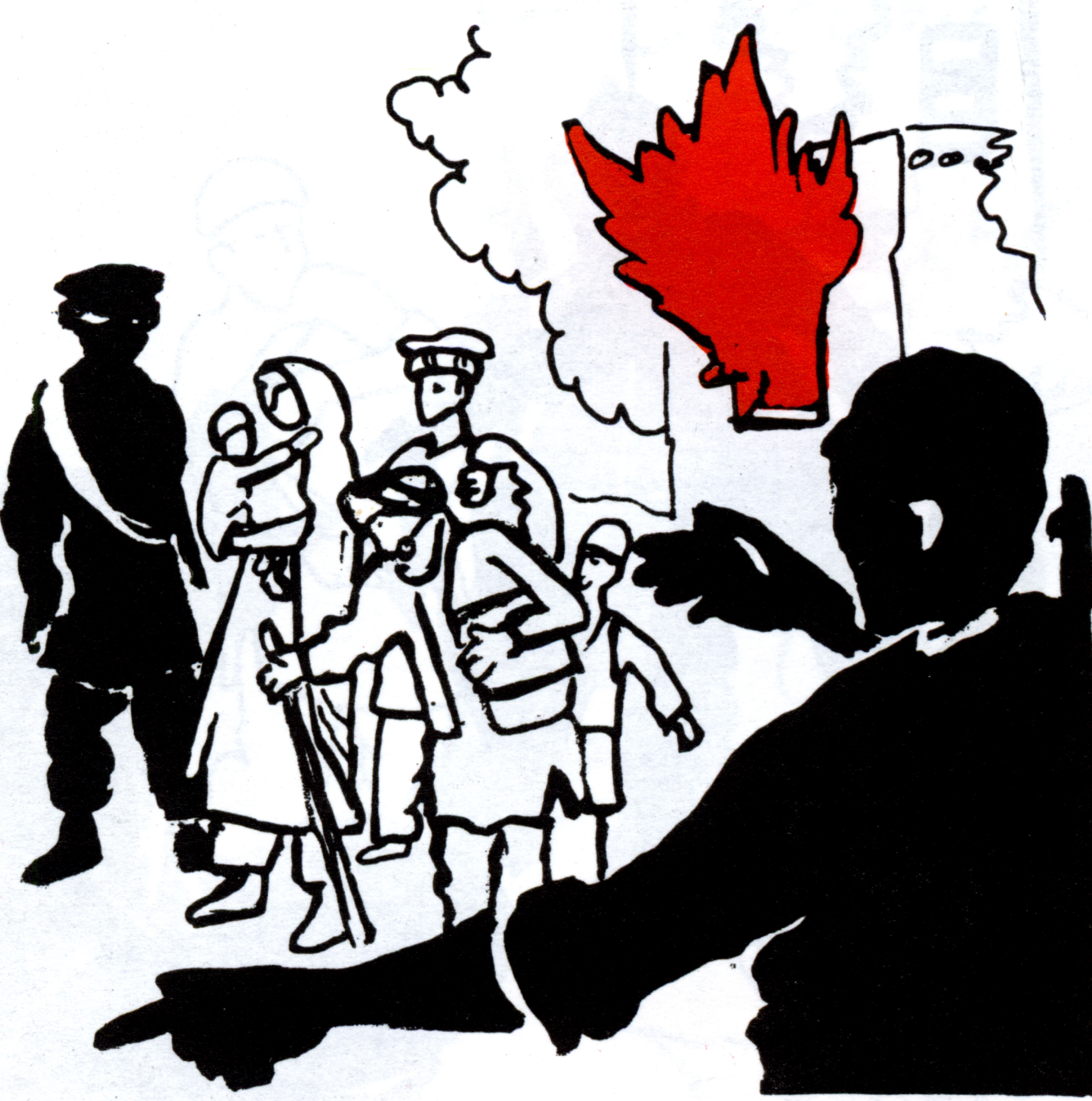

ب يد دملىى خكهودنأوى ولتّى اواذناني

حال جلنا ومهه وفَي . 


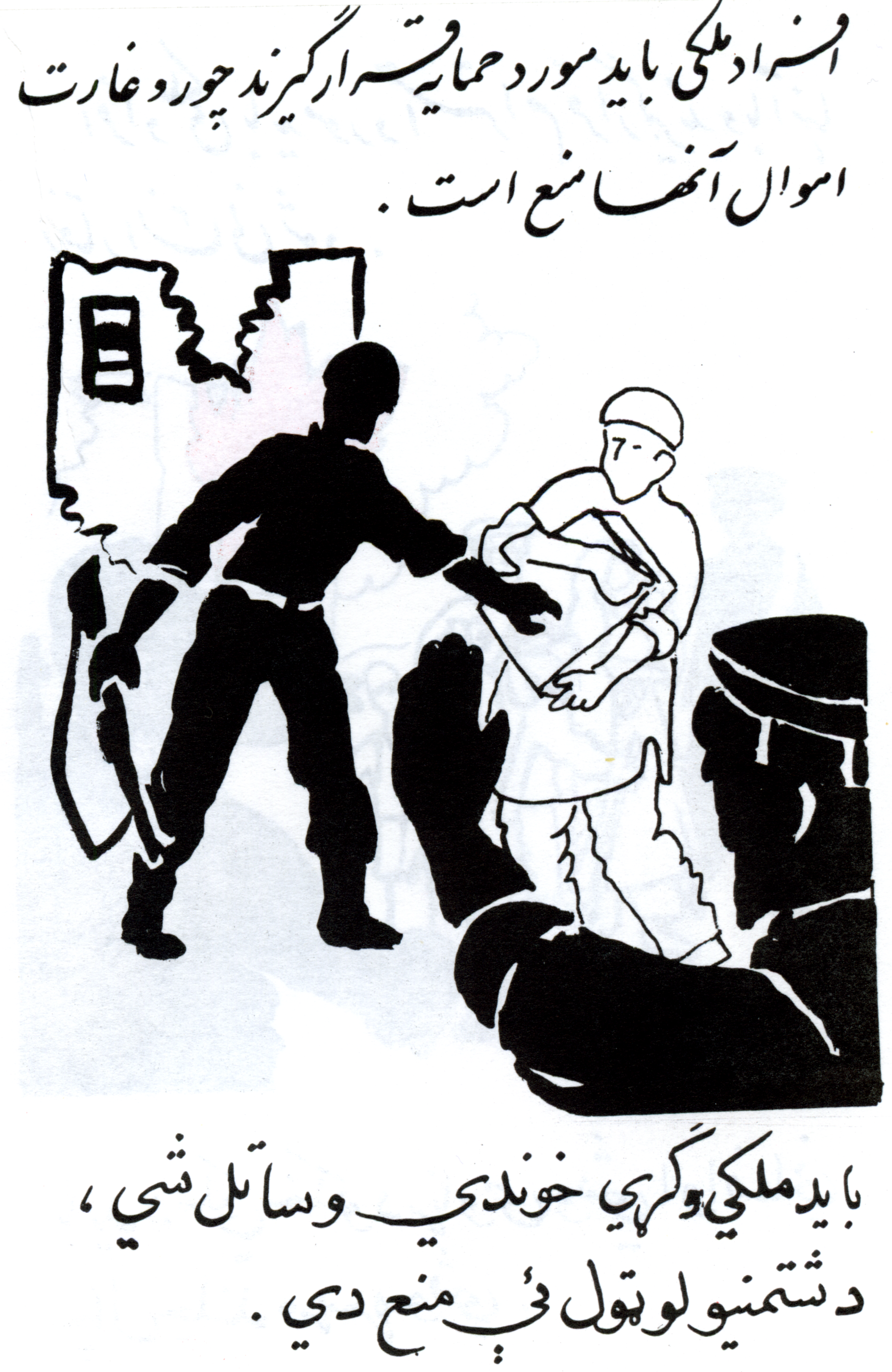





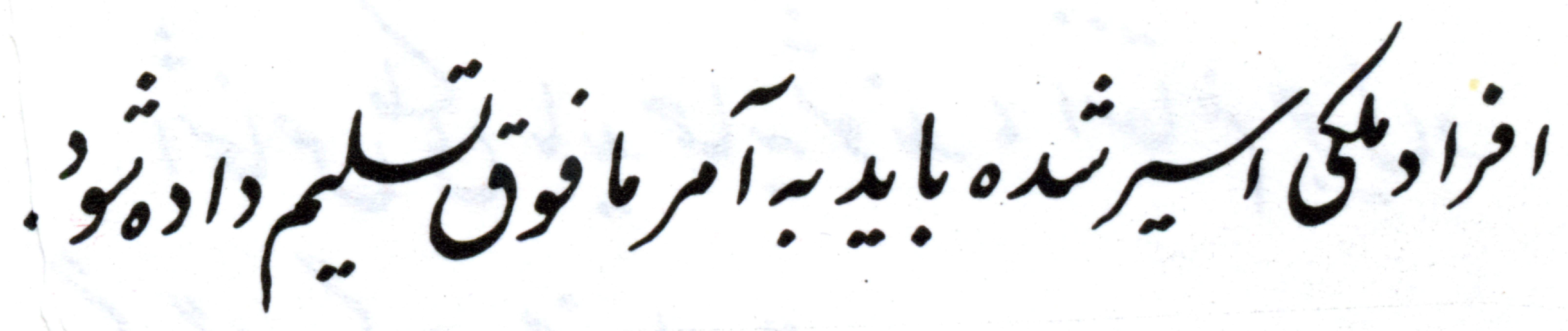

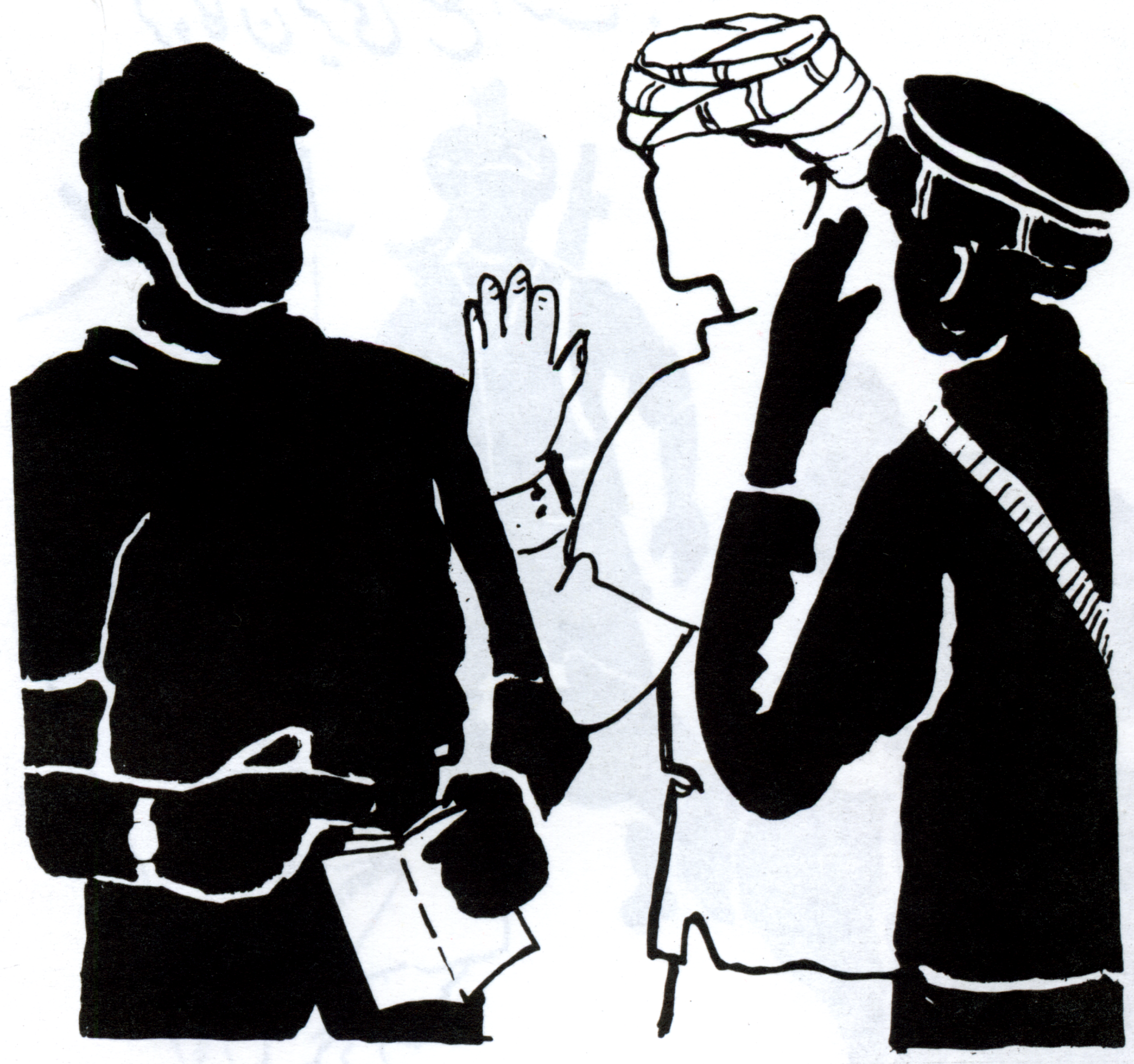

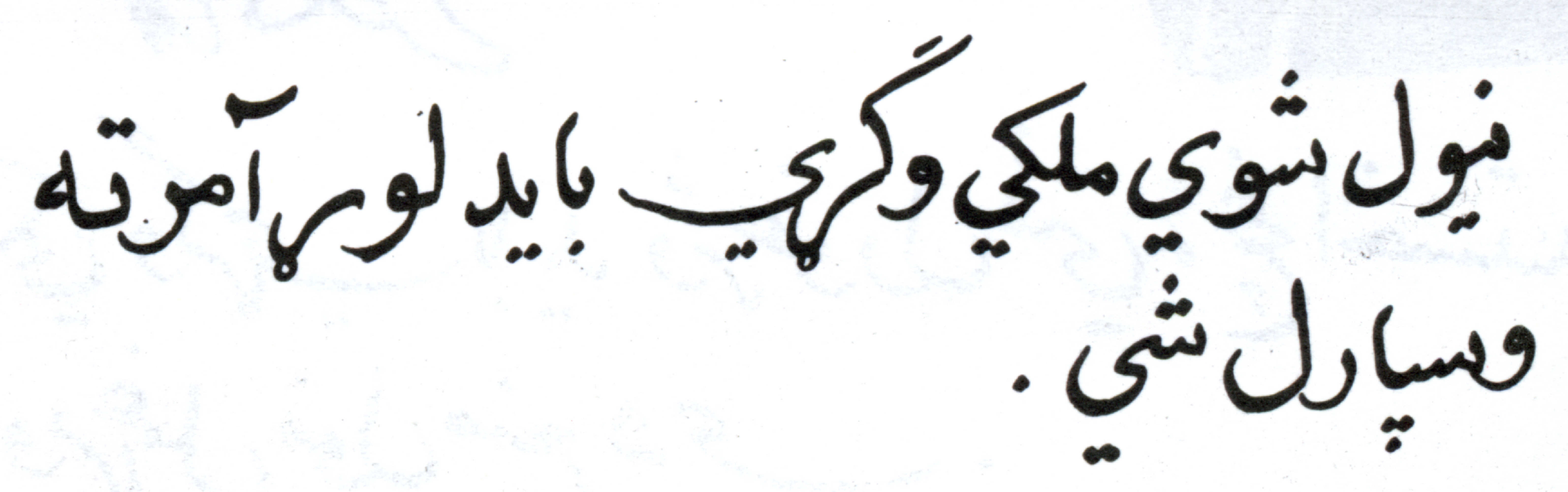




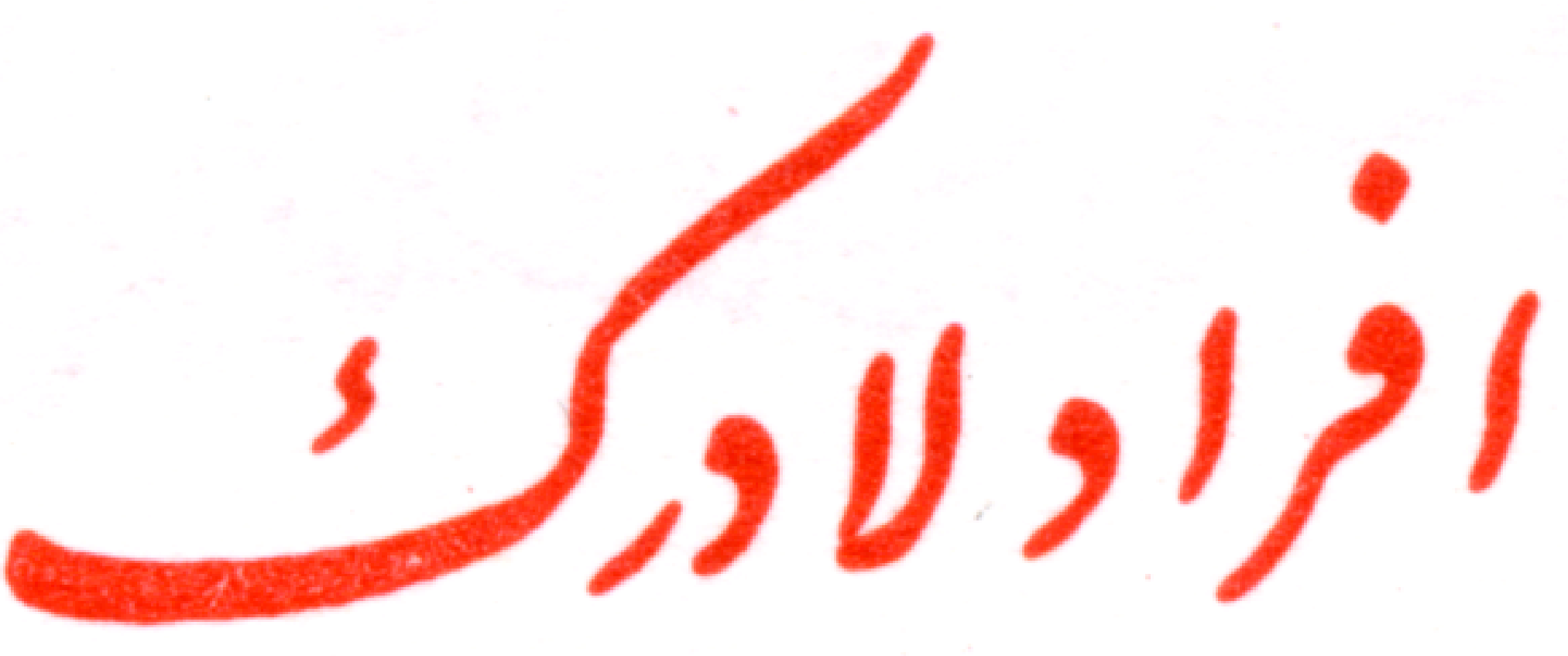

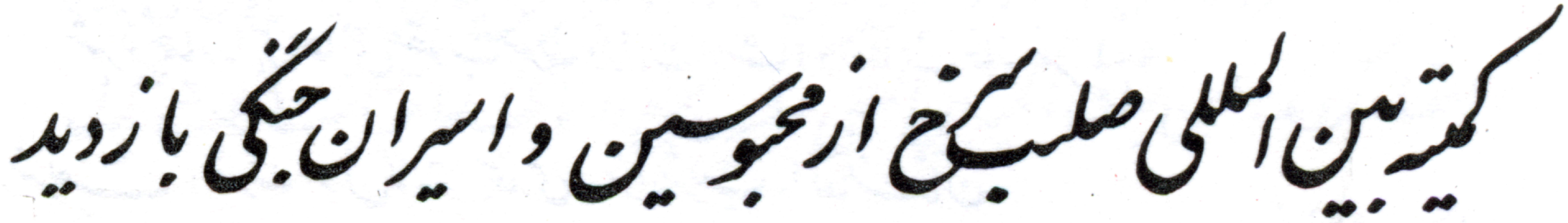

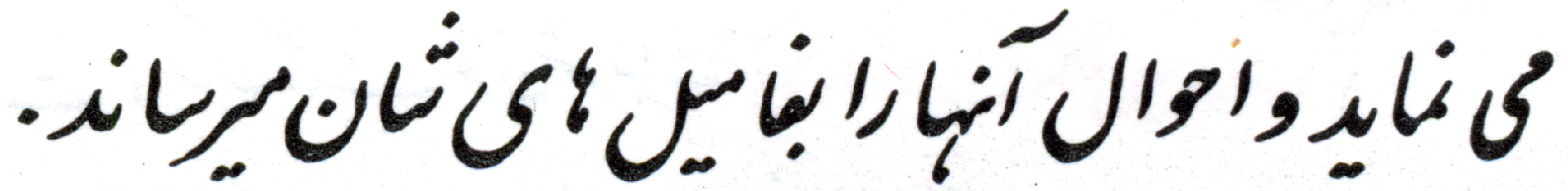
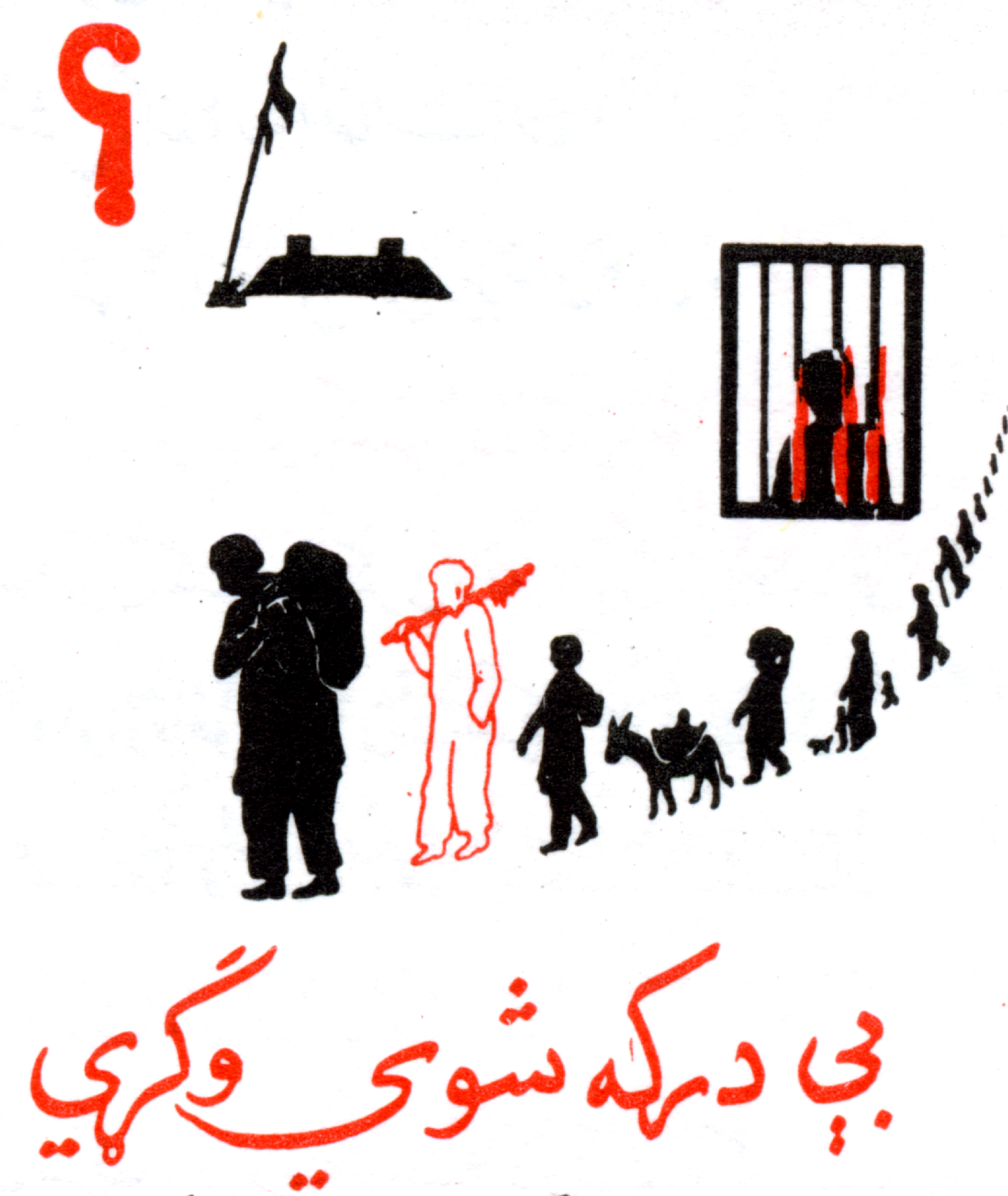

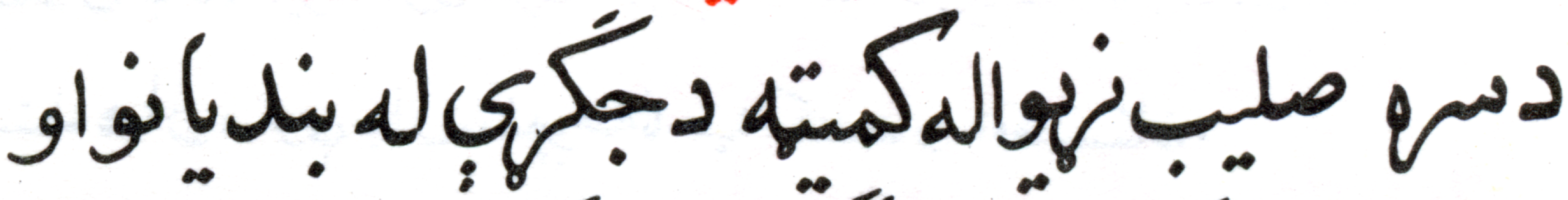

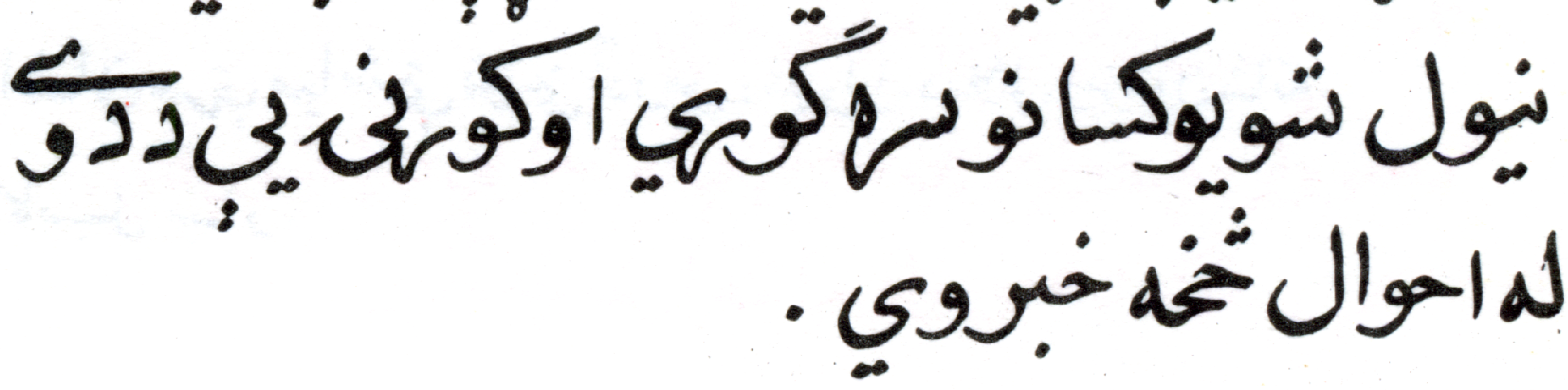


:

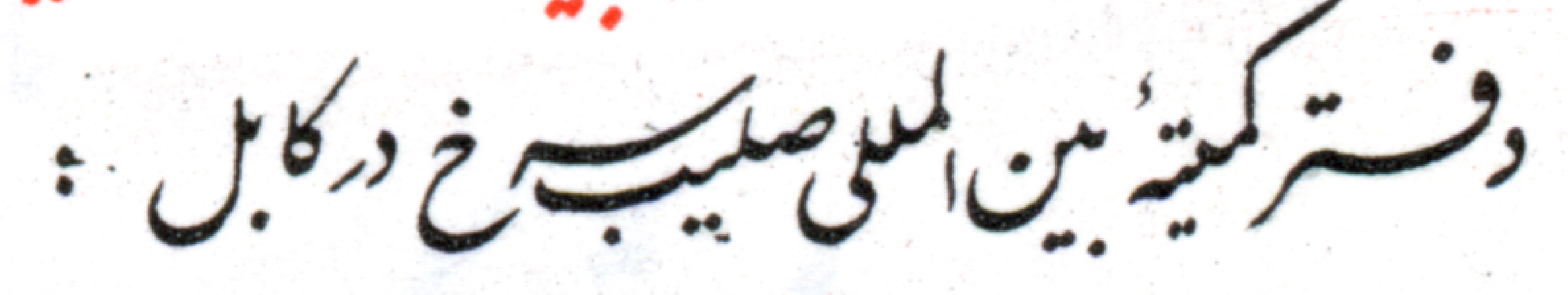

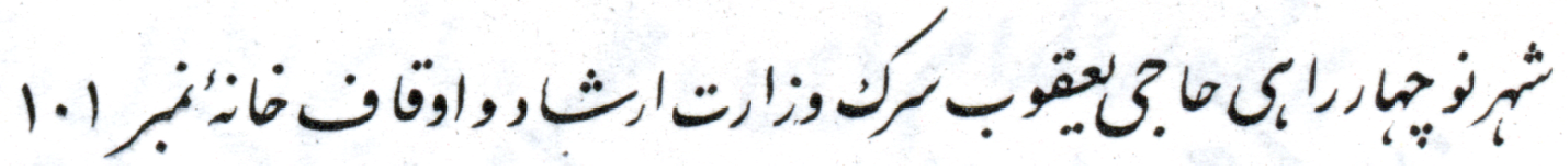

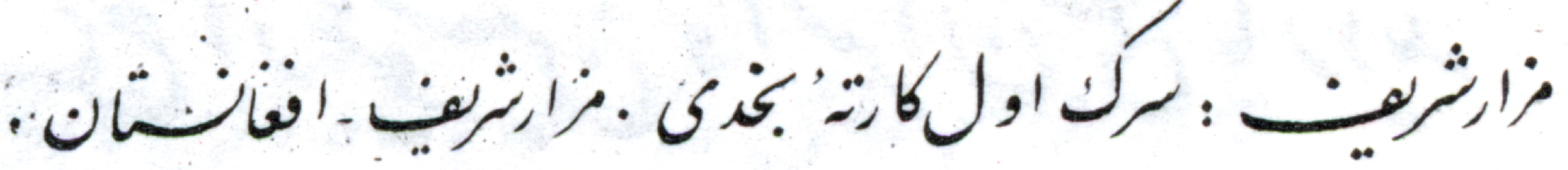

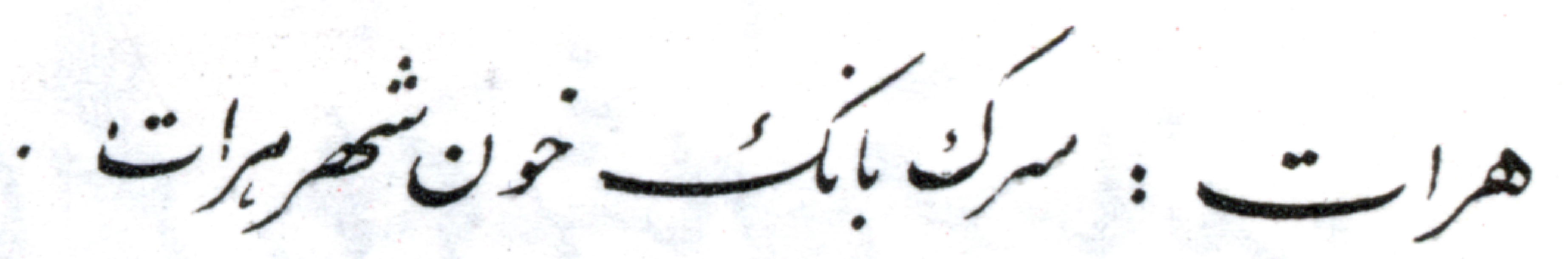

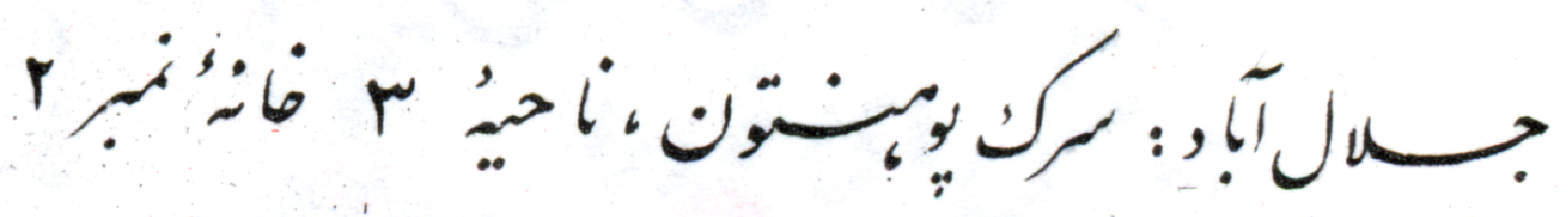

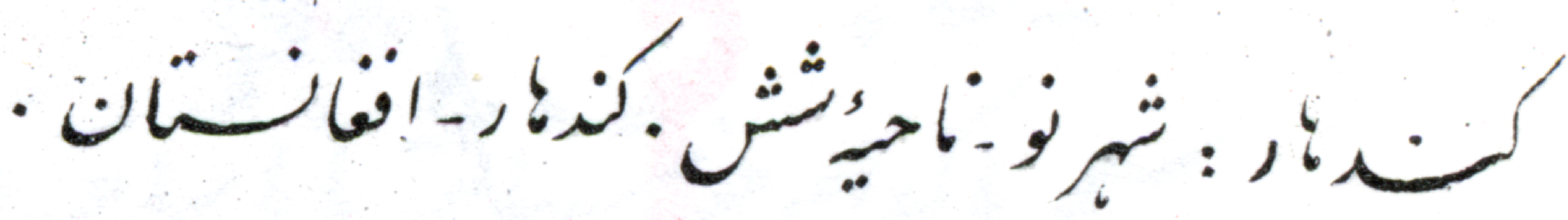

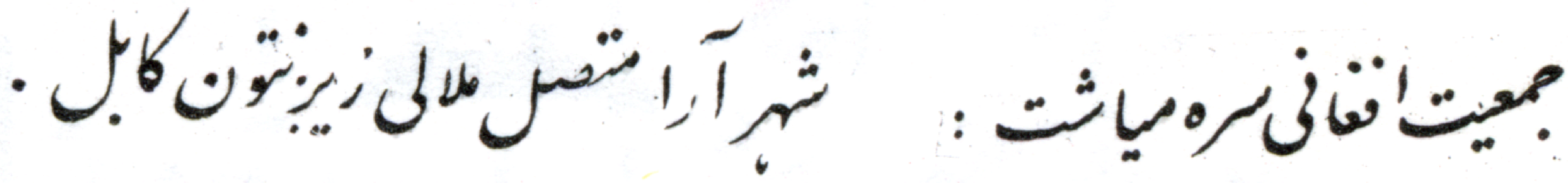

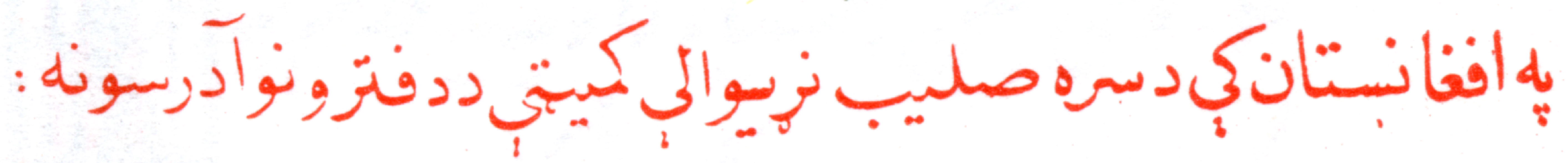

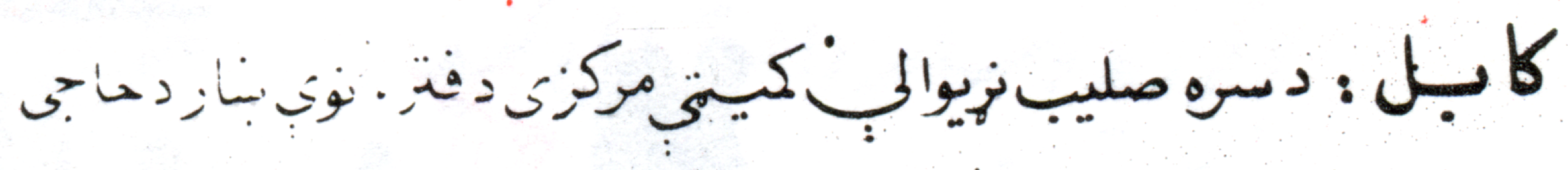

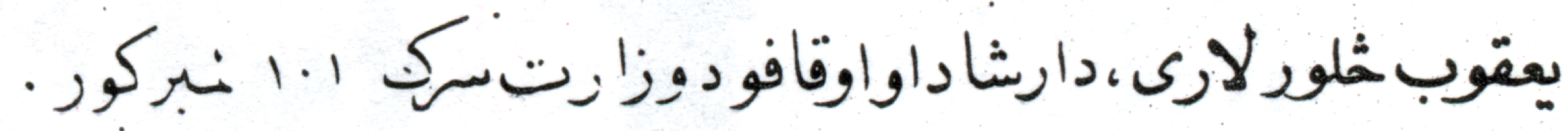

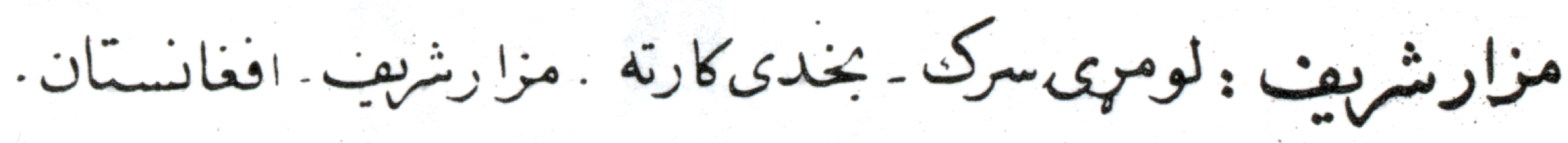
هـرات : دويني دبانك سك ، د هرات بنبار .

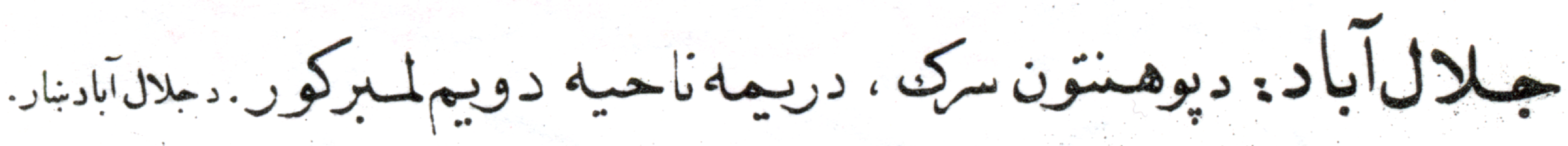

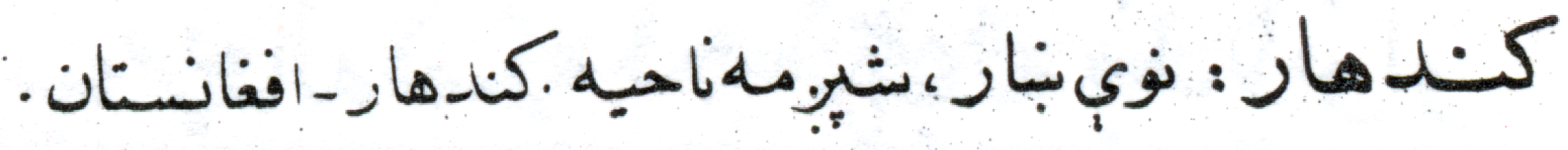

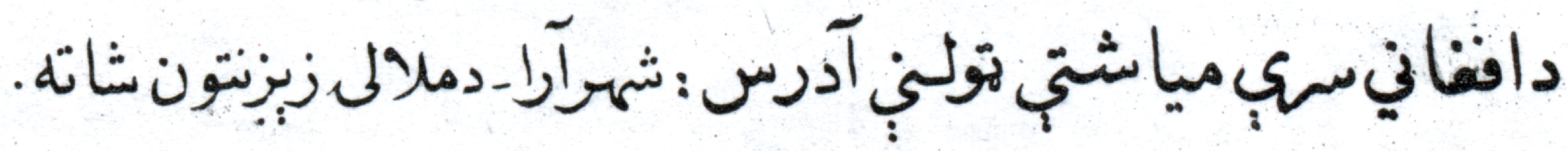
دكابل بنار. 


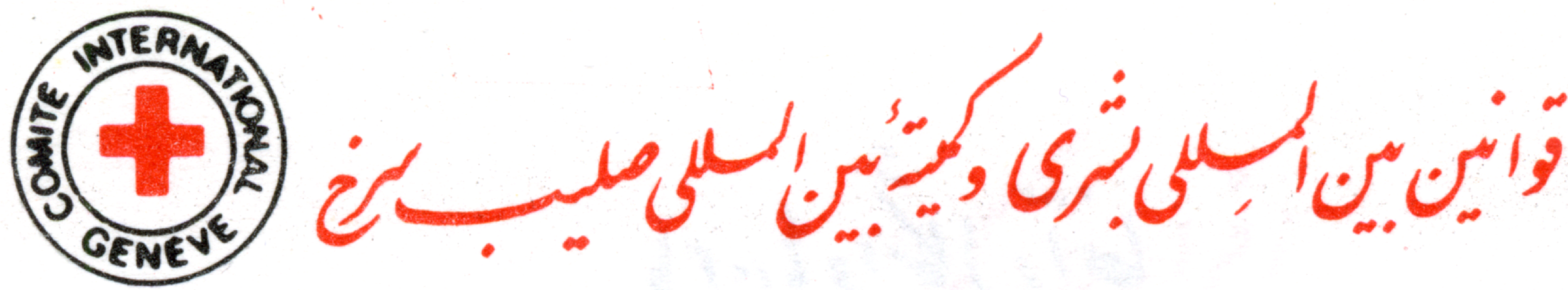

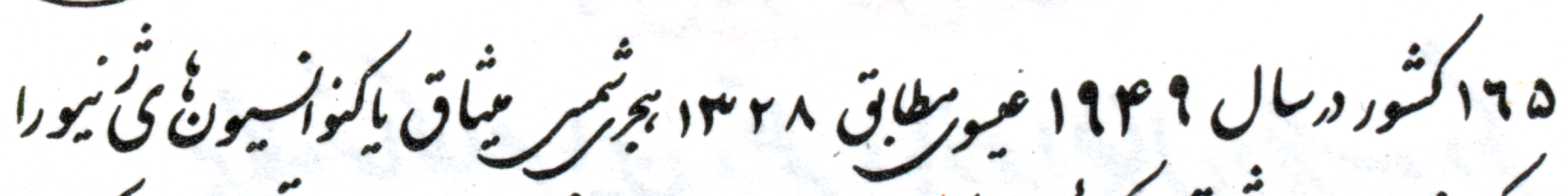

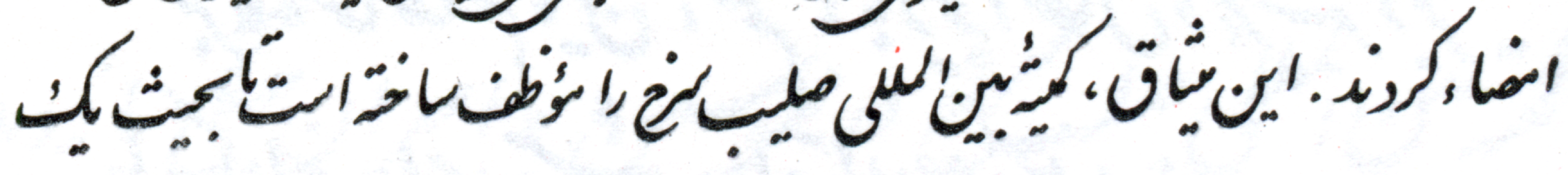

$$
\begin{aligned}
& 8>_{\infty}^{\circ}
\end{aligned}
$$

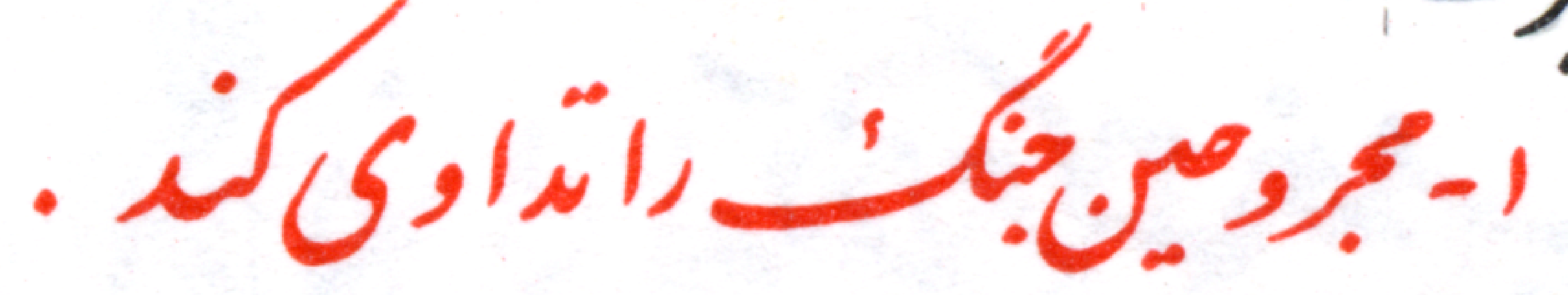

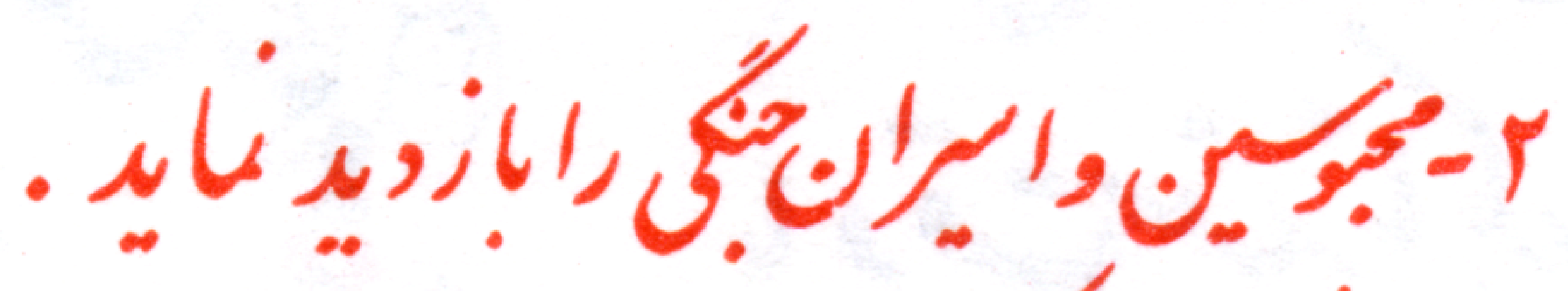

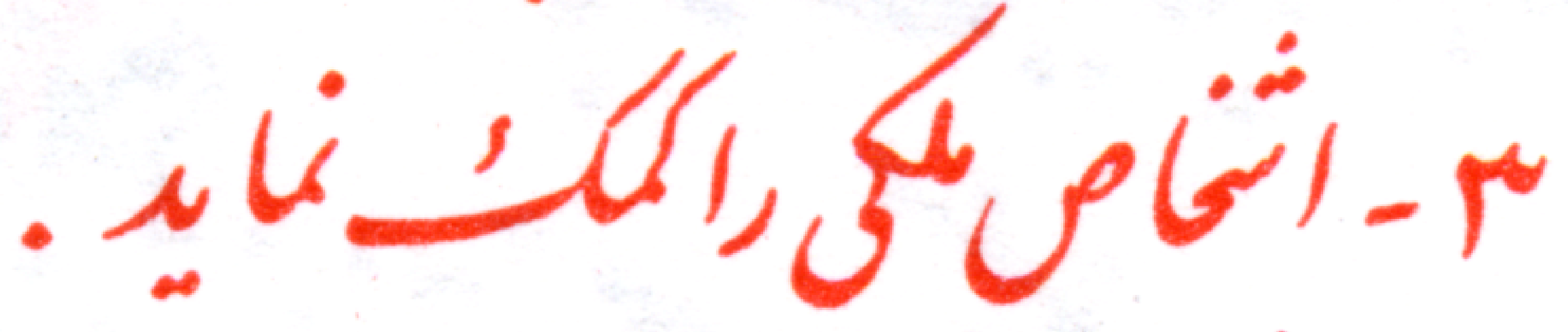

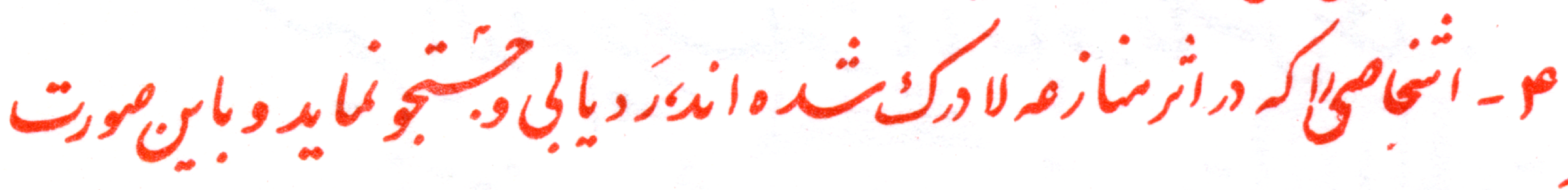

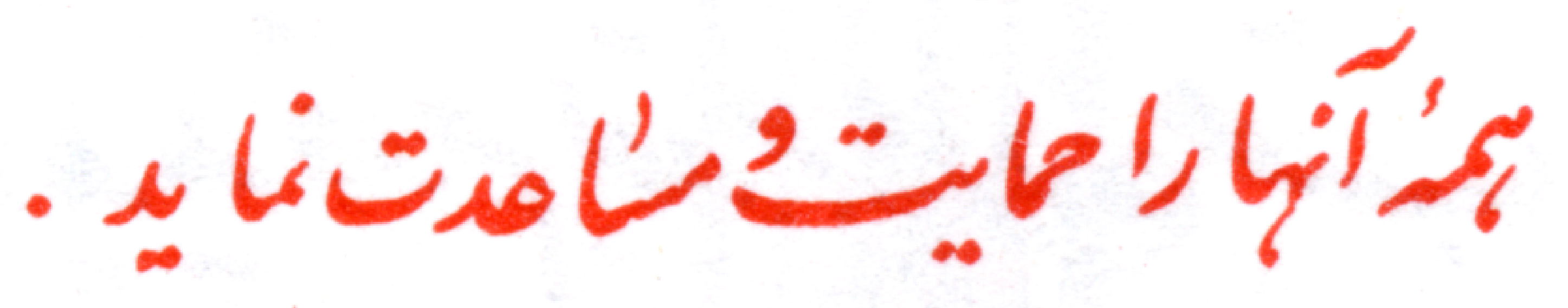

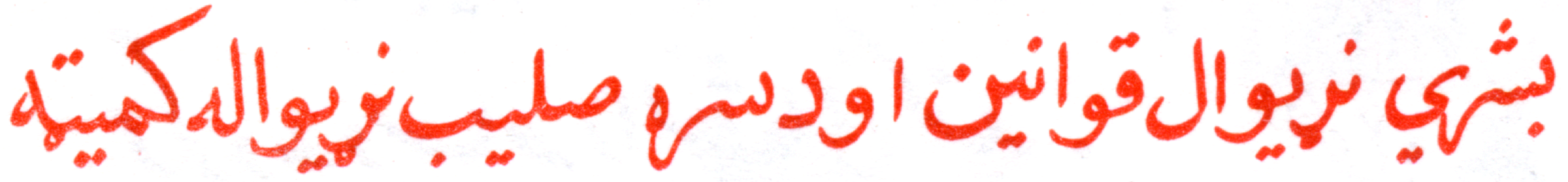

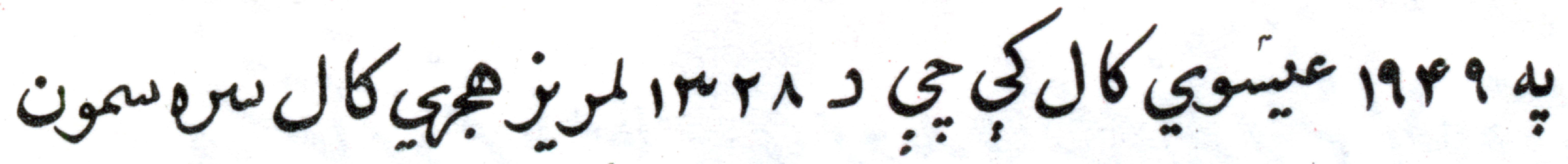

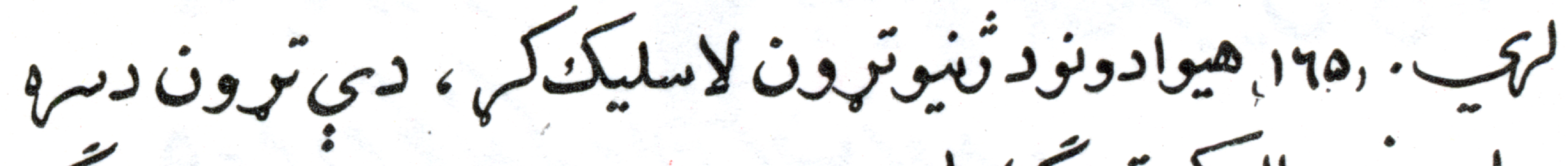

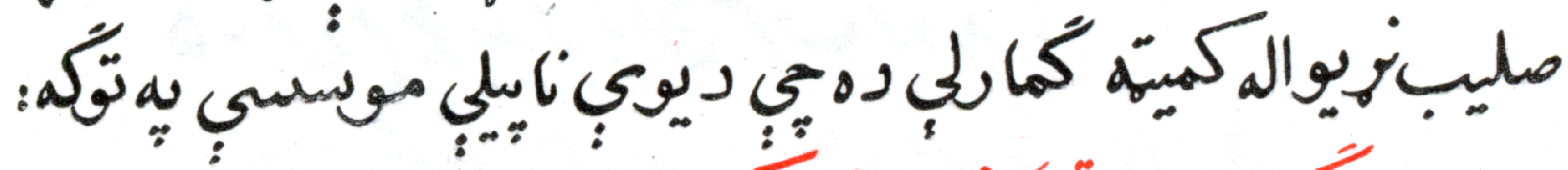

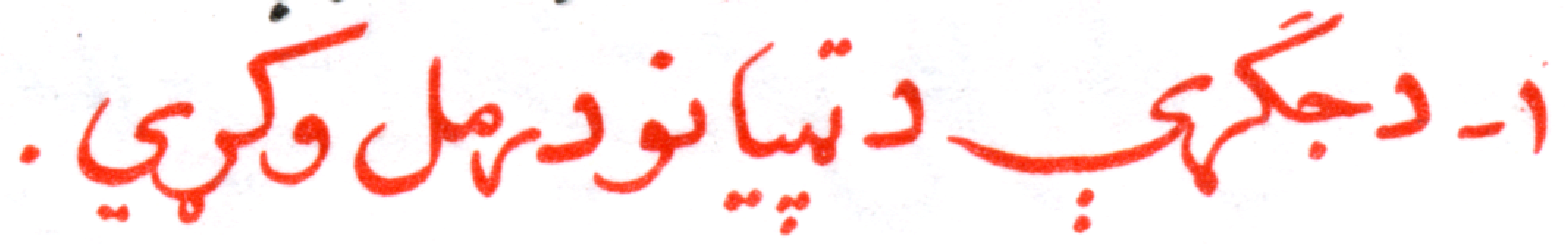

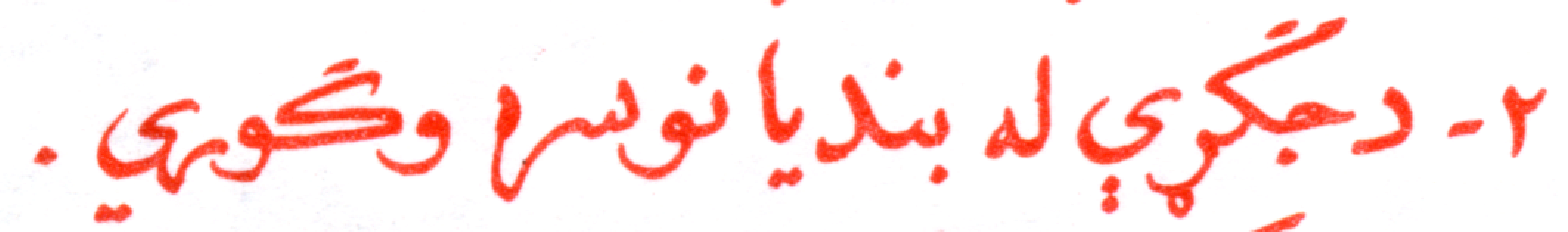

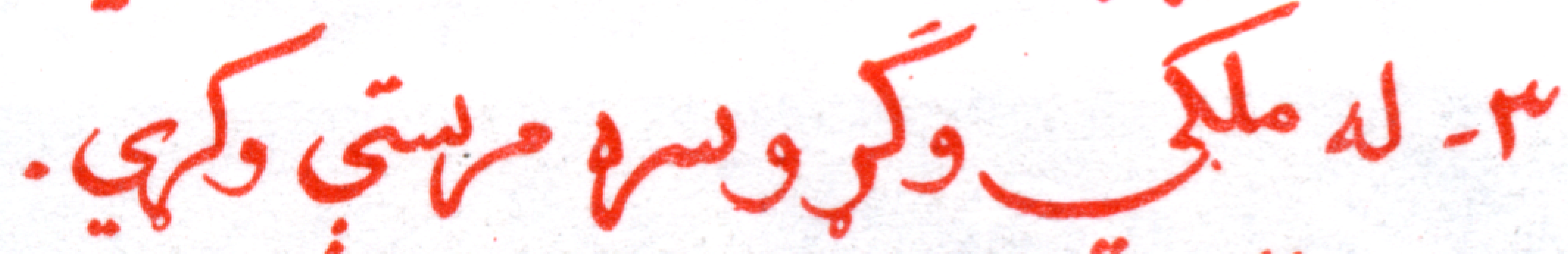

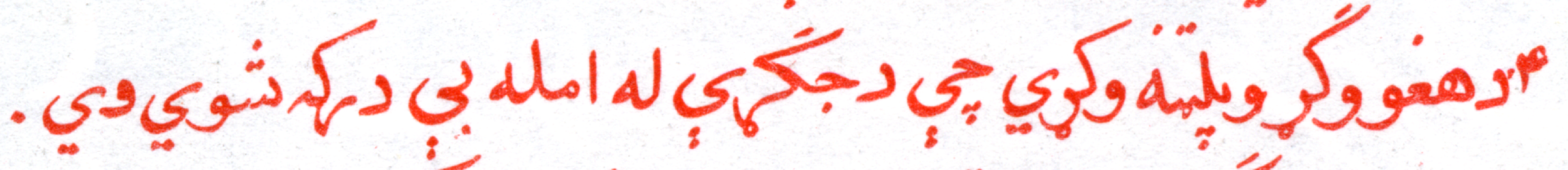

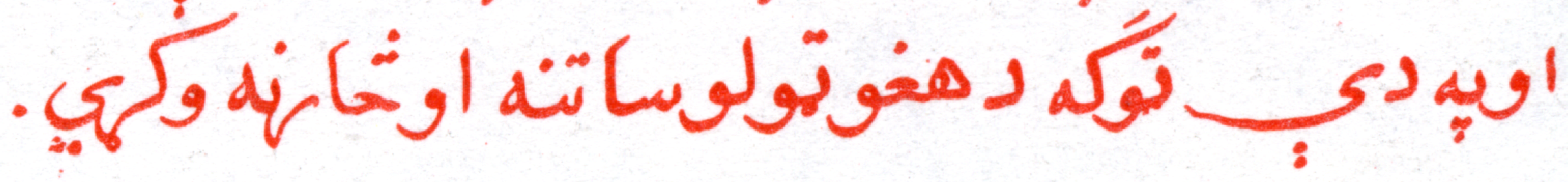




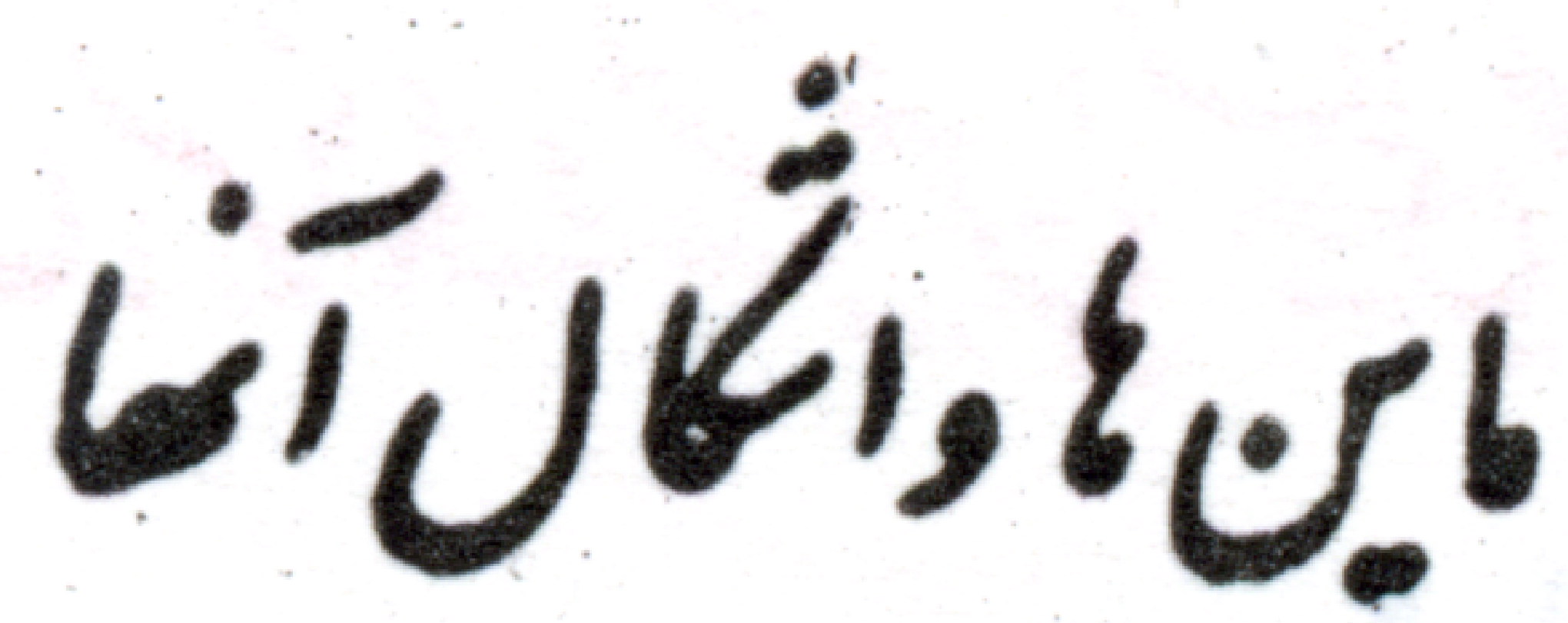

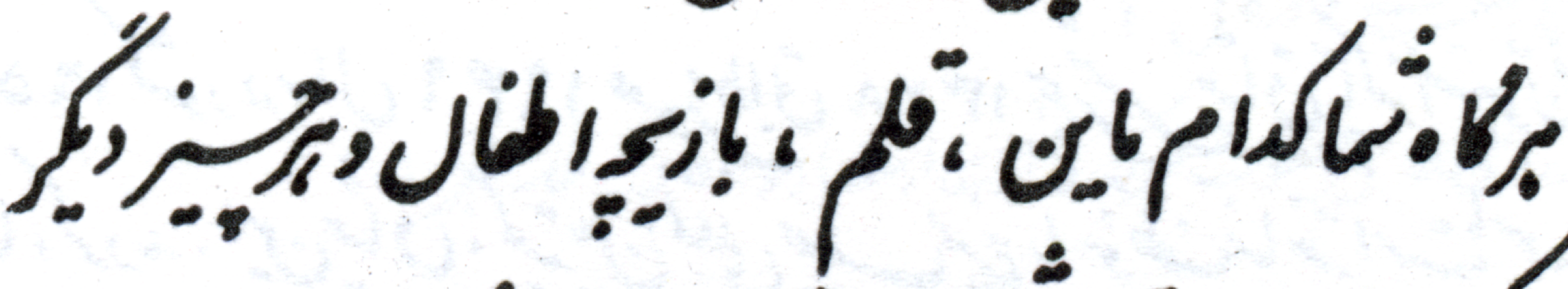

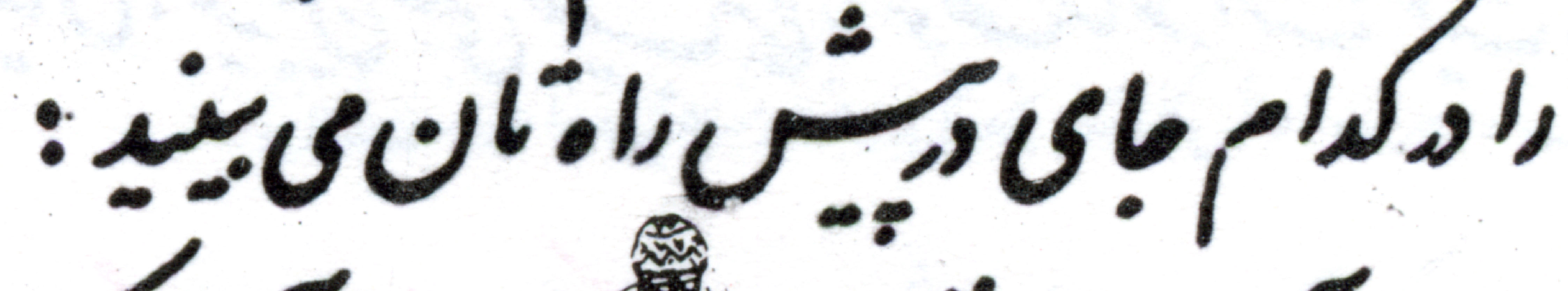

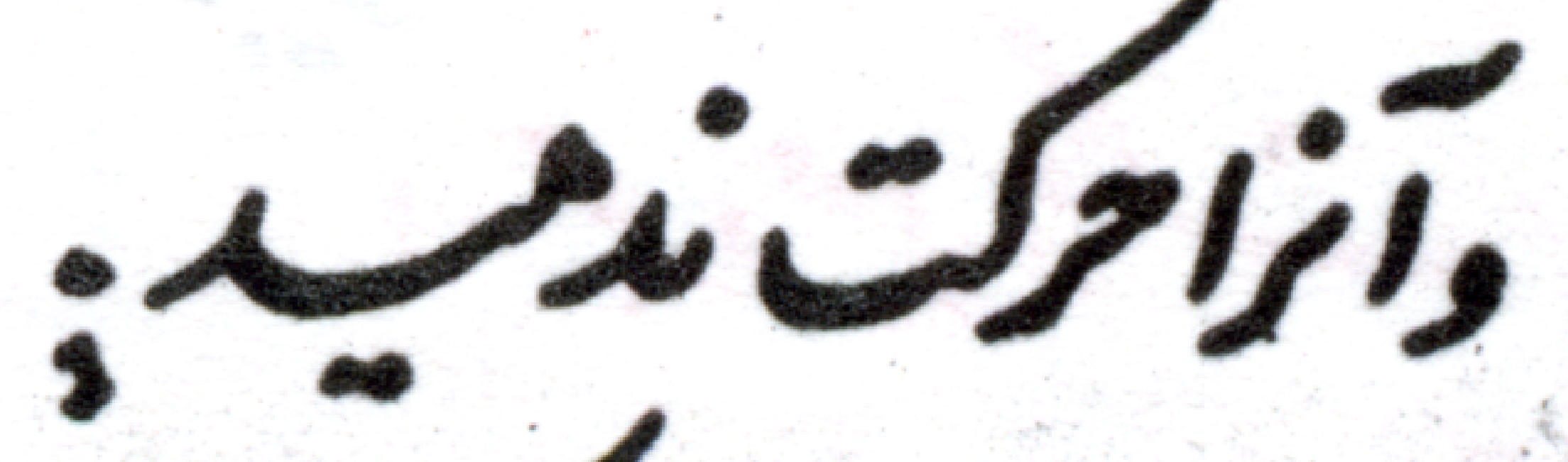

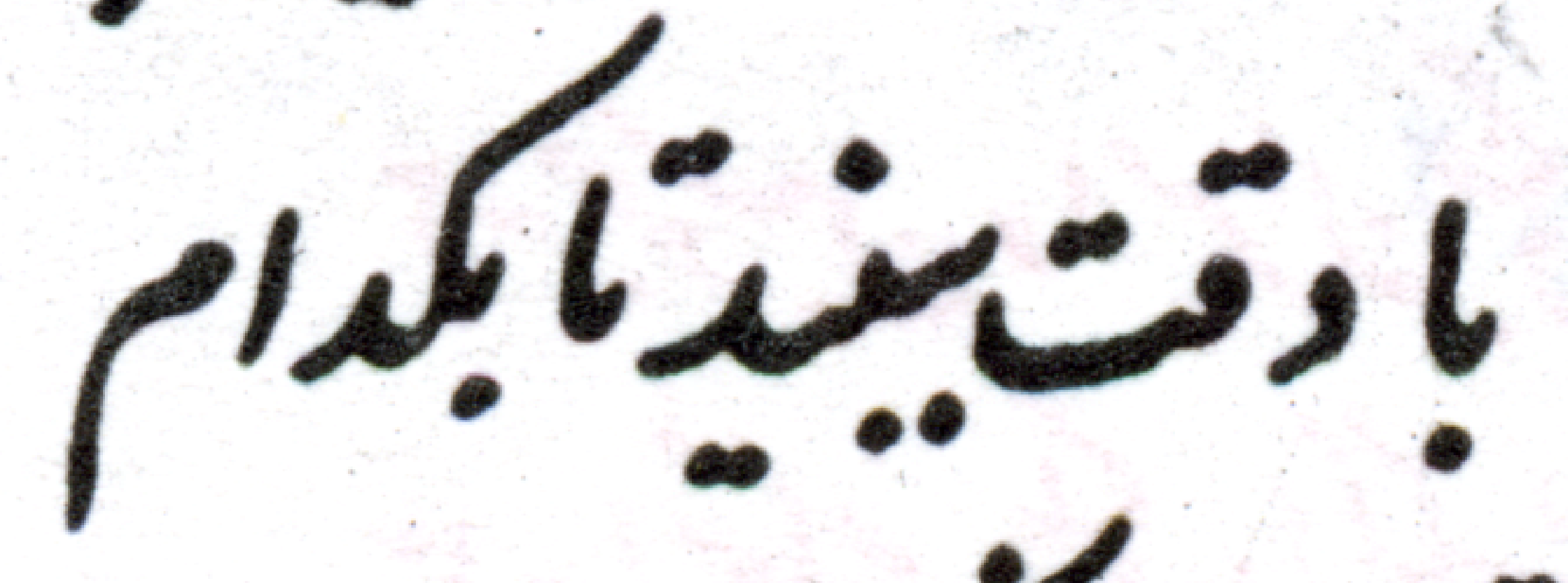

1)

.

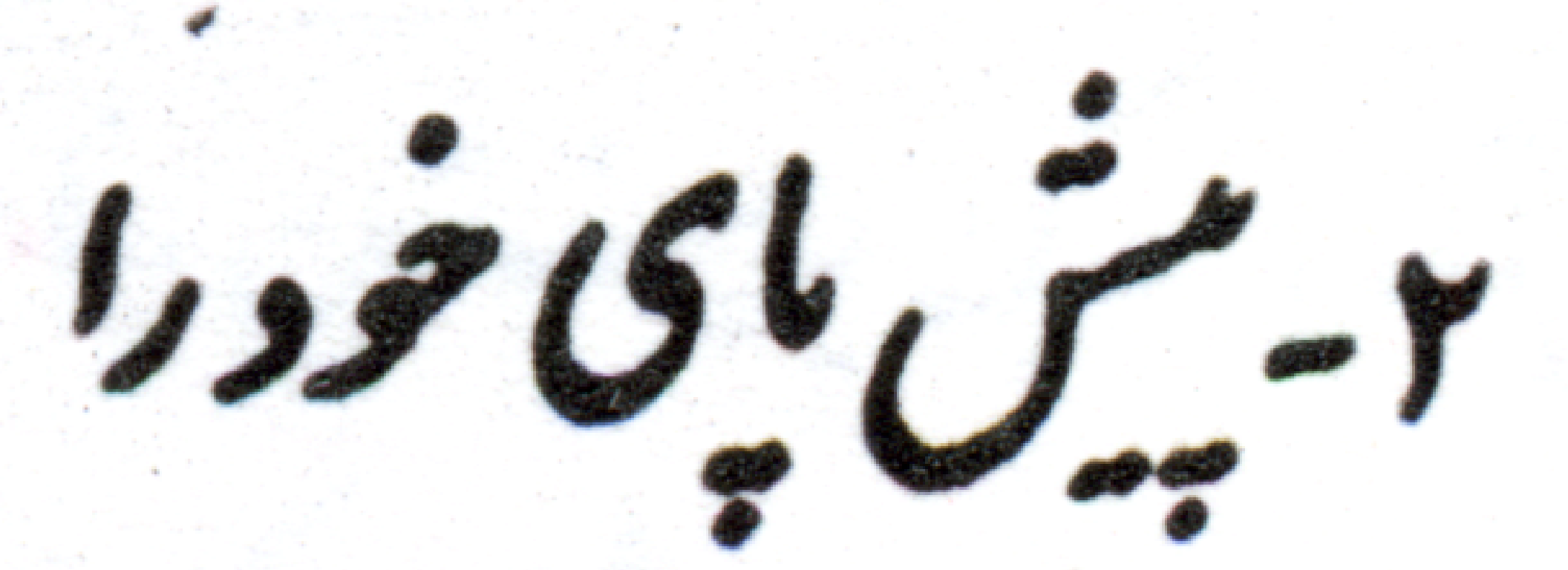

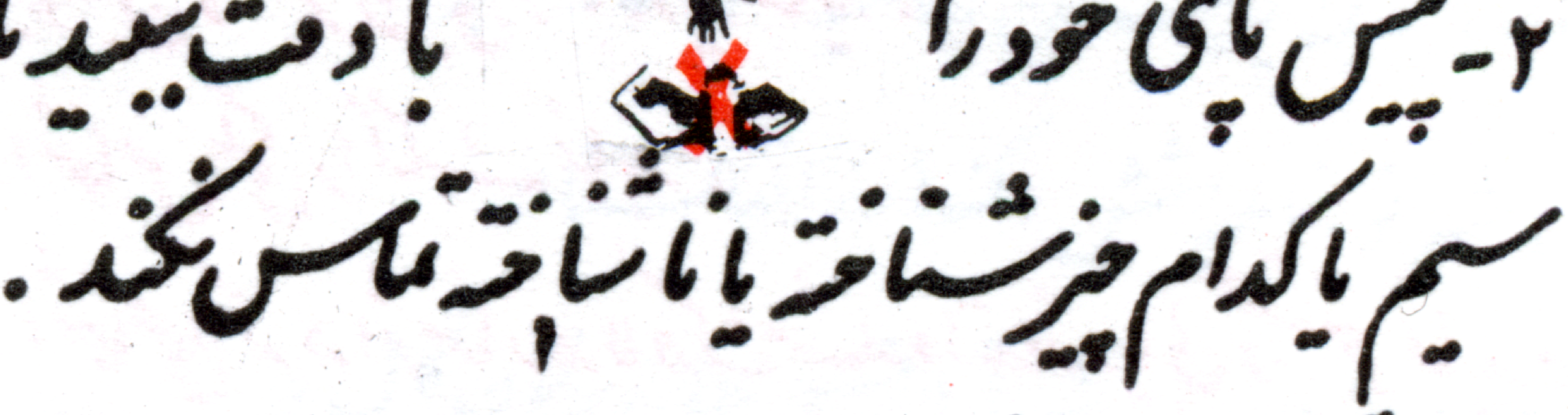

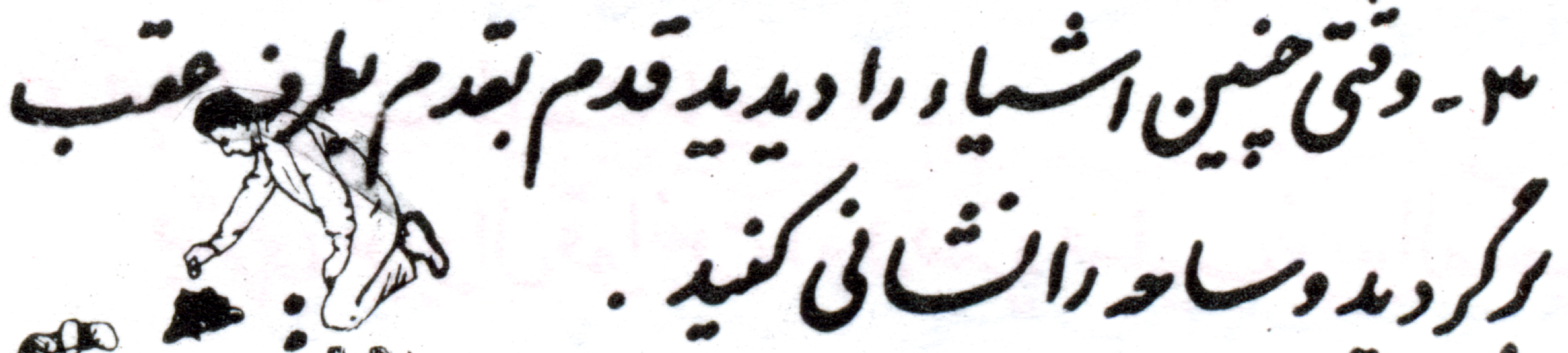

$-0$

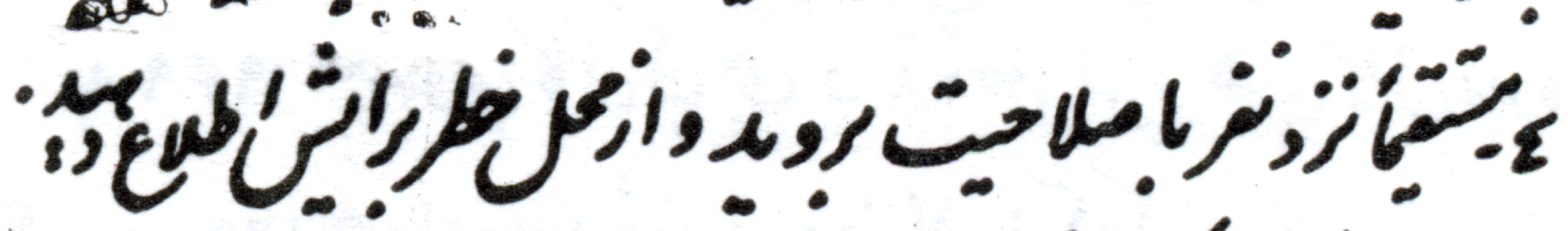

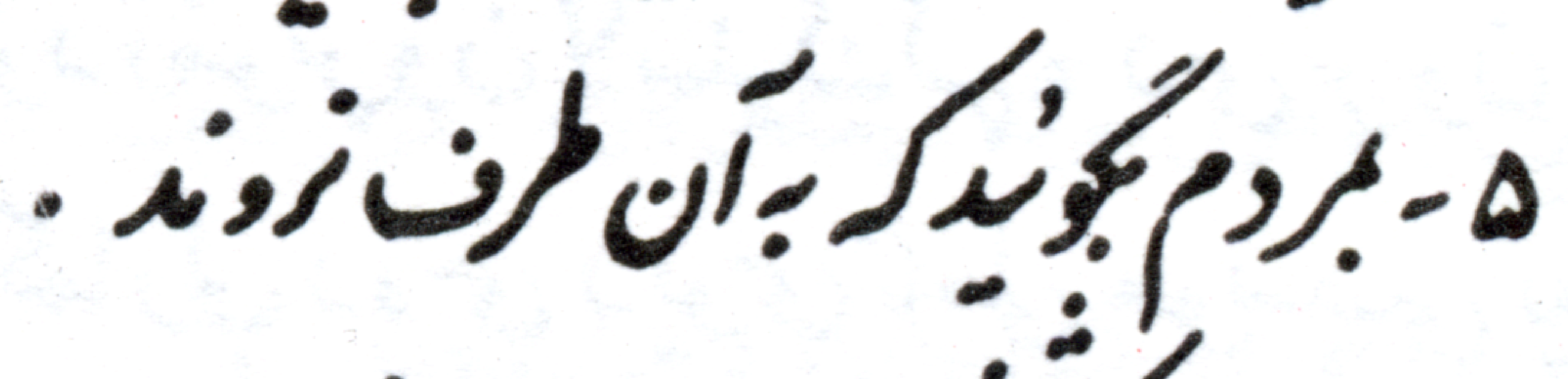

ا

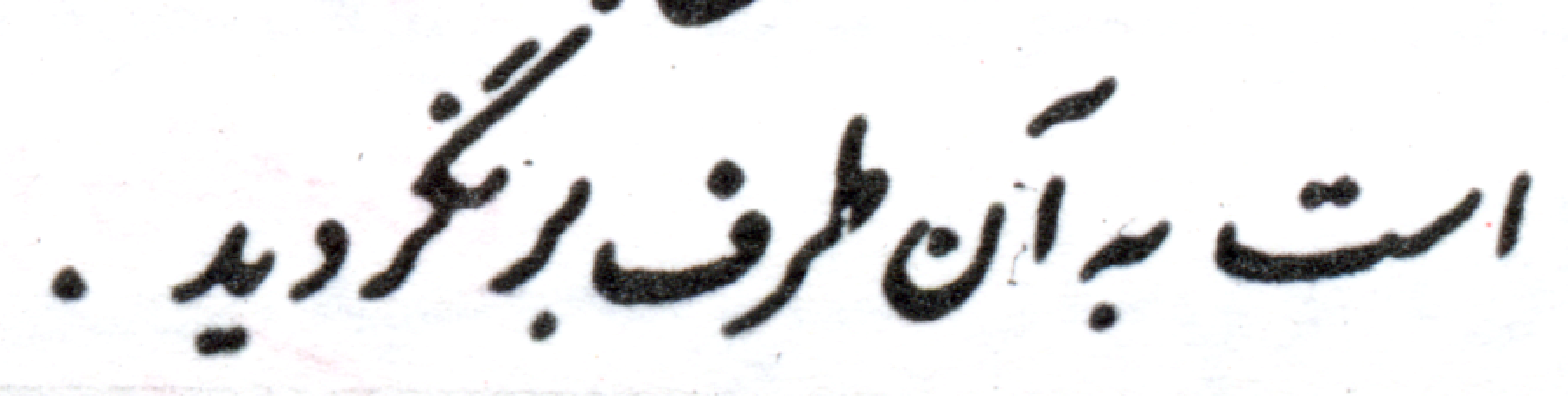




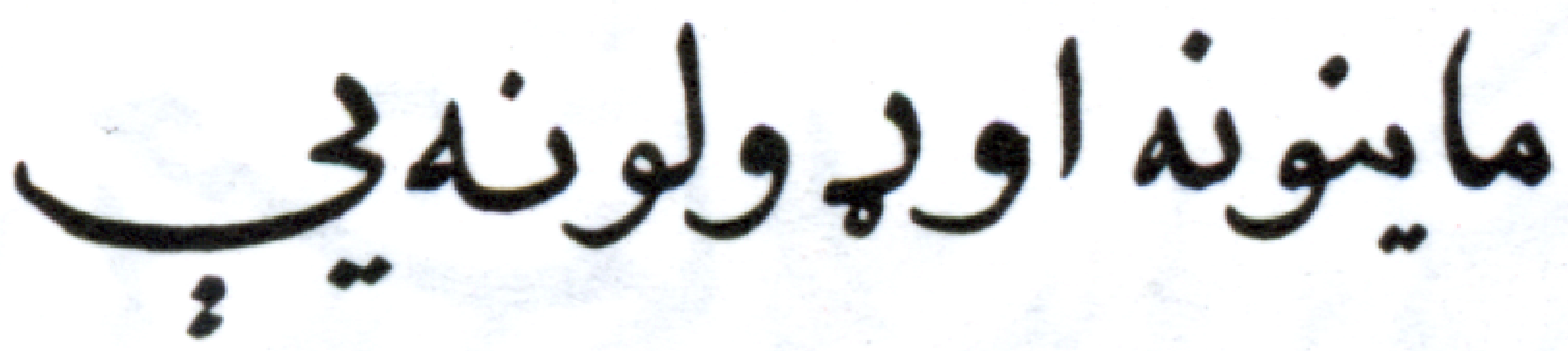

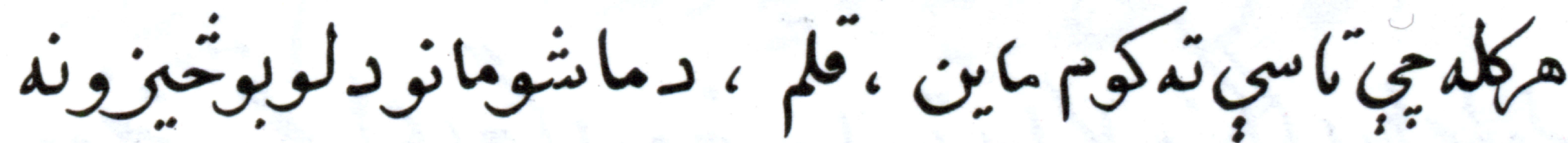

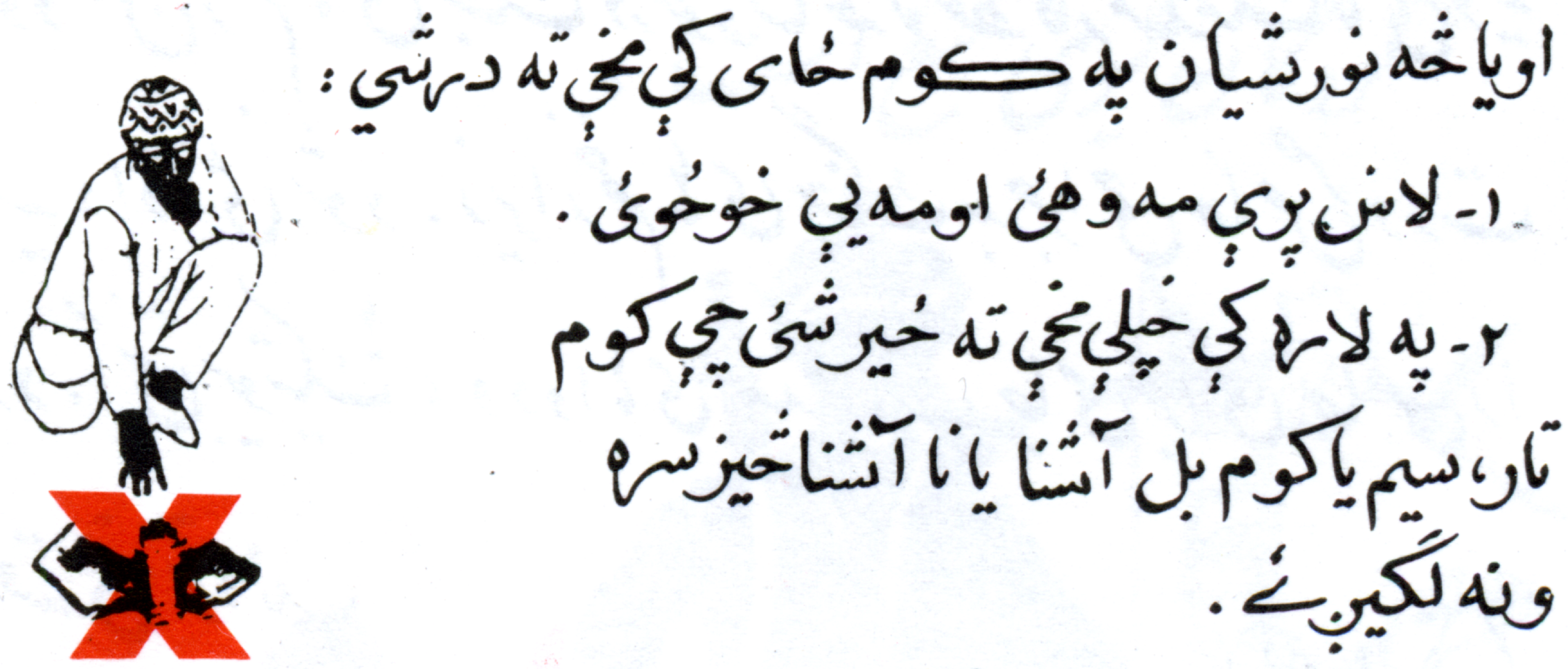

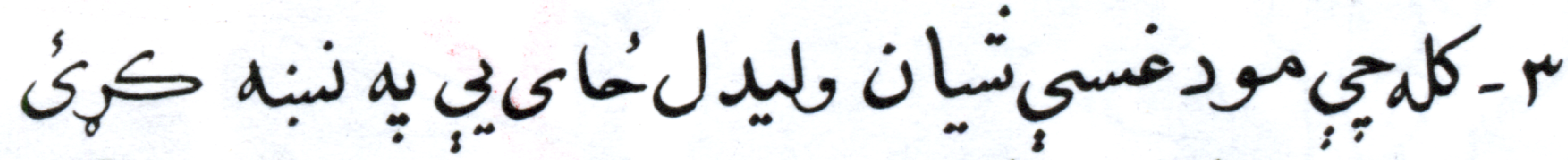

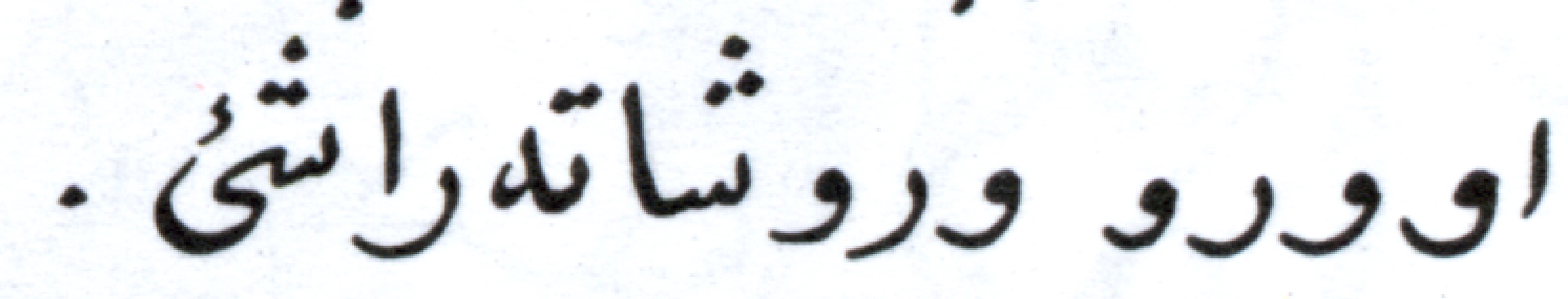

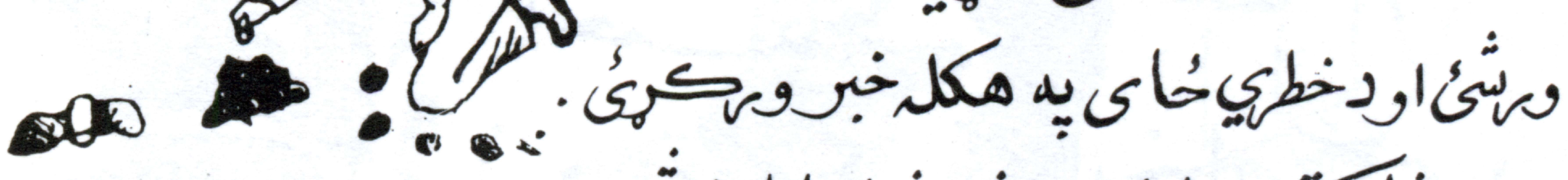

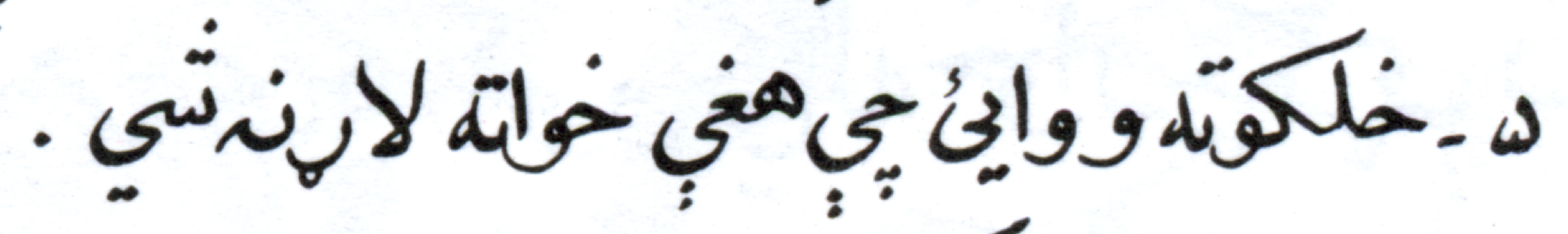

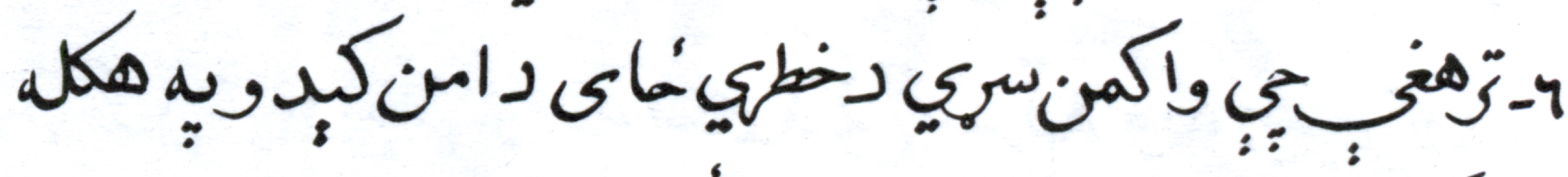

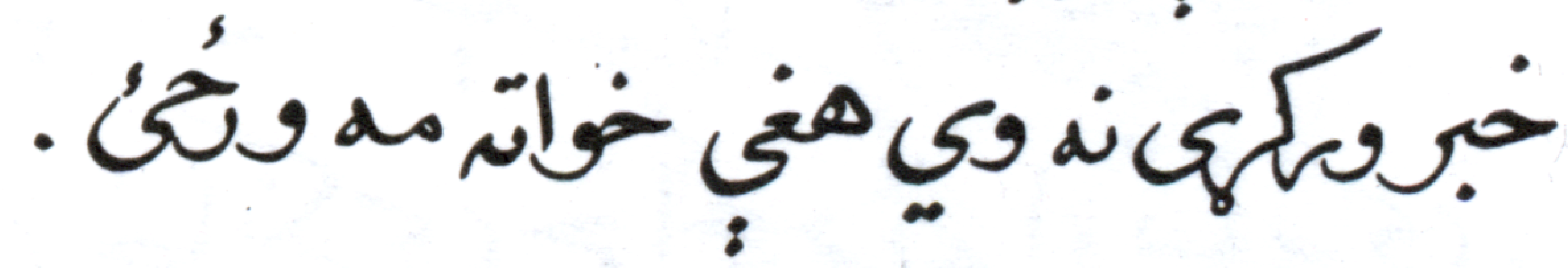

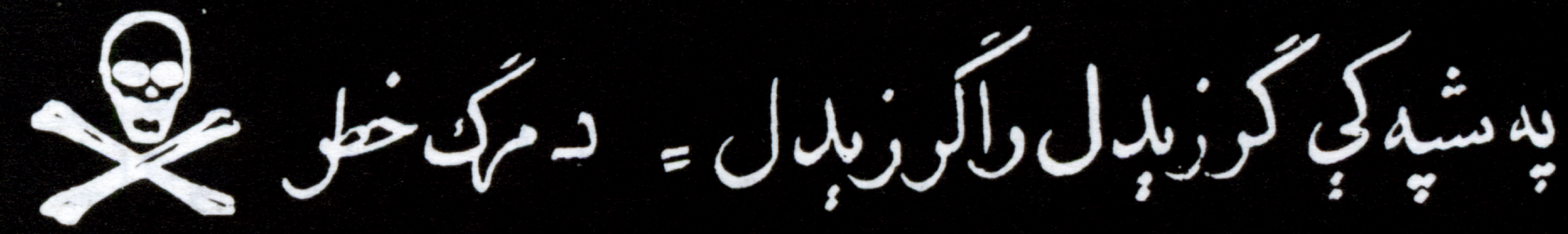




\section{וק"}

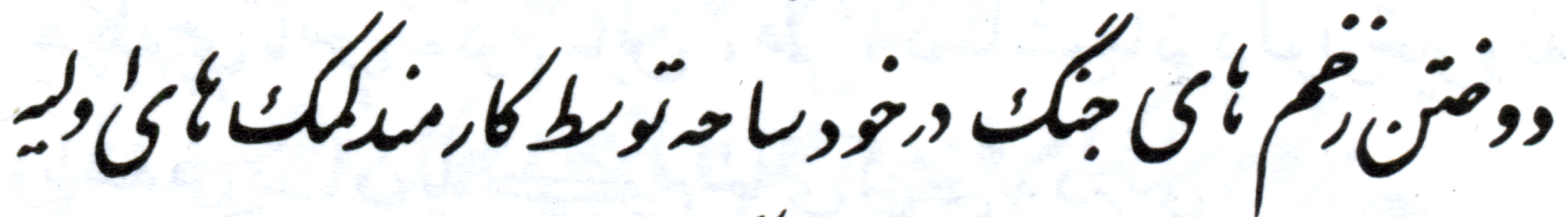

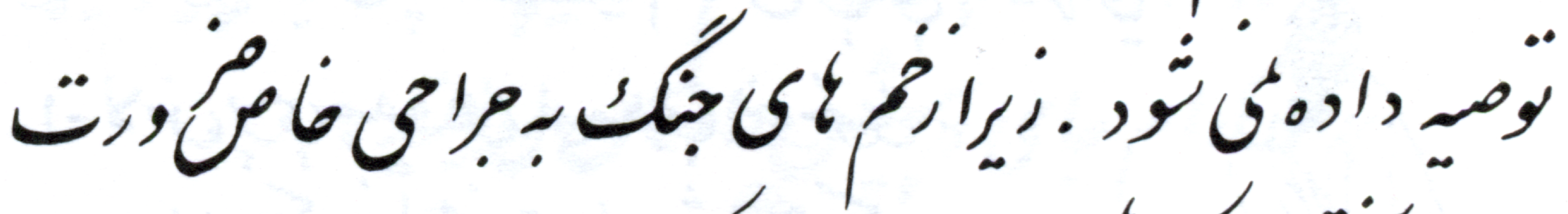

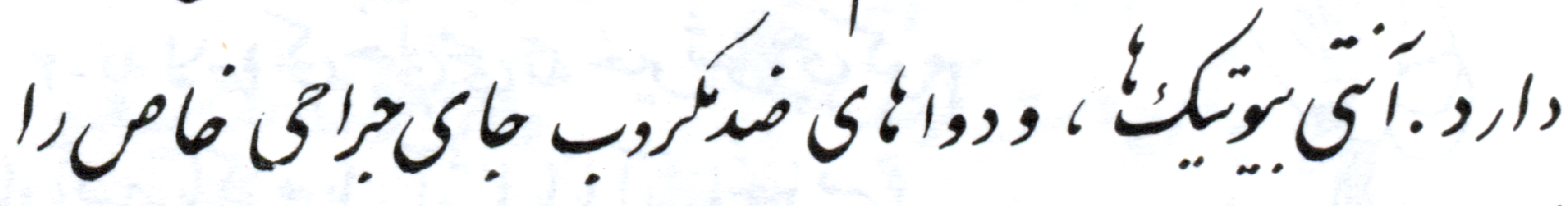
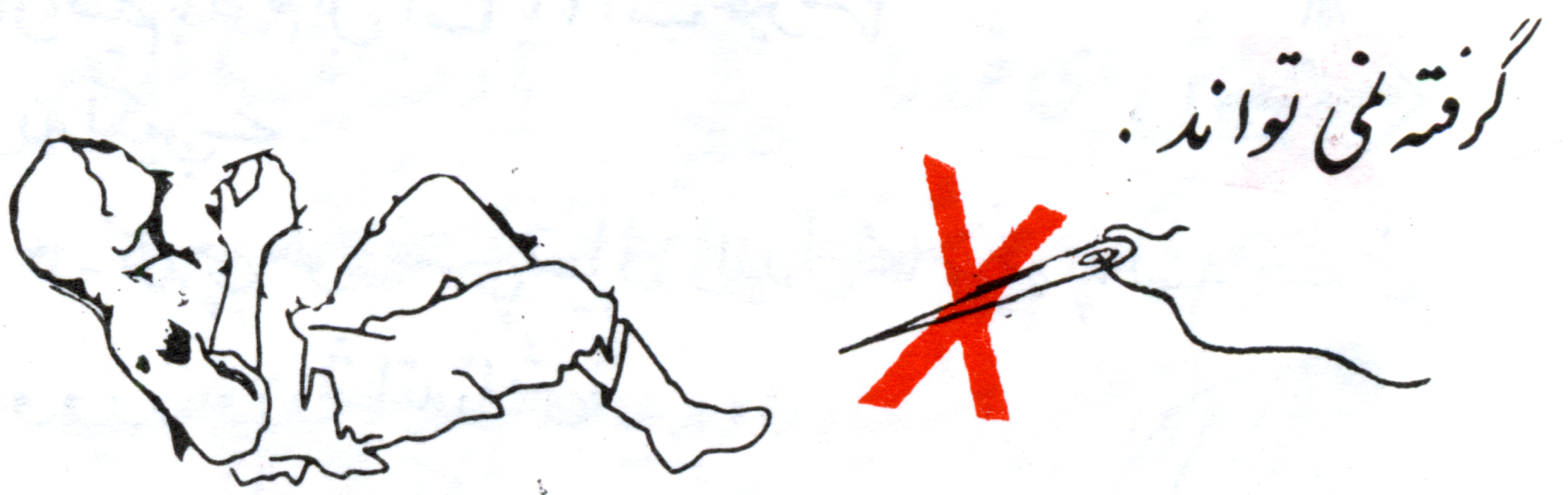

$$
\text { احت" }
$$

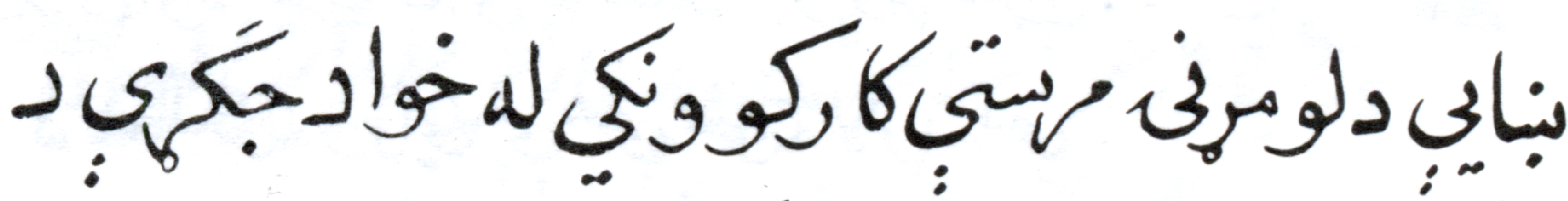

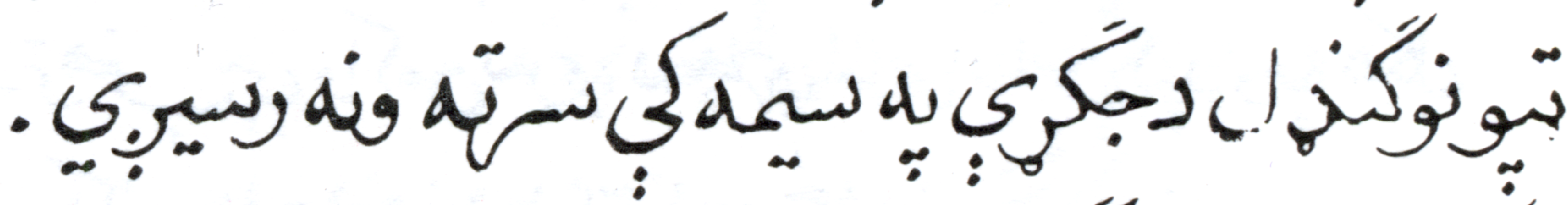

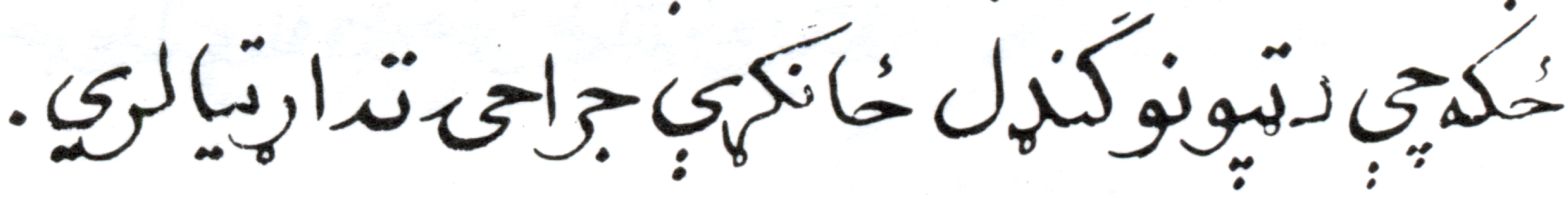

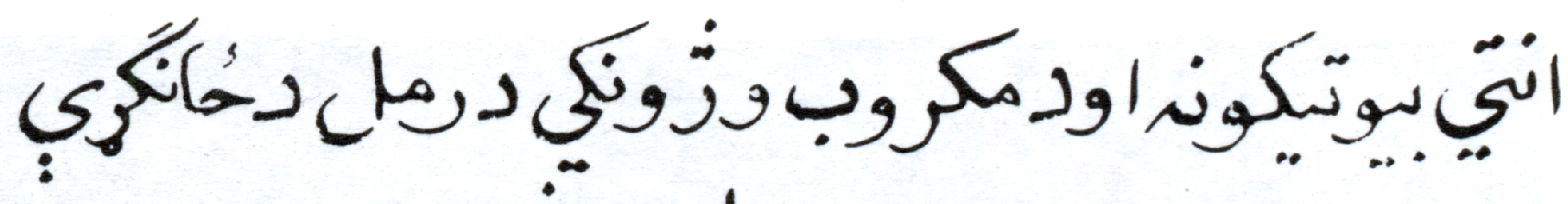

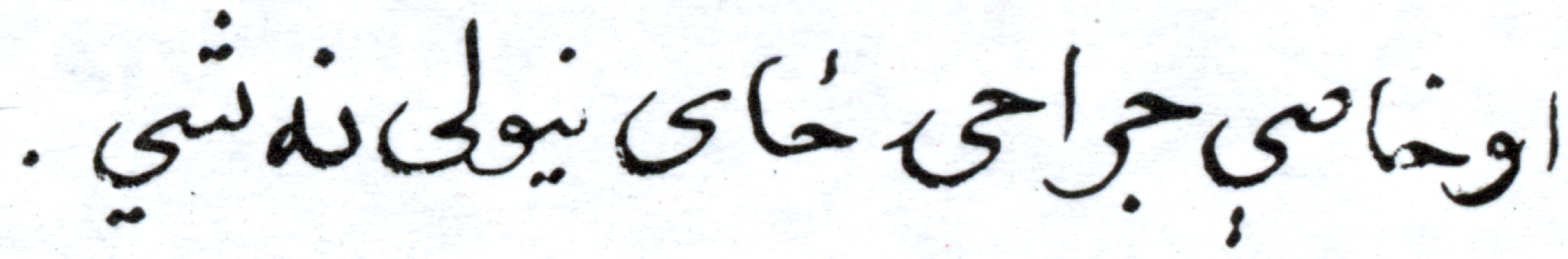




$$
\text { : }
$$

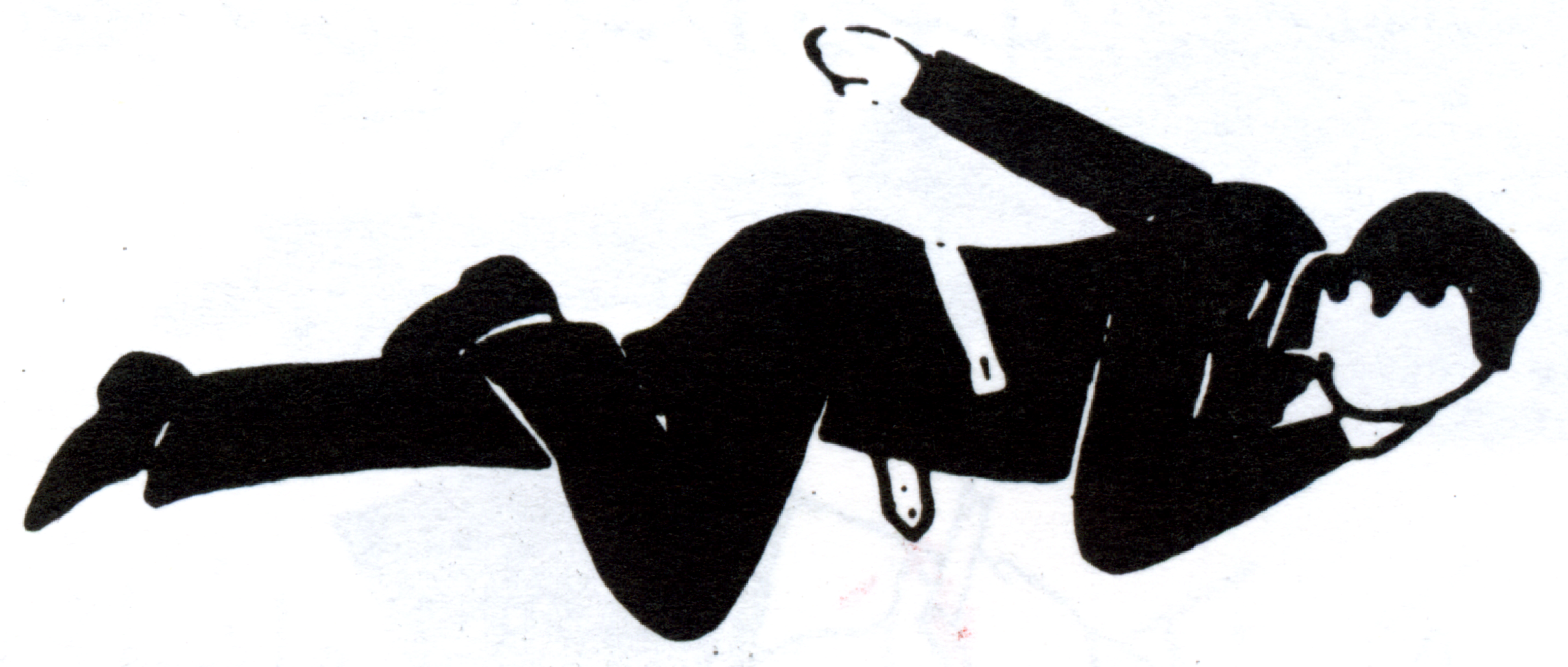




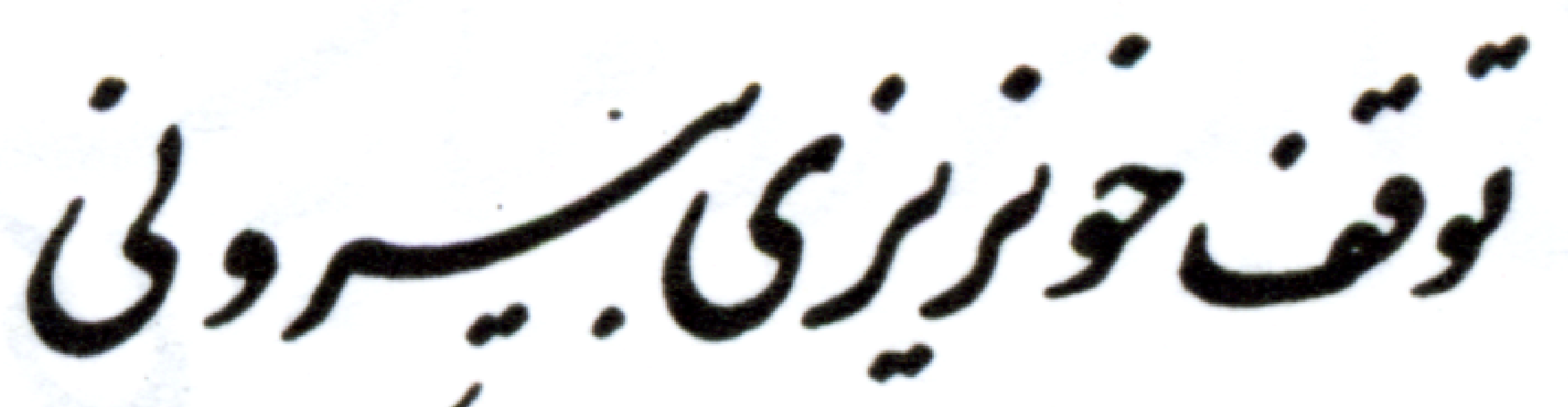

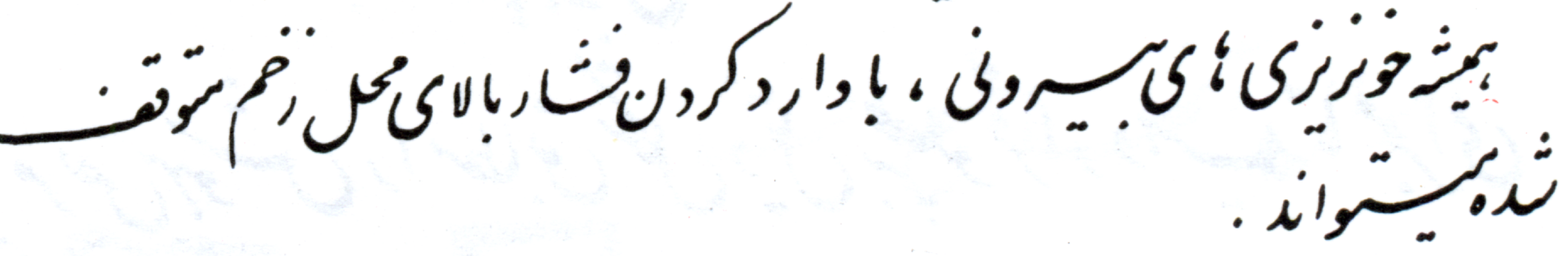

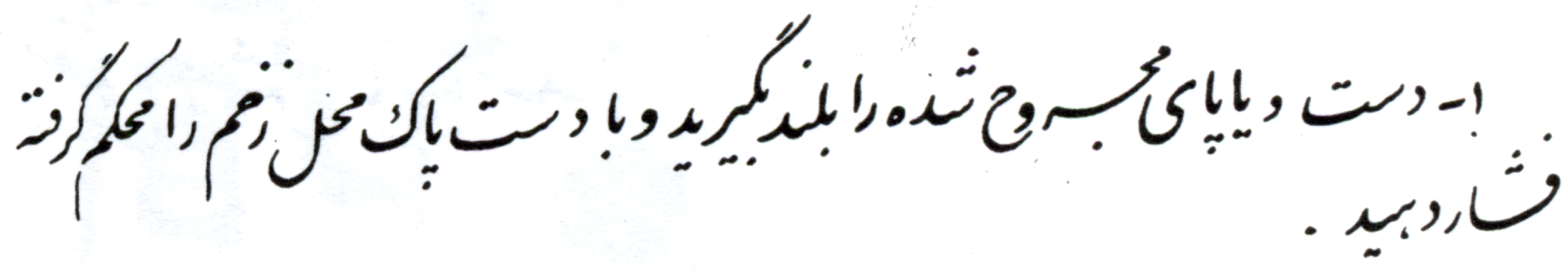

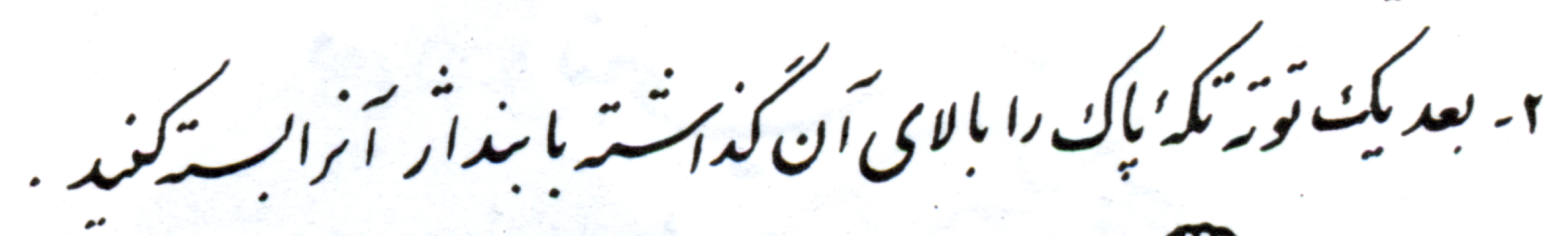

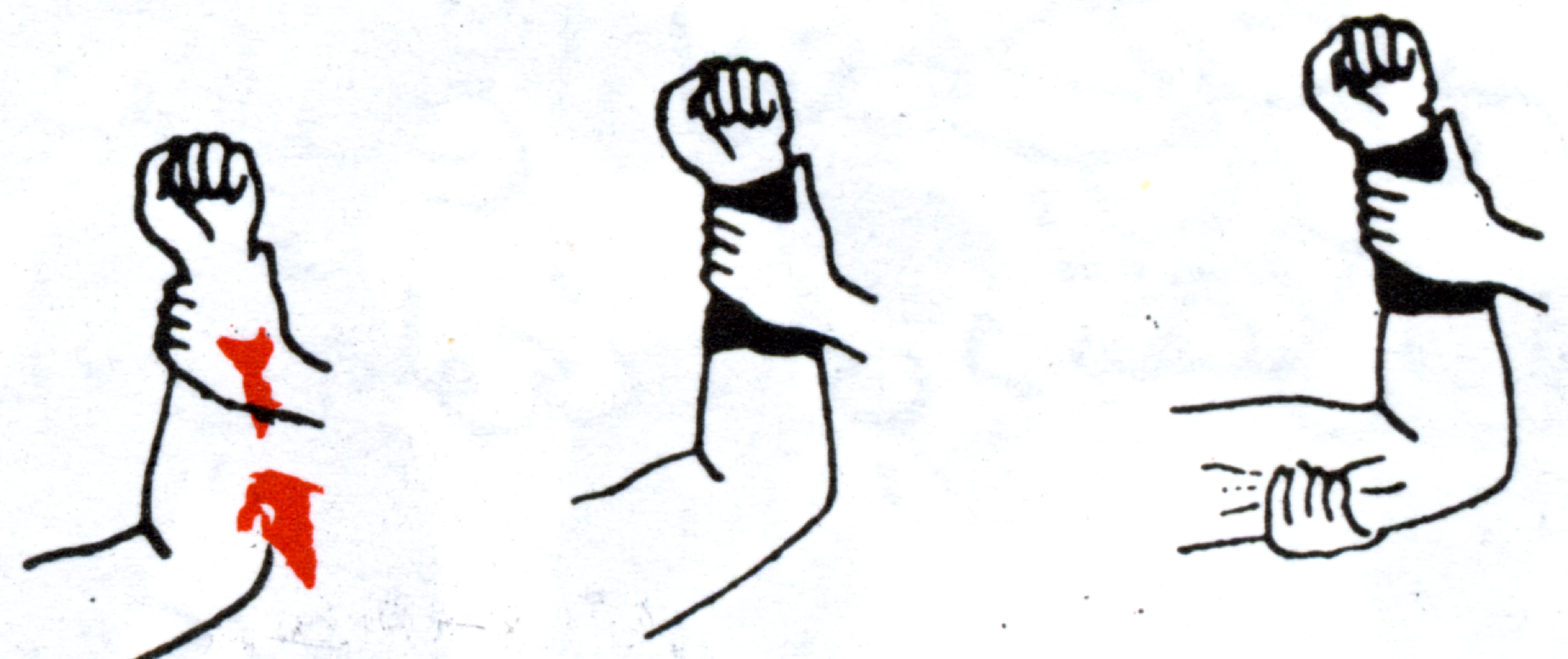

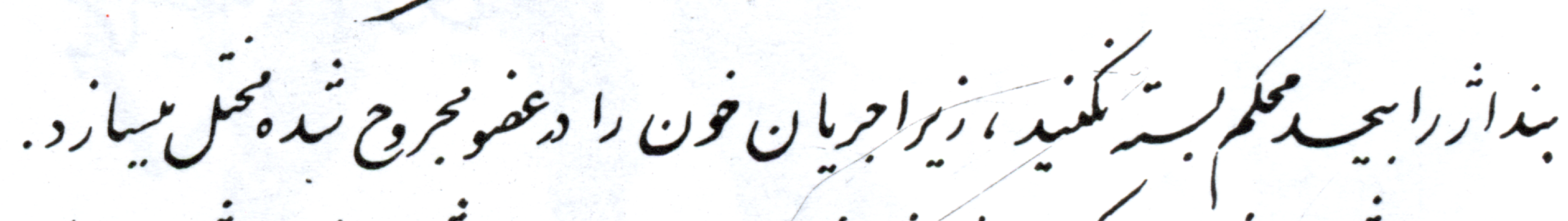

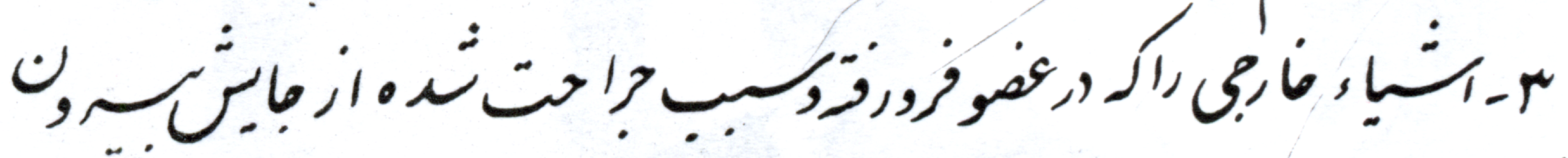

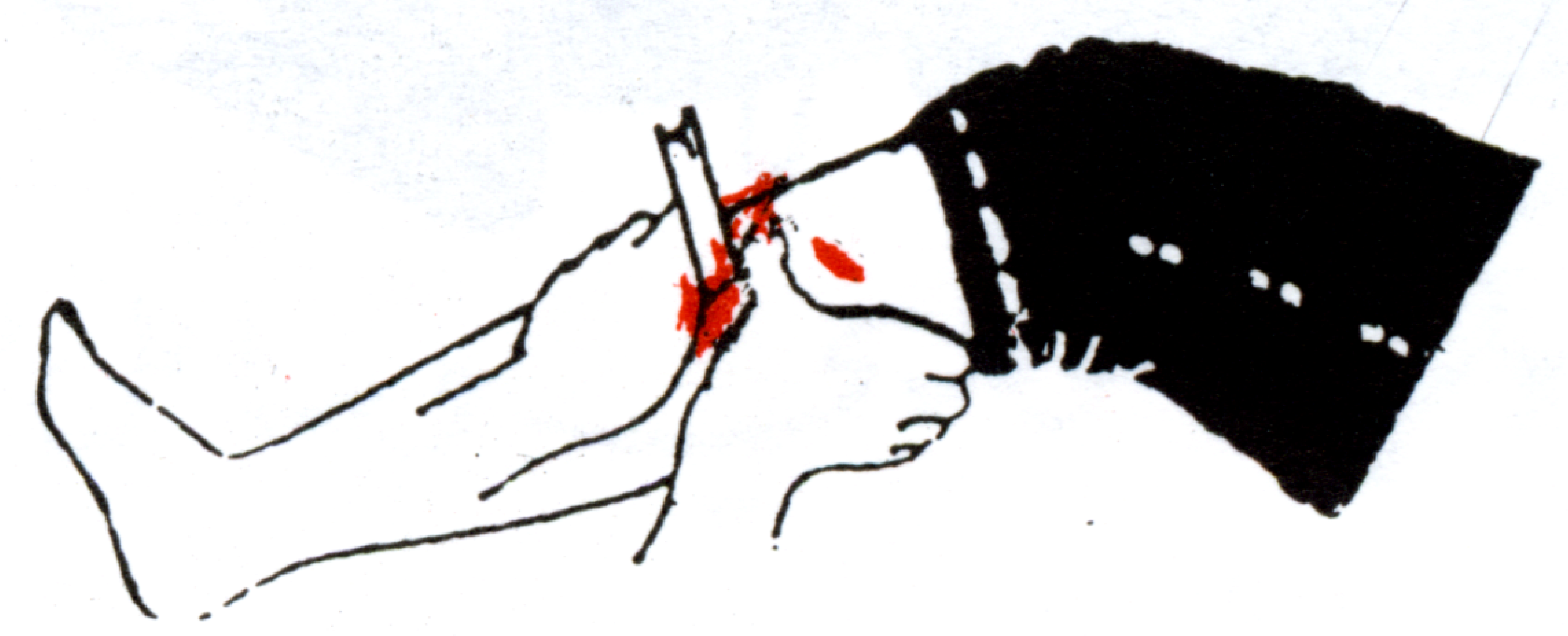




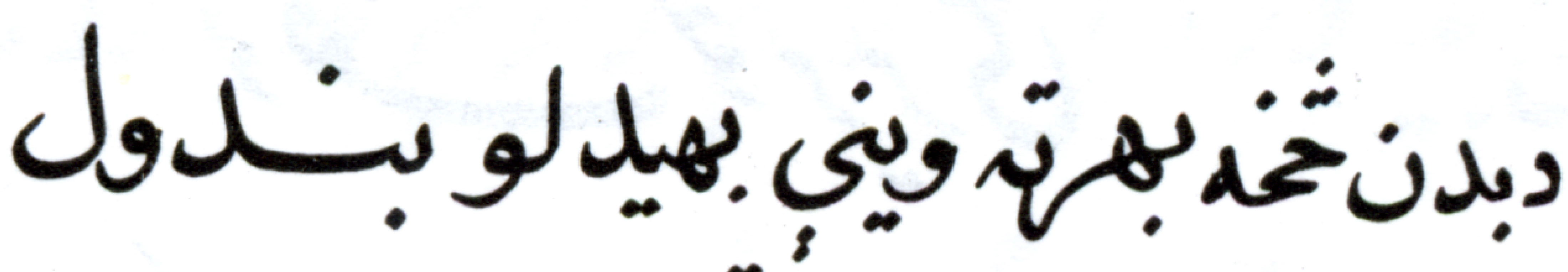

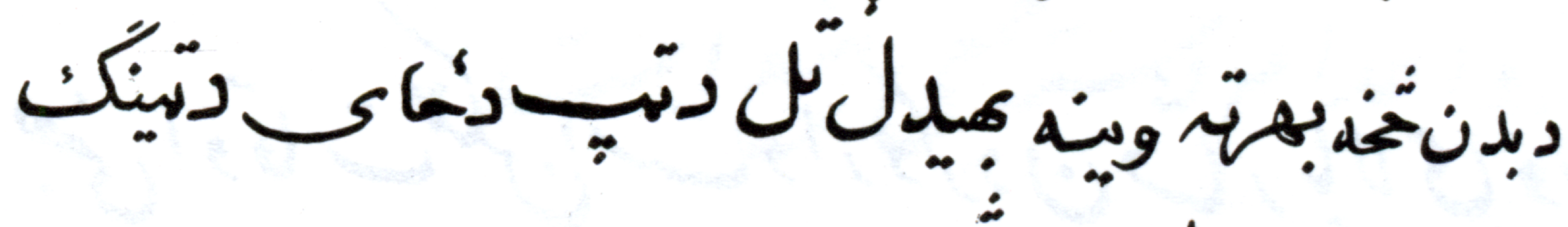

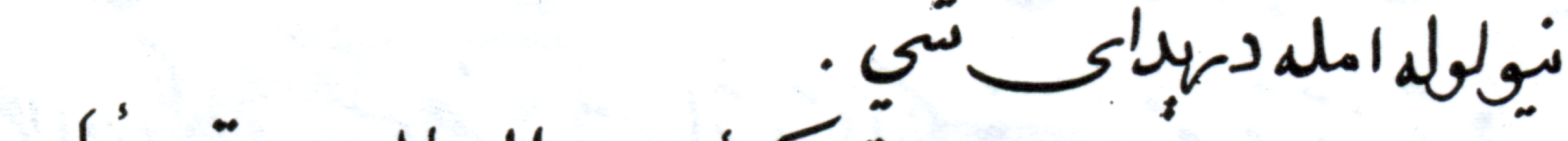

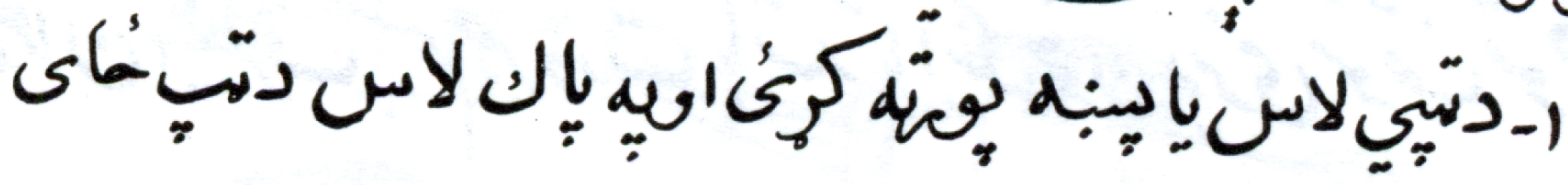

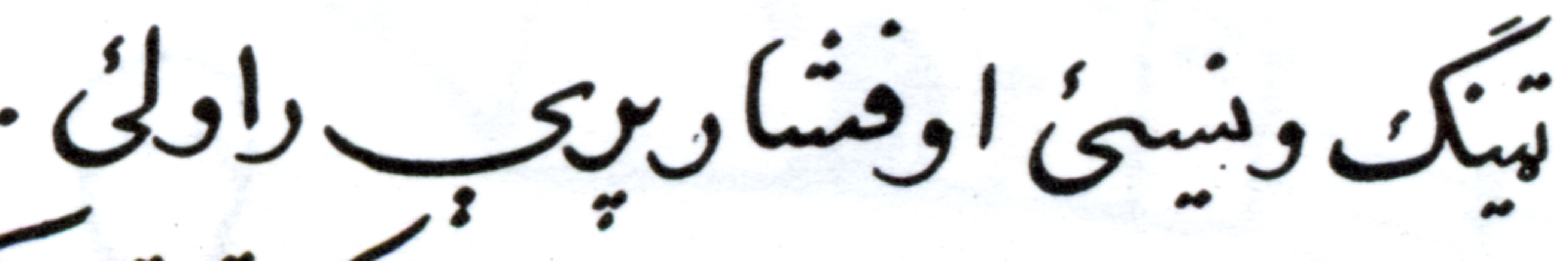

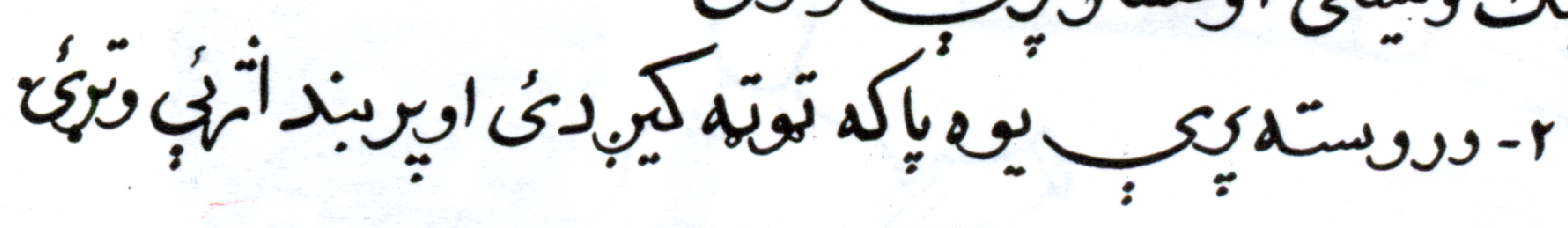
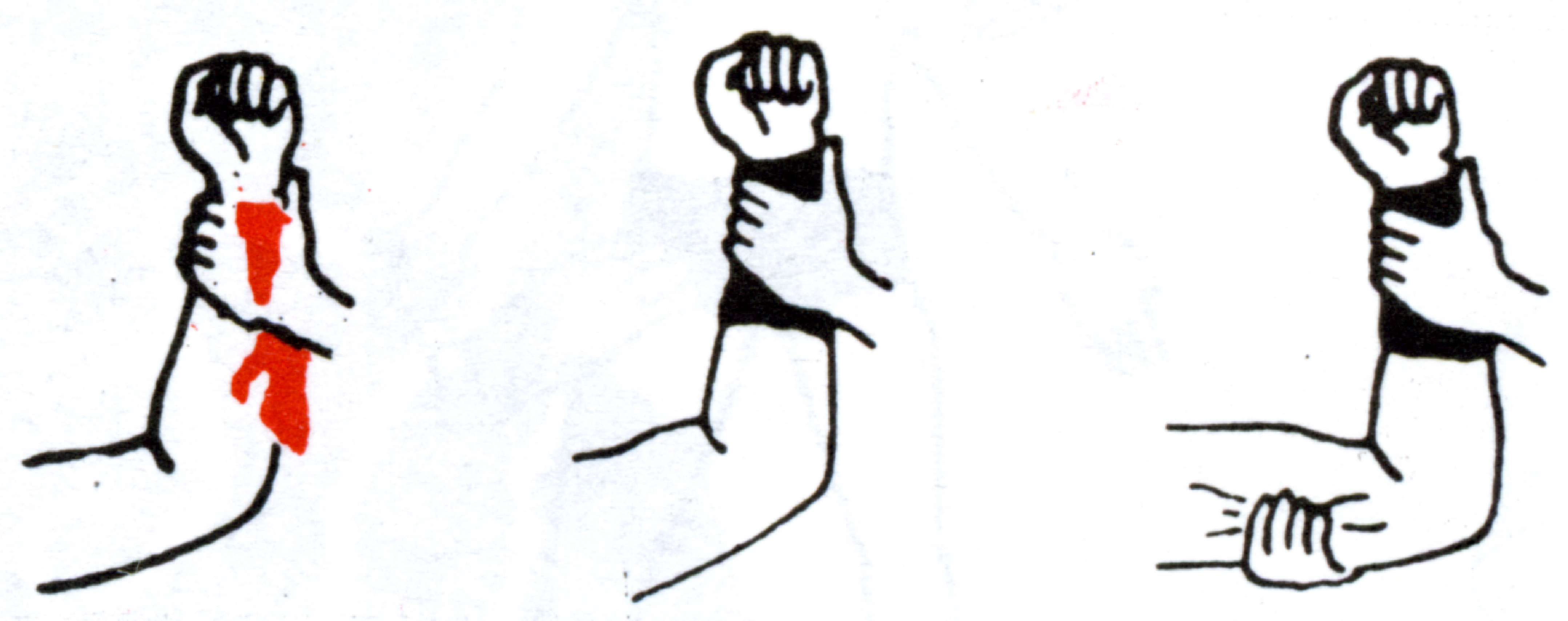

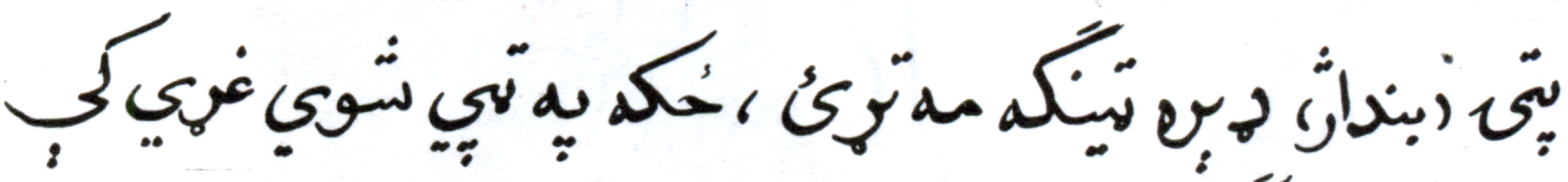

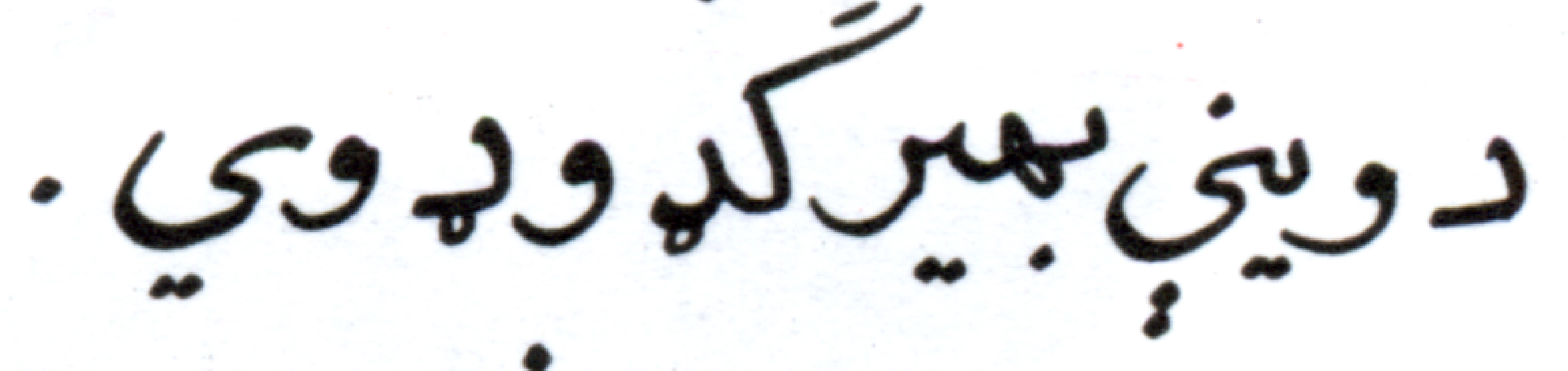

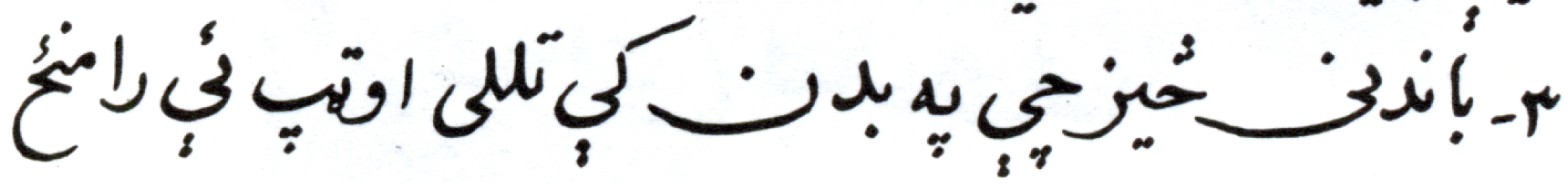

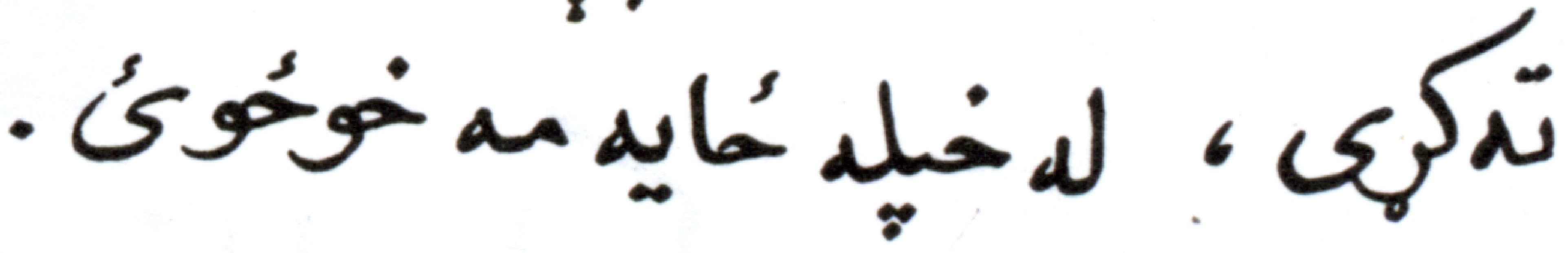

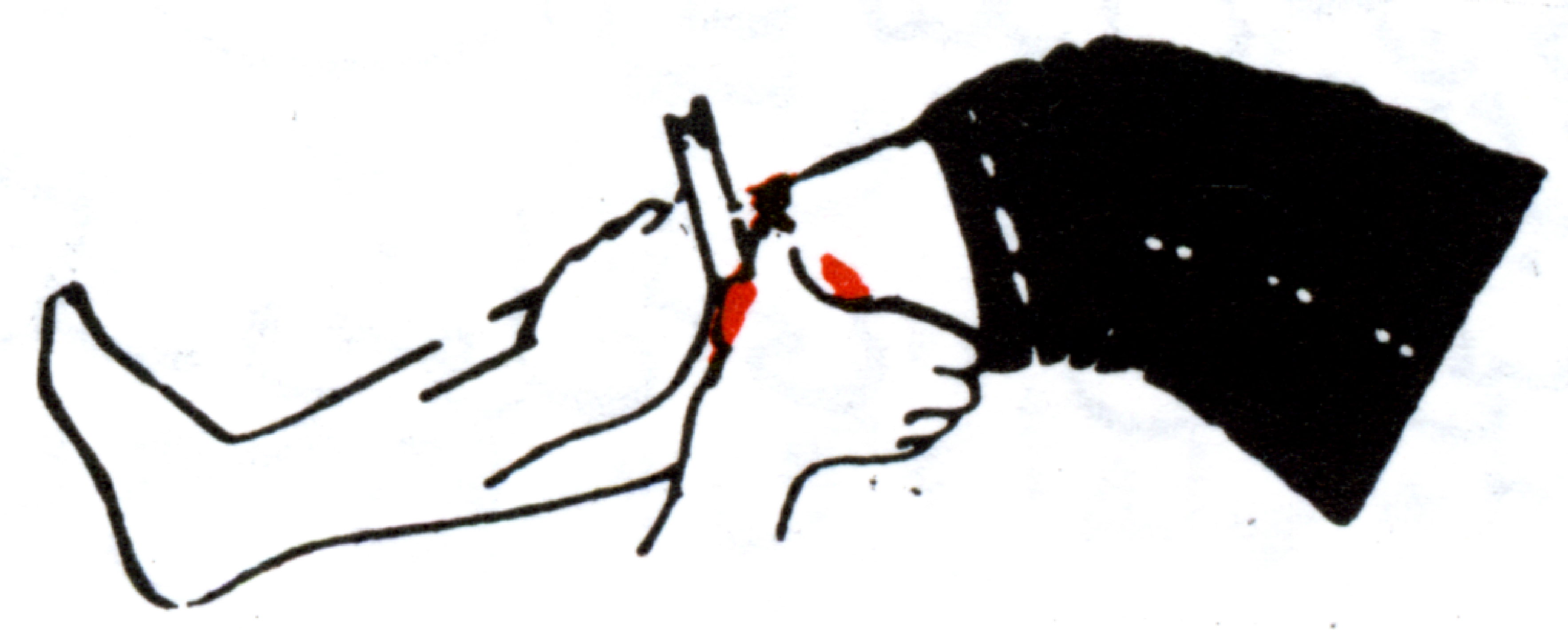




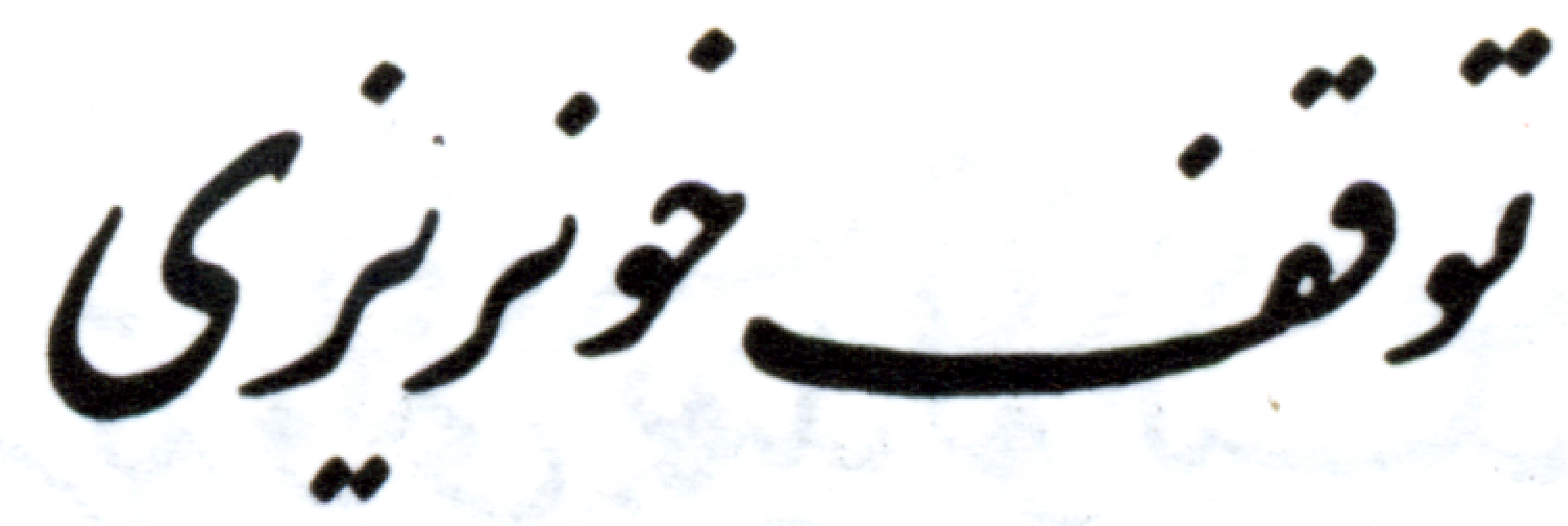

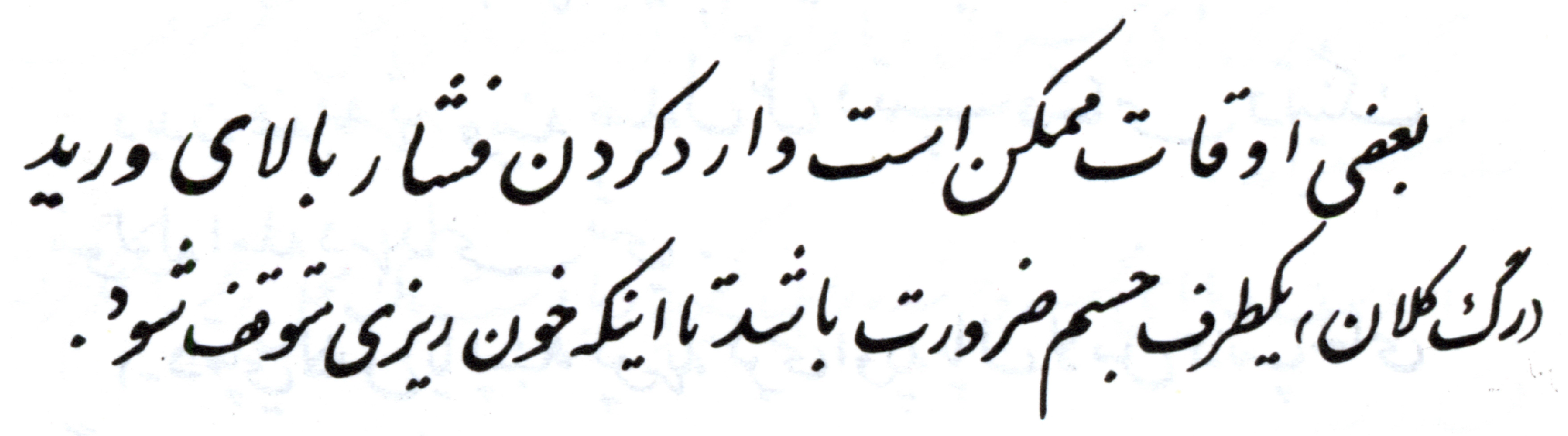

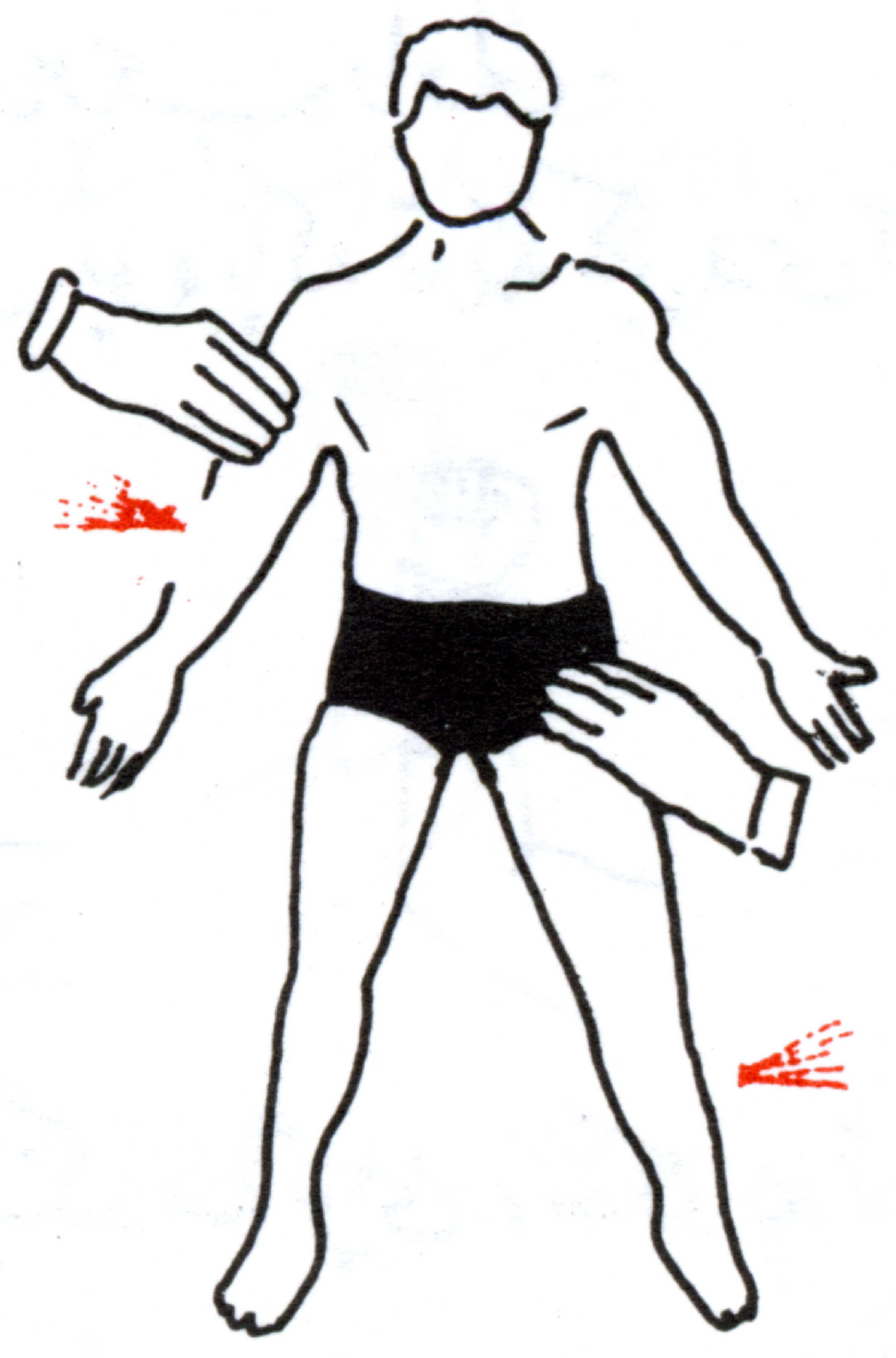

دوني بندول

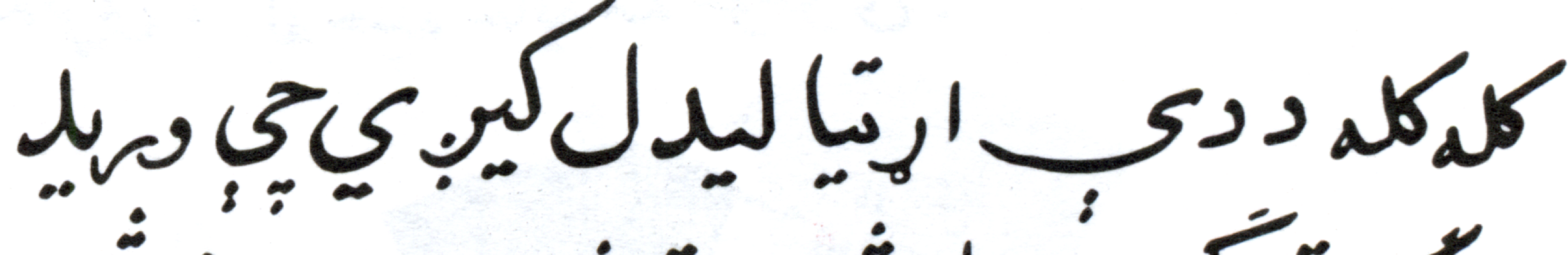

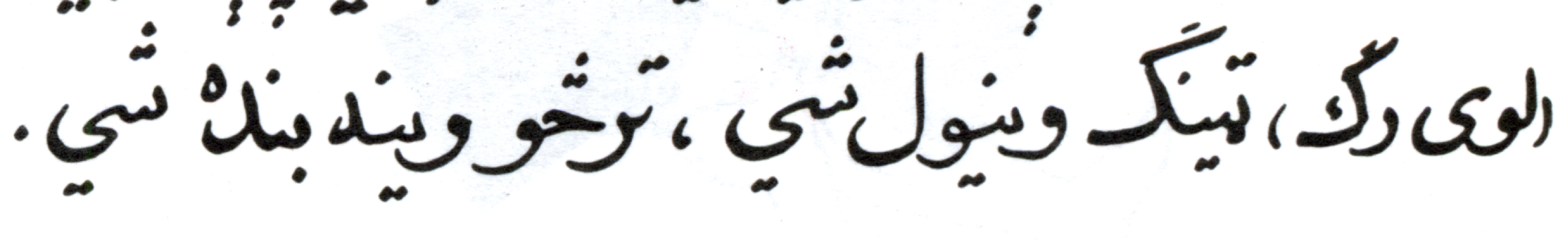




\section{.}

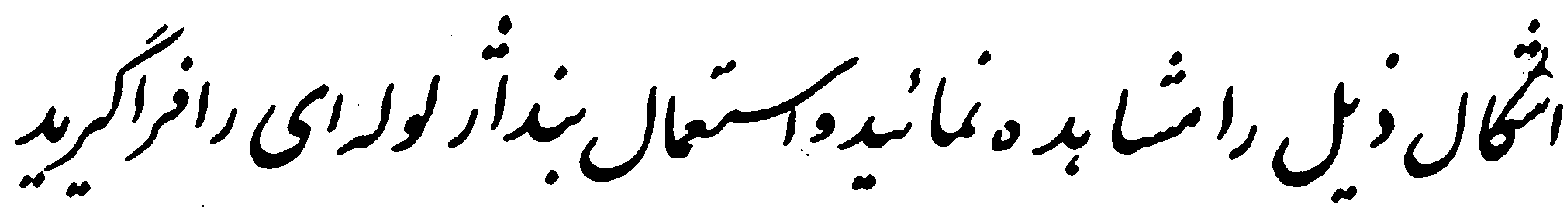

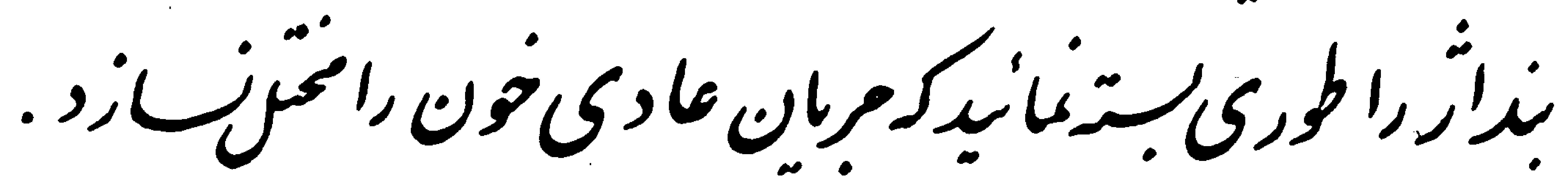
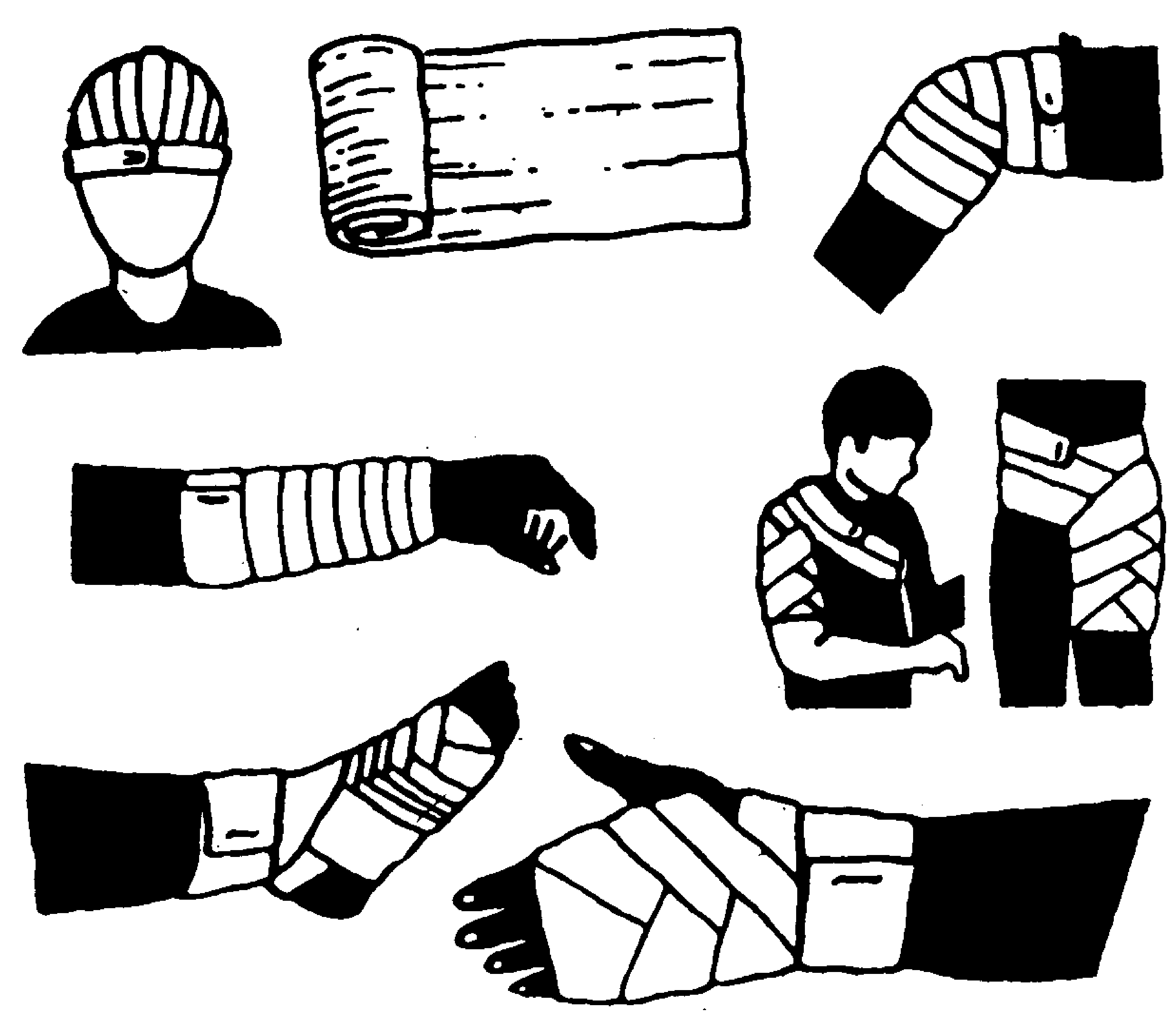

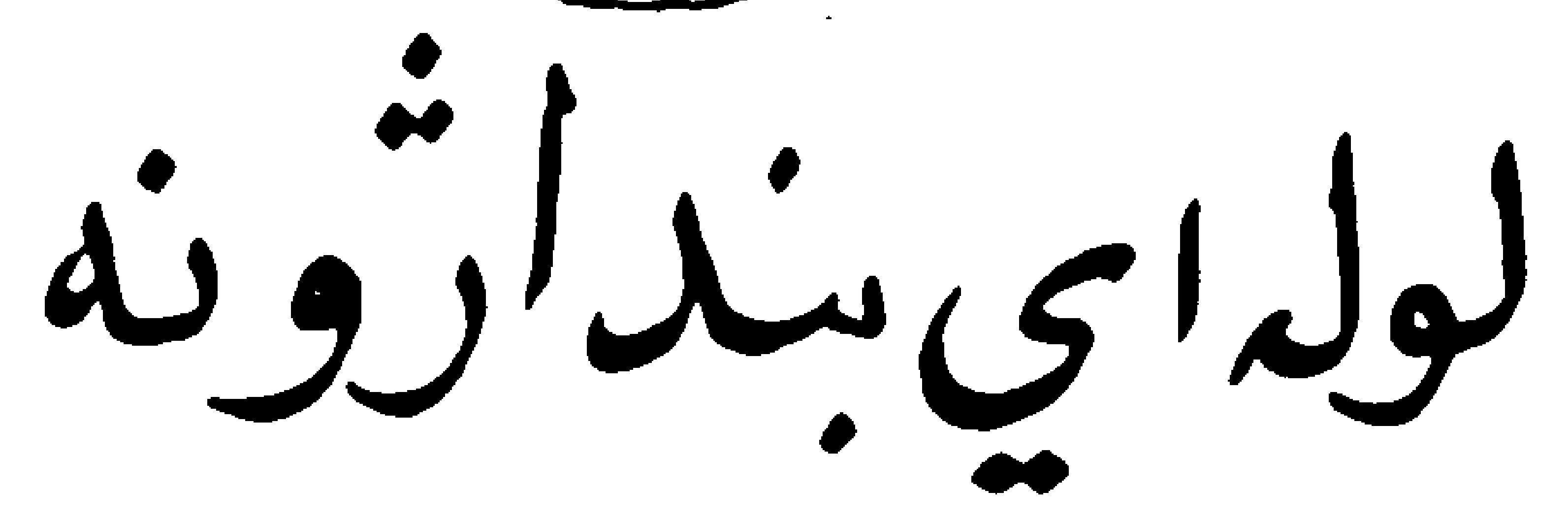

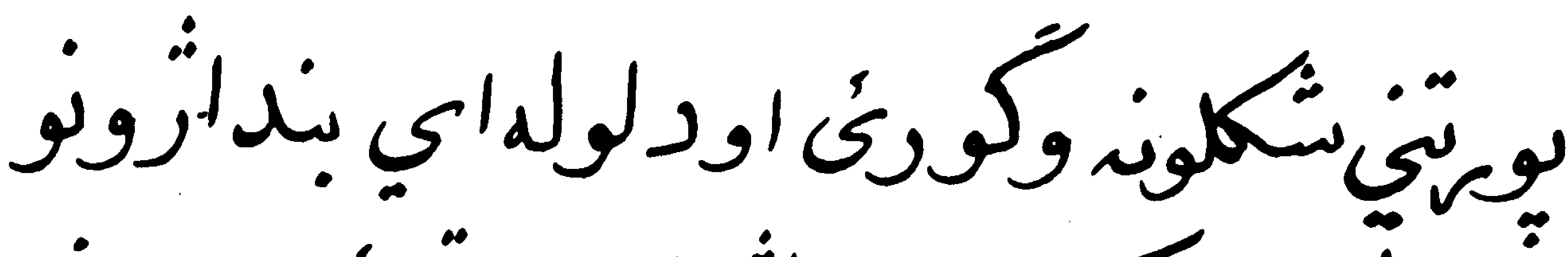

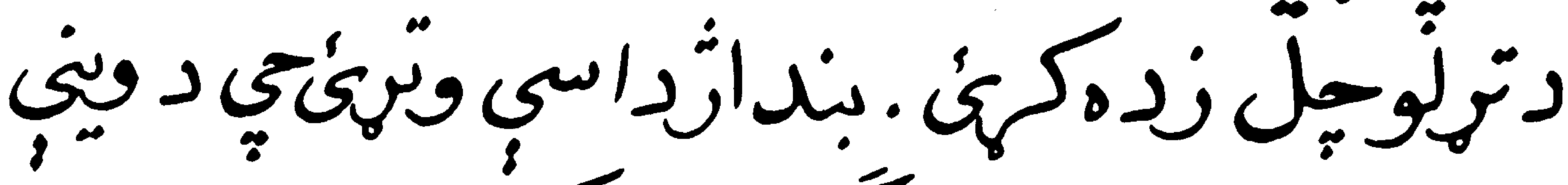

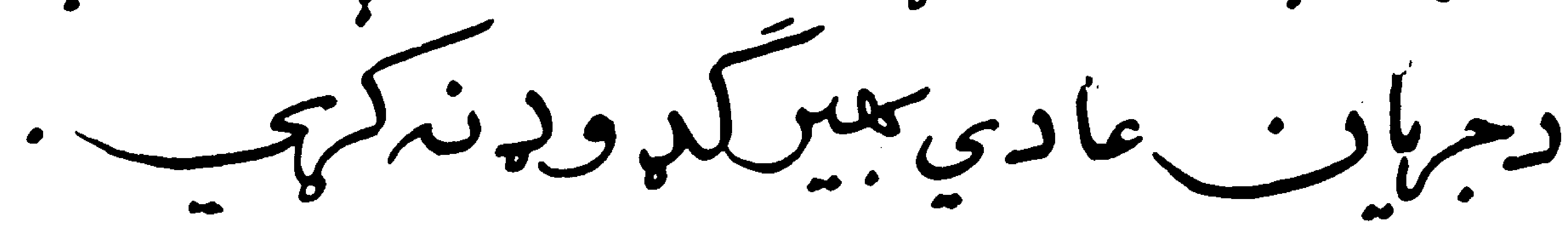



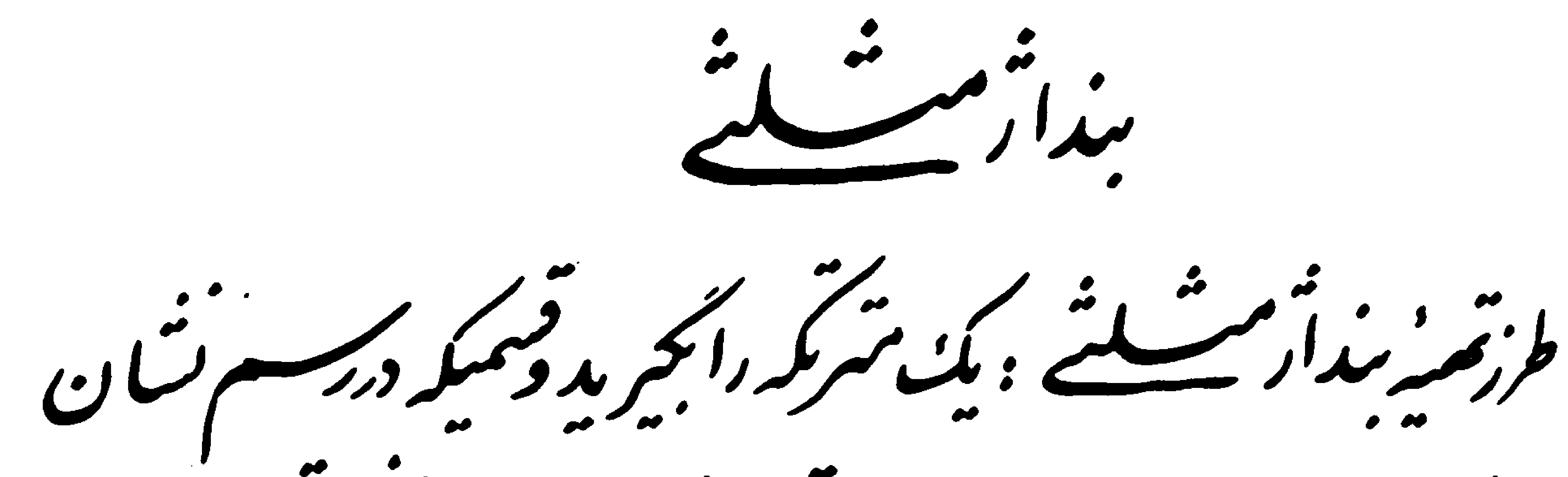

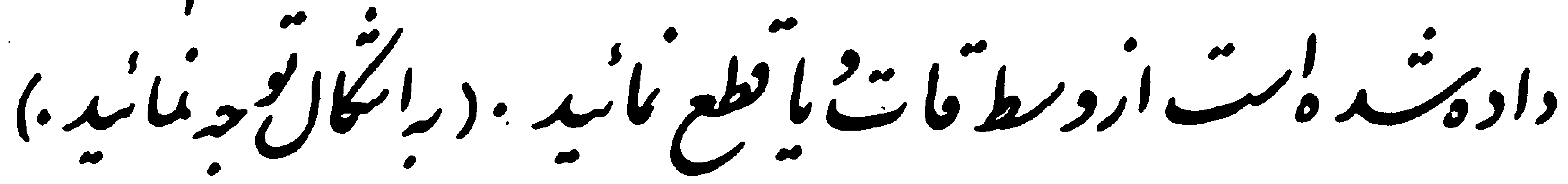
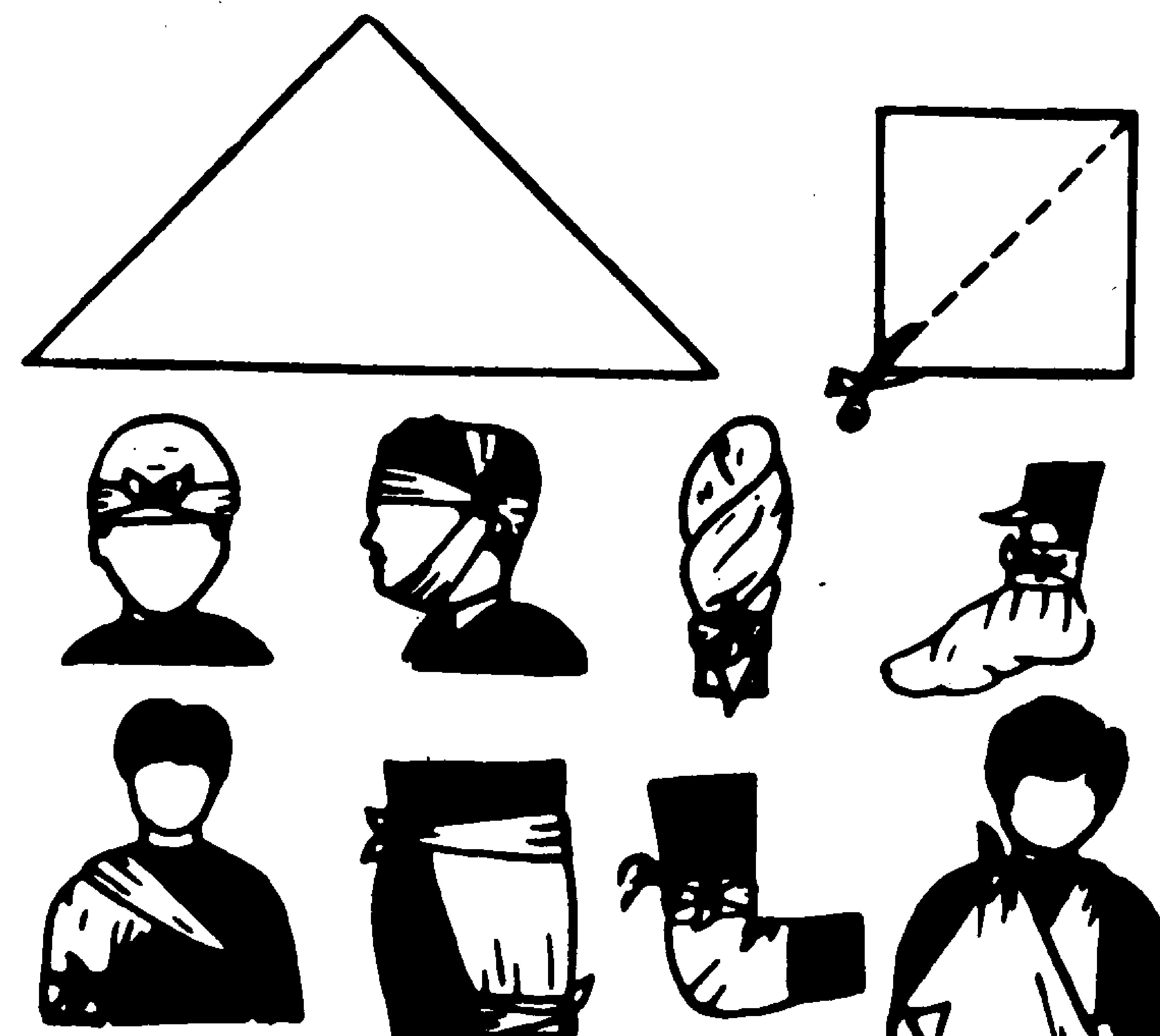

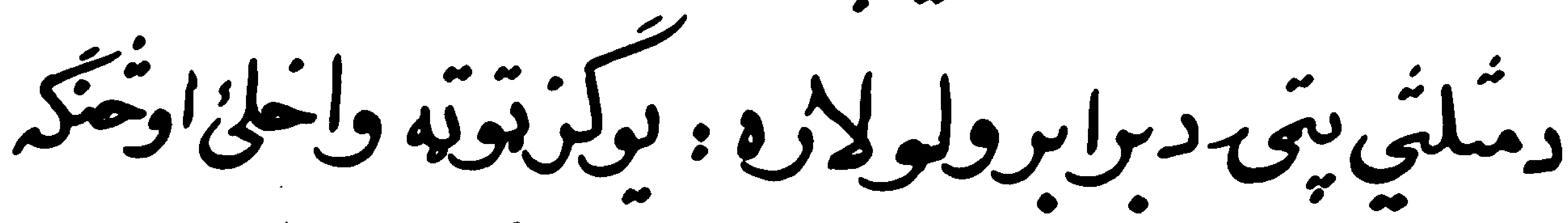
$\underbrace{\infty}_{\infty}$

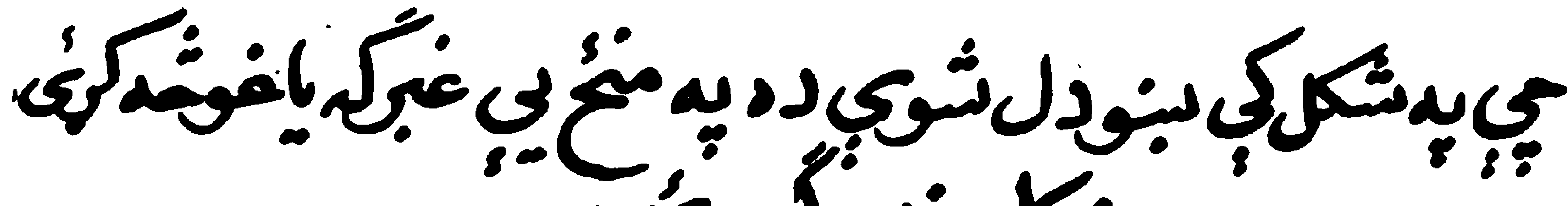
( منكلمنه وكقئ) 


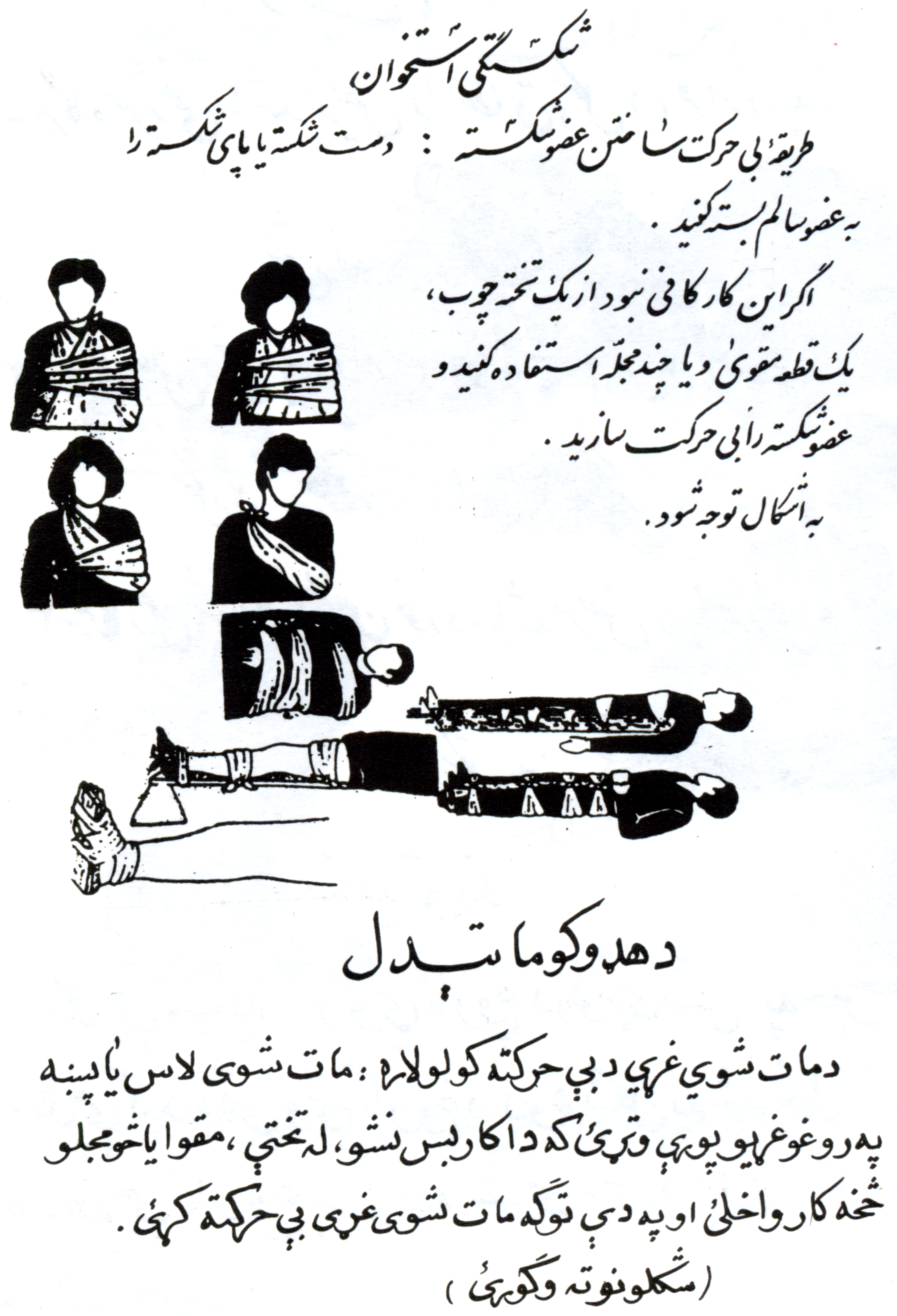


وفمتص

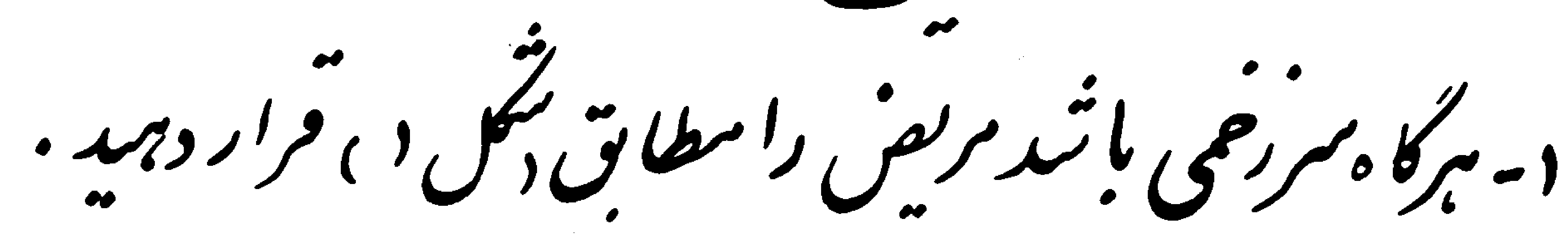

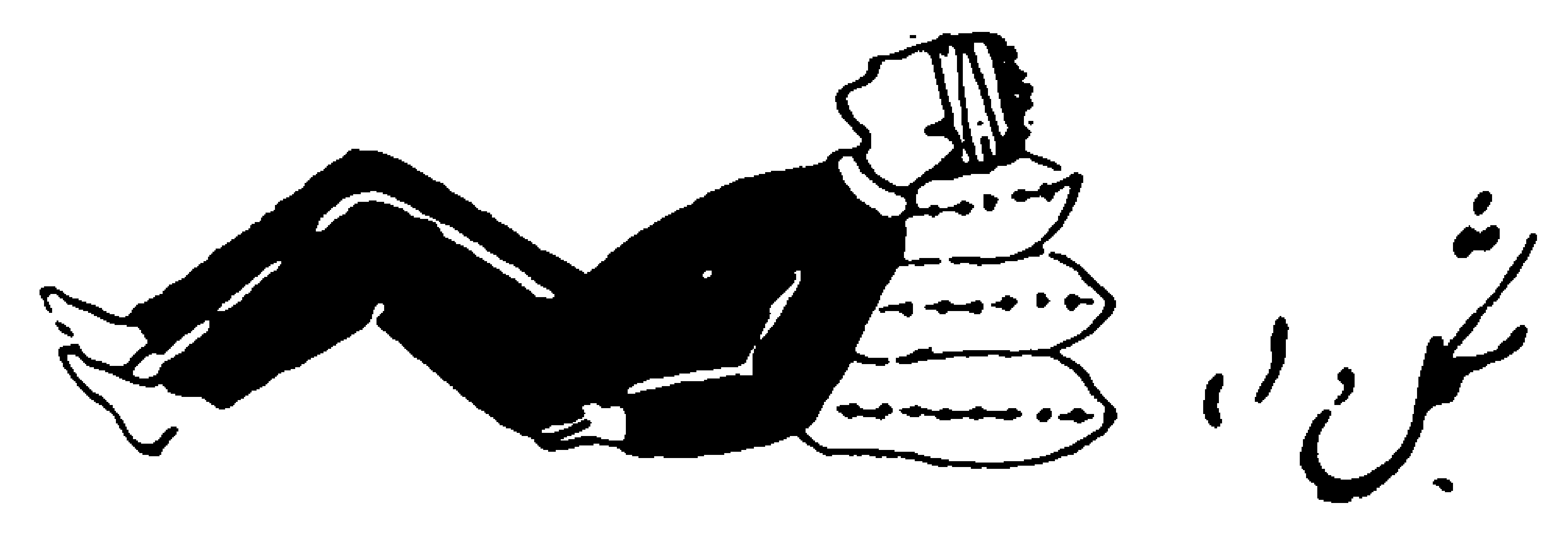

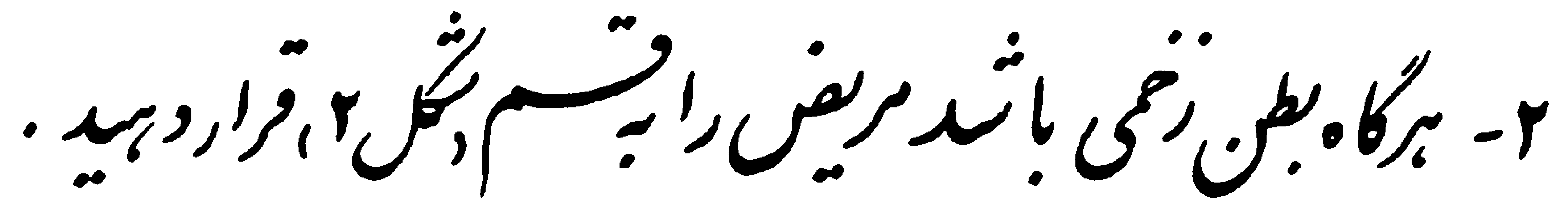

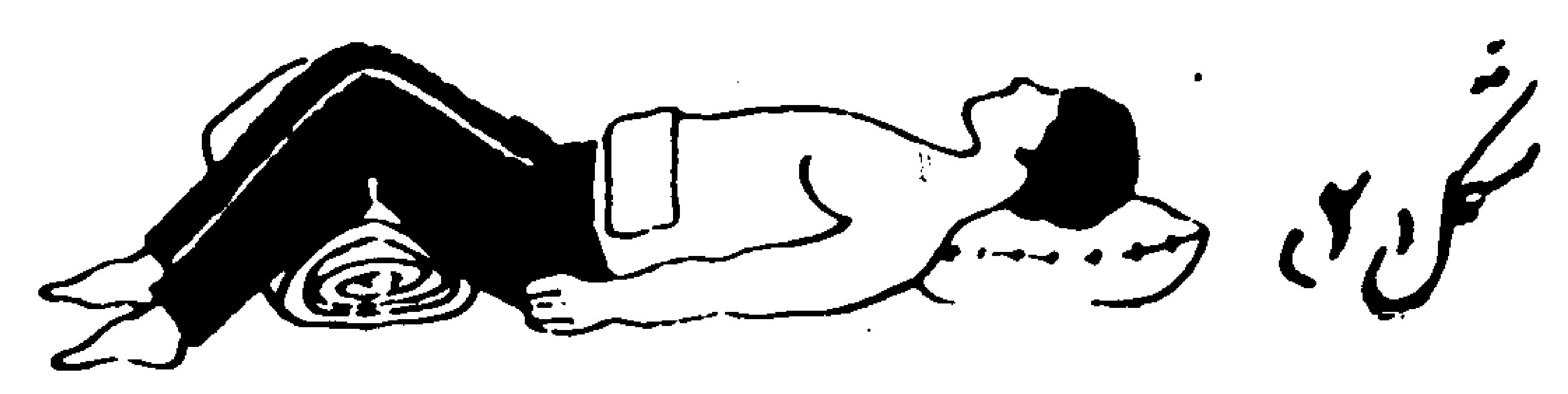

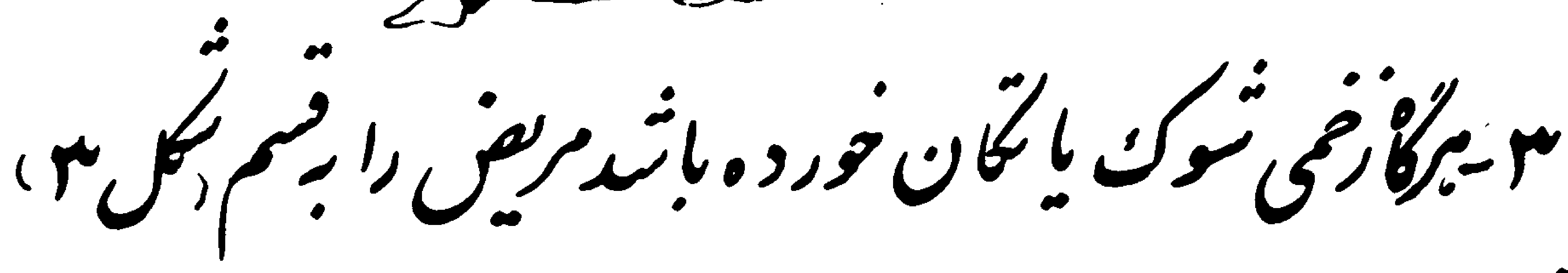

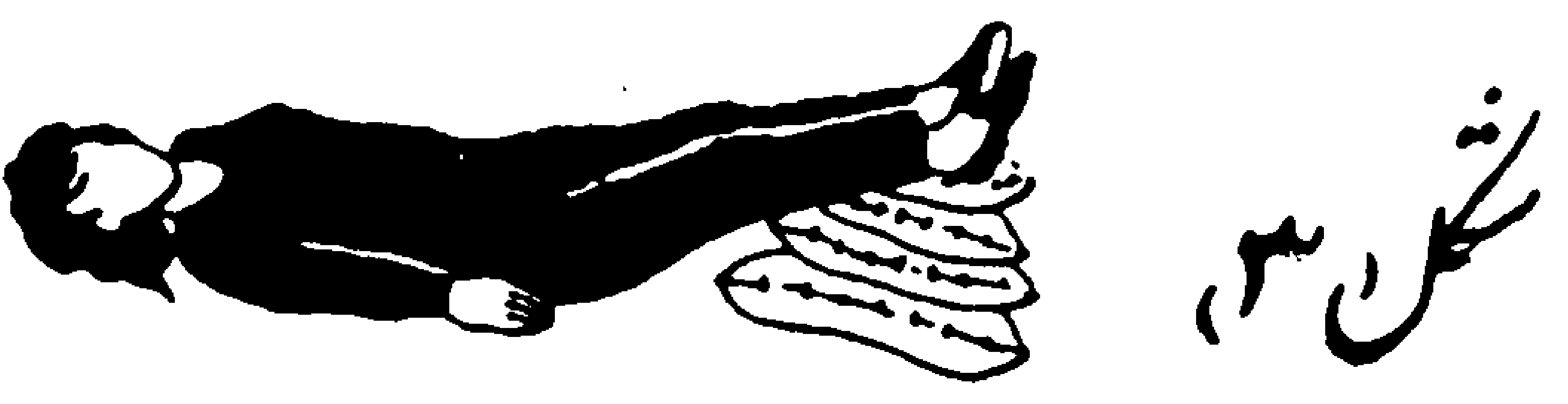

קוر •

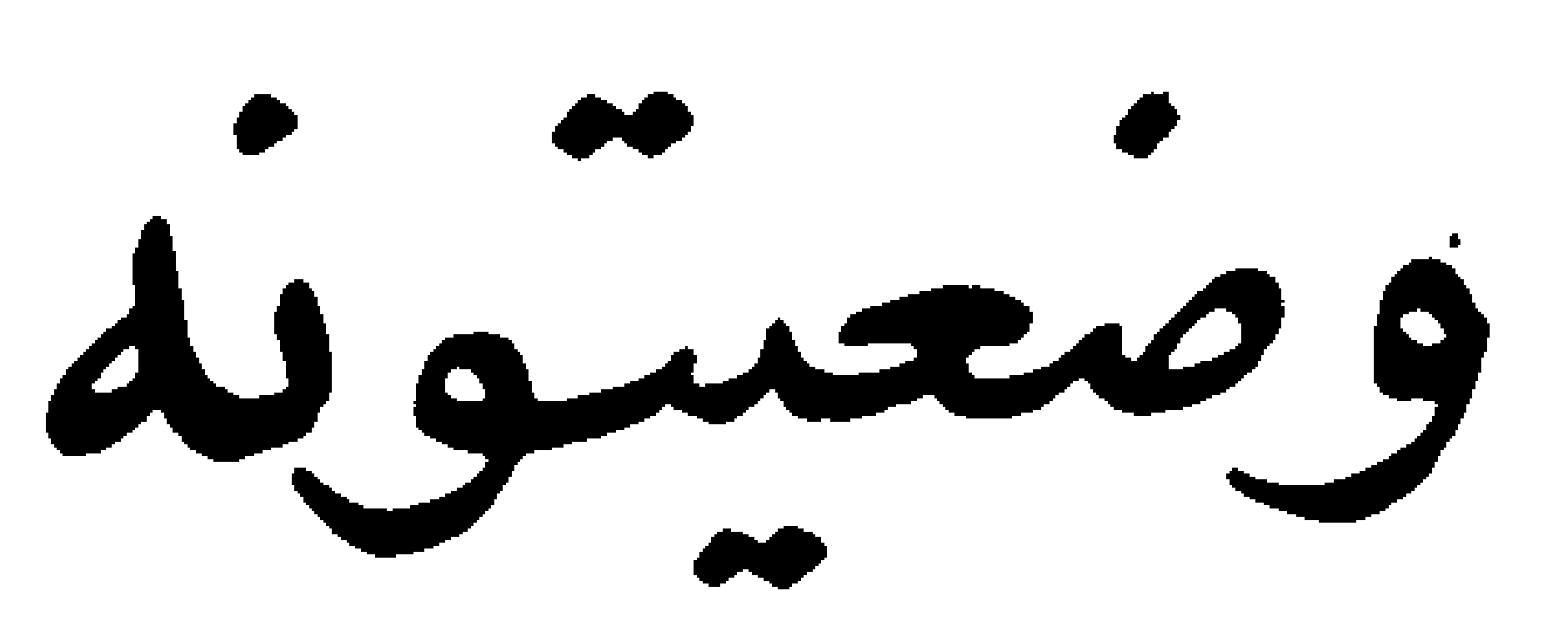

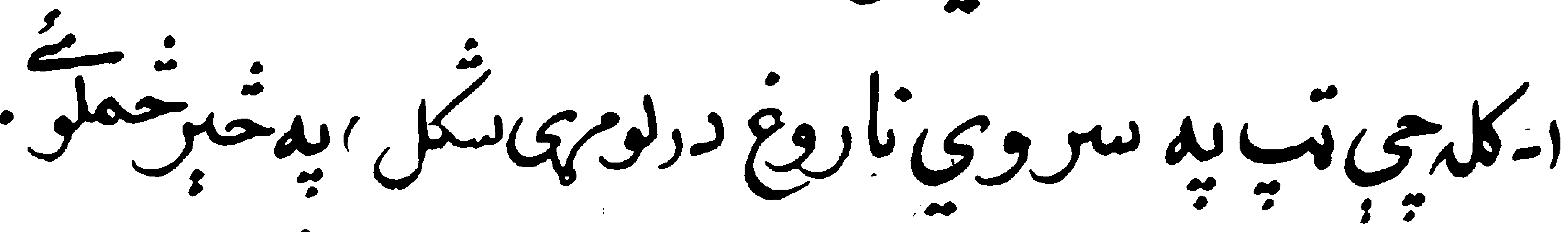

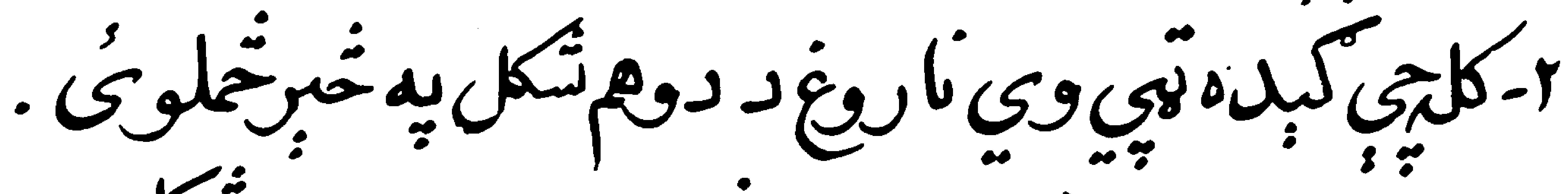

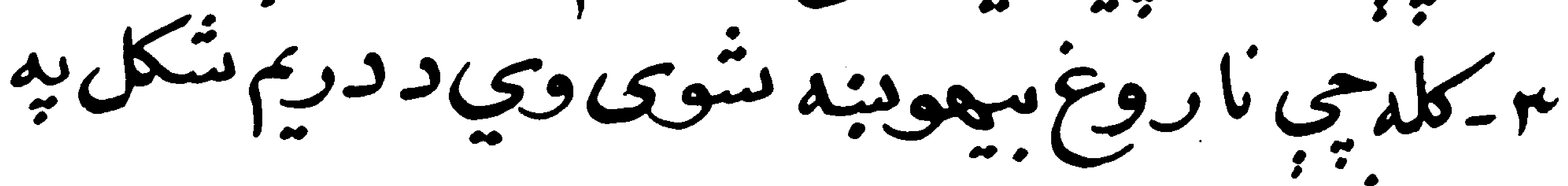

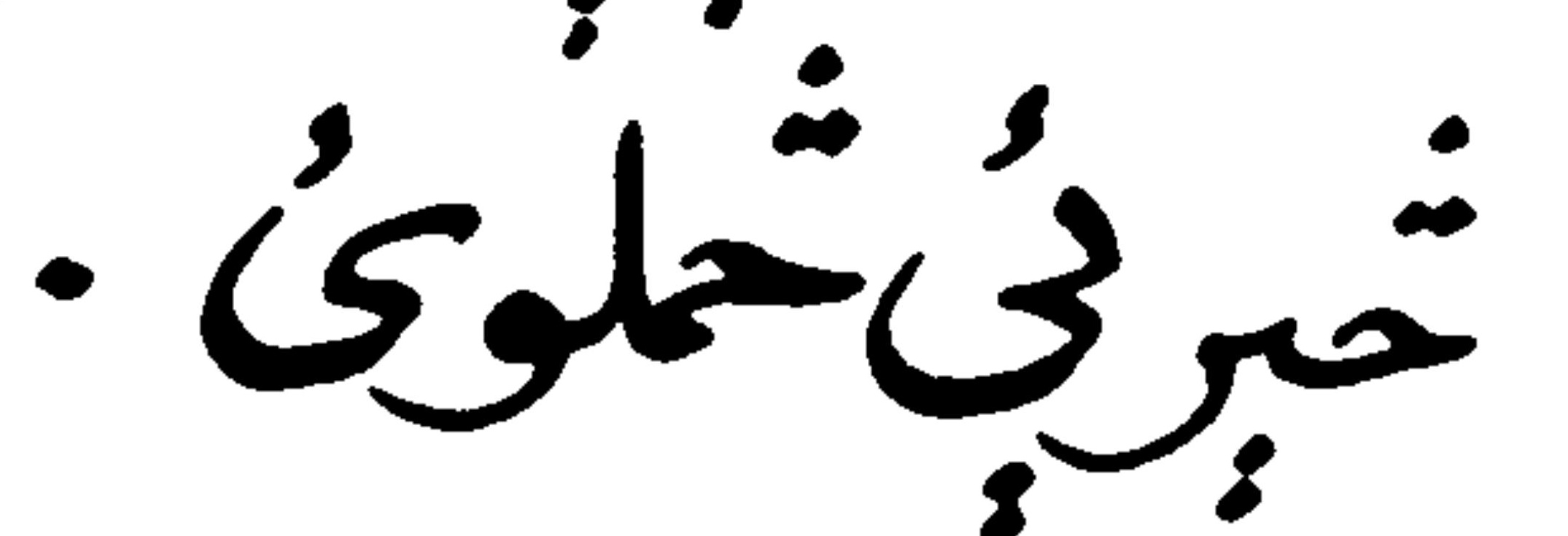




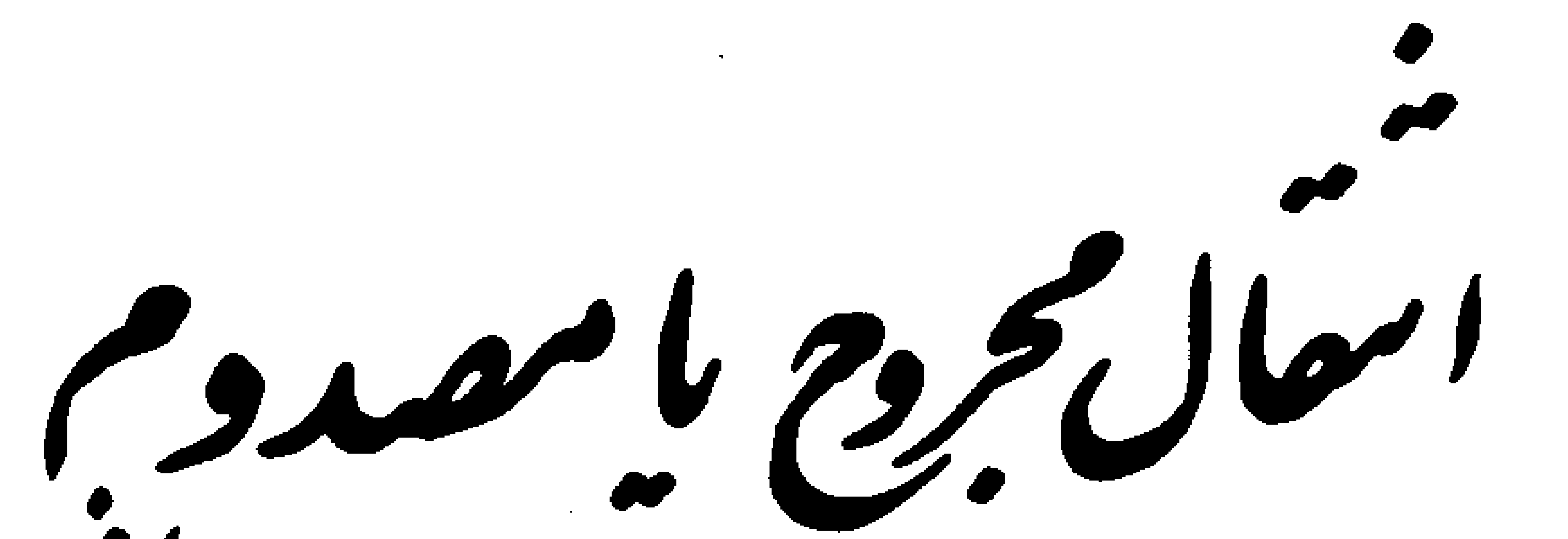

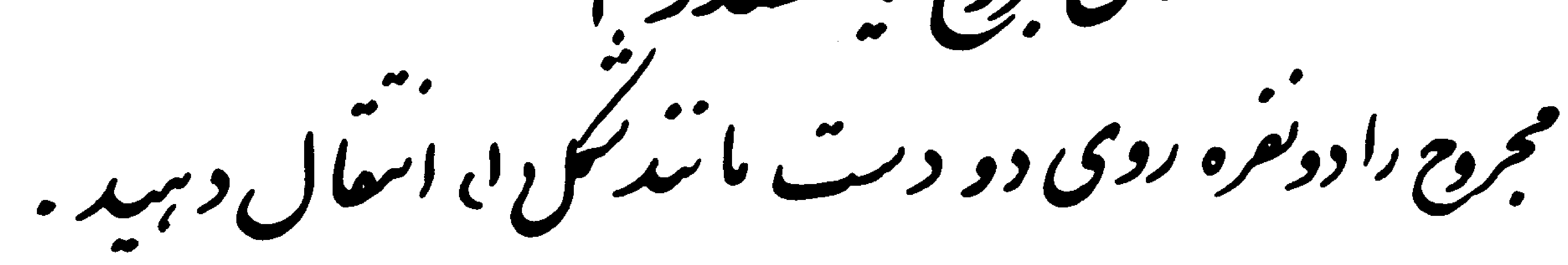

बिए के

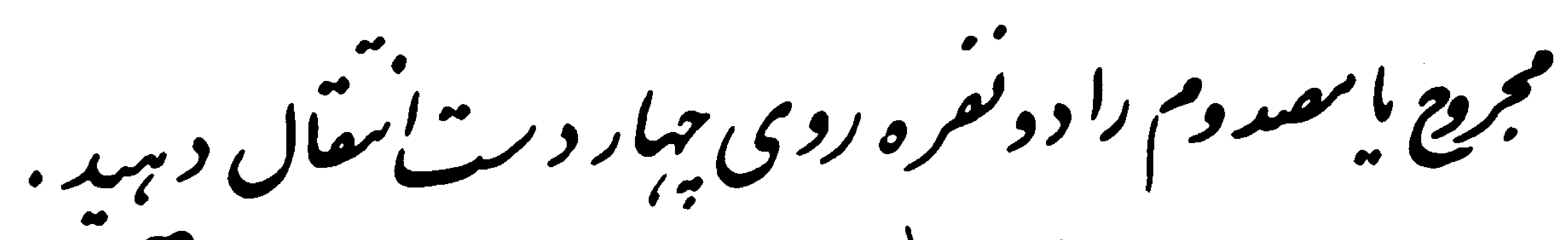

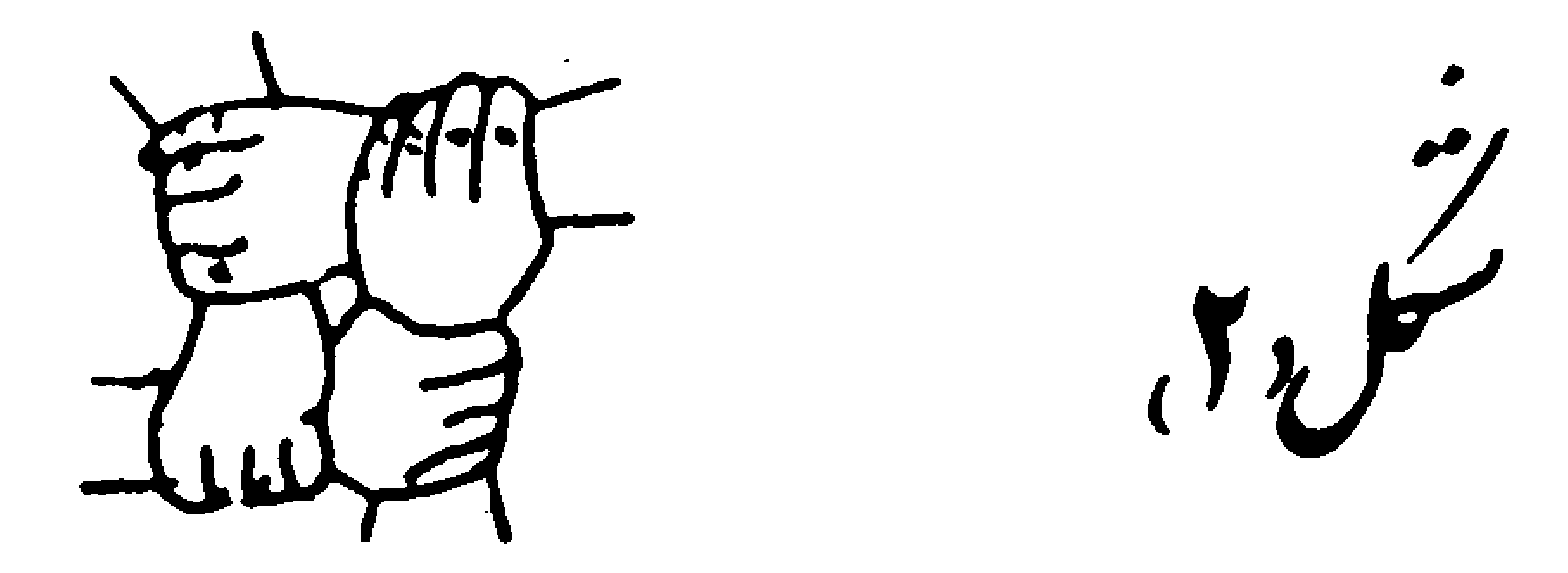

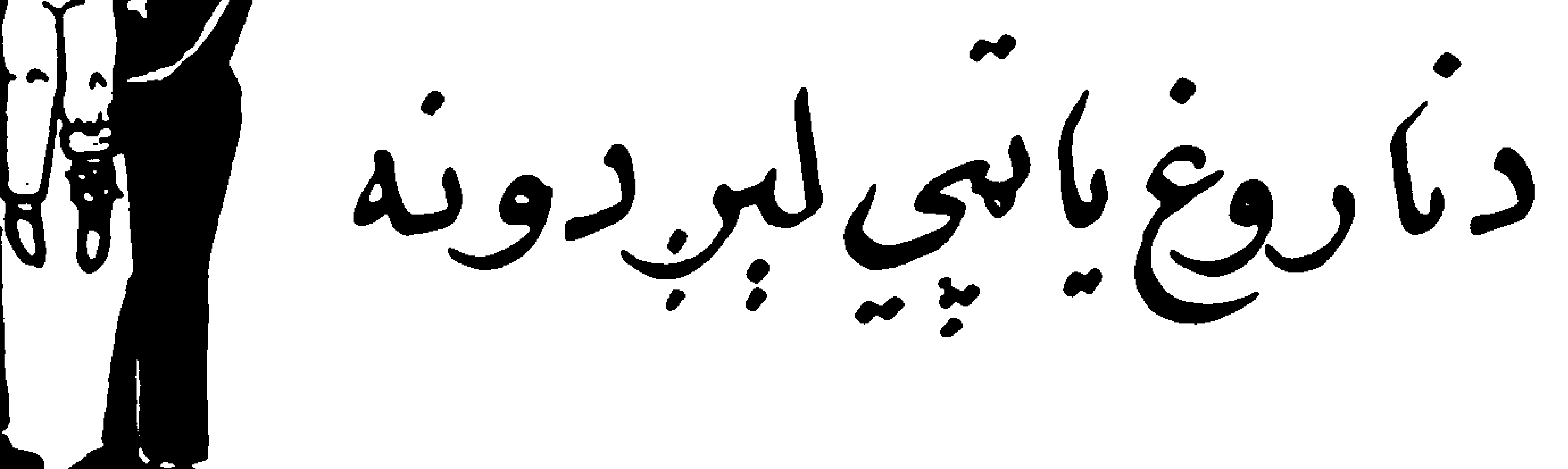

تِي د دووتولمنخايه دوولاسونودلويهيتئيل

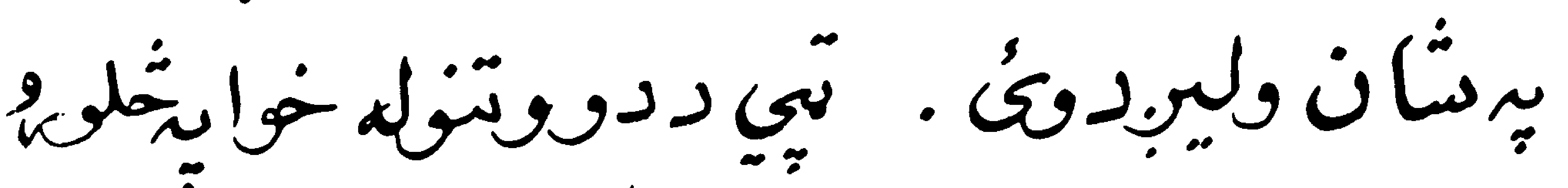

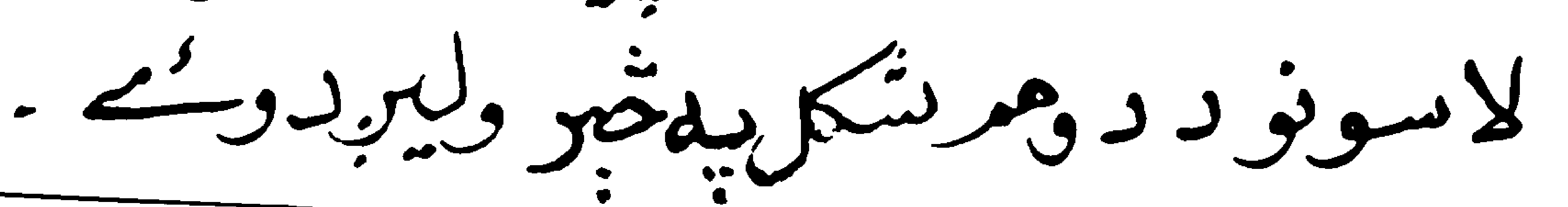




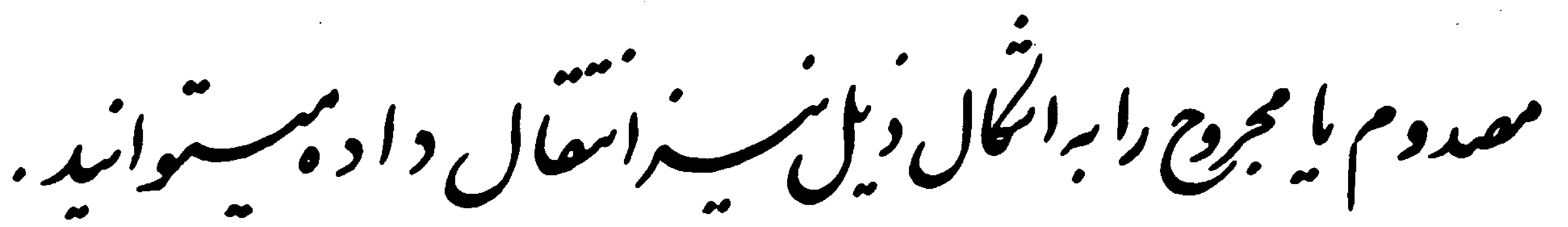

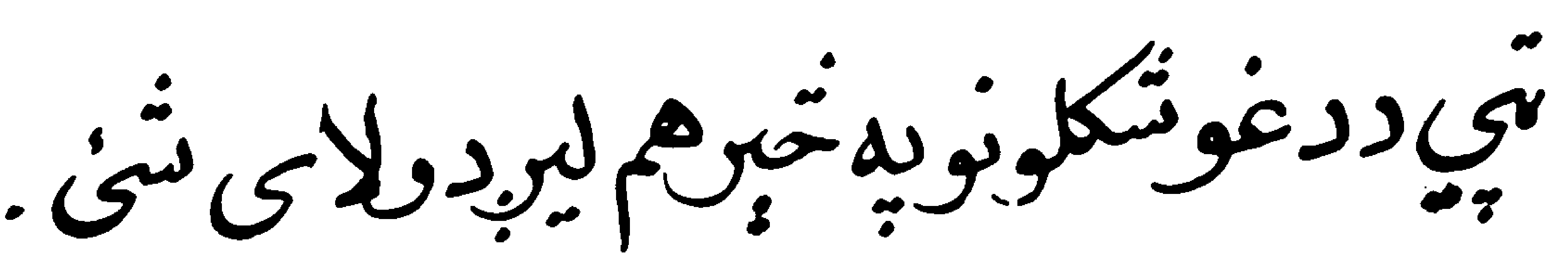

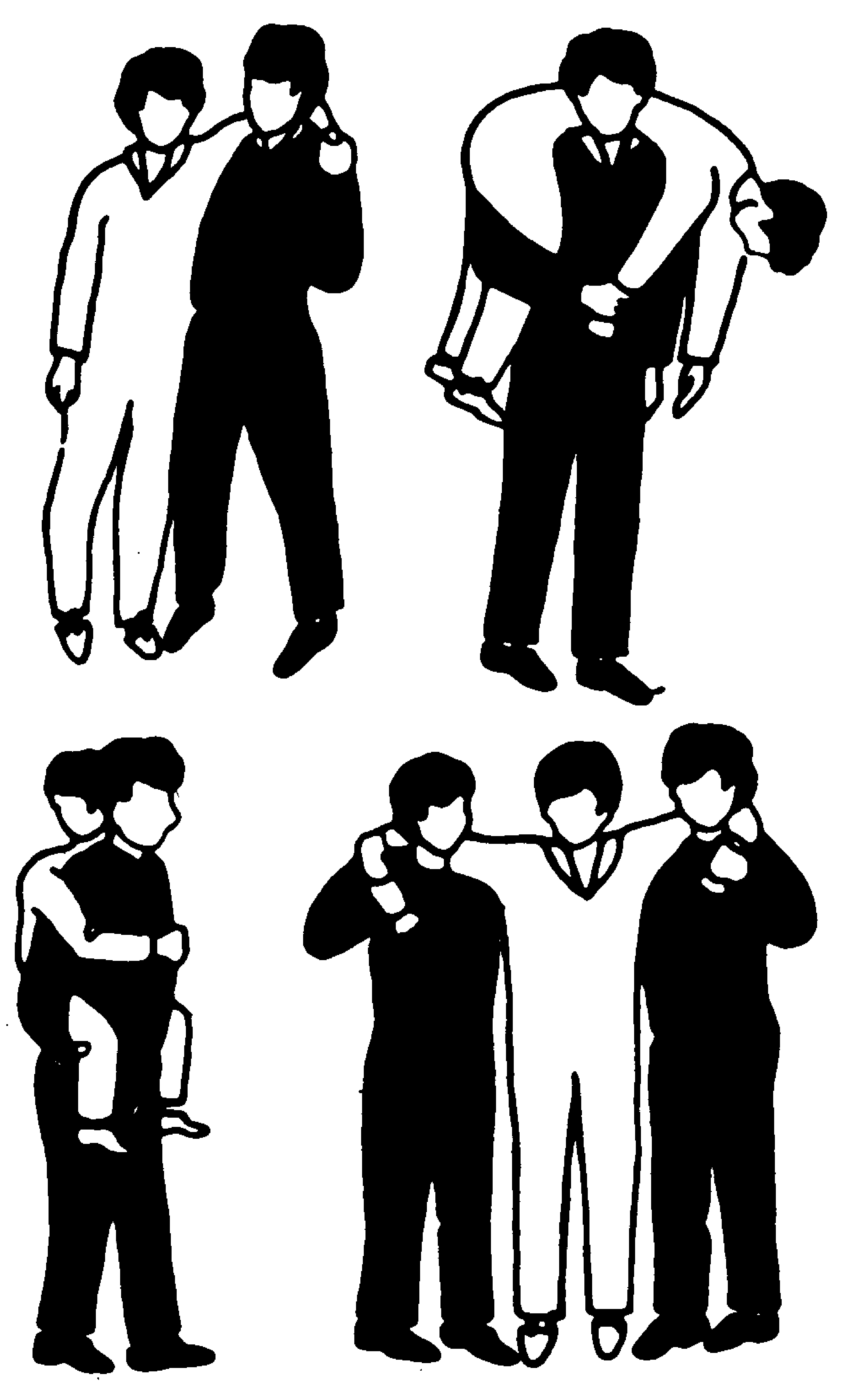




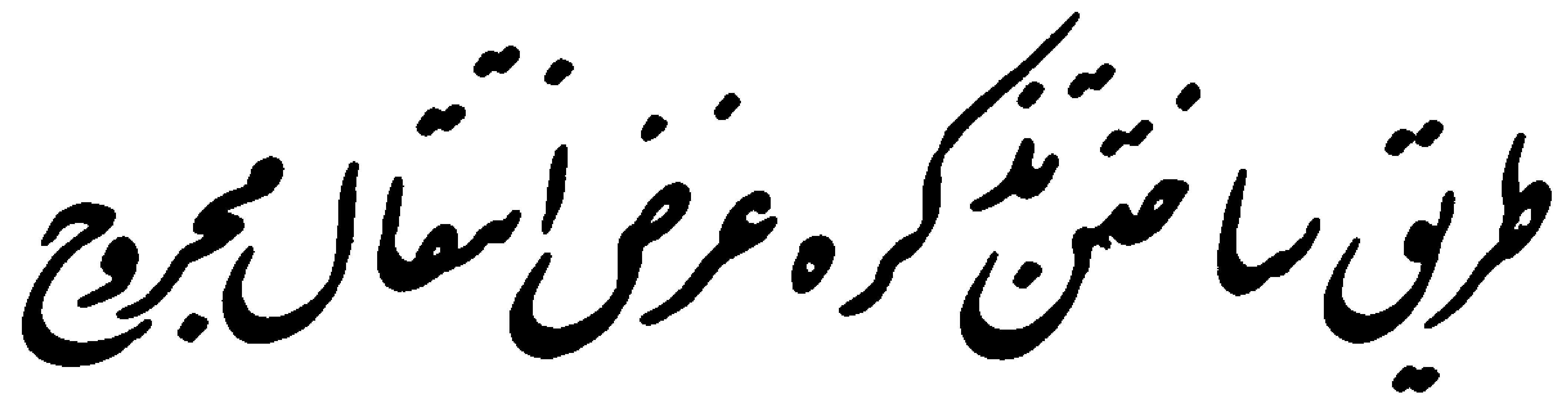

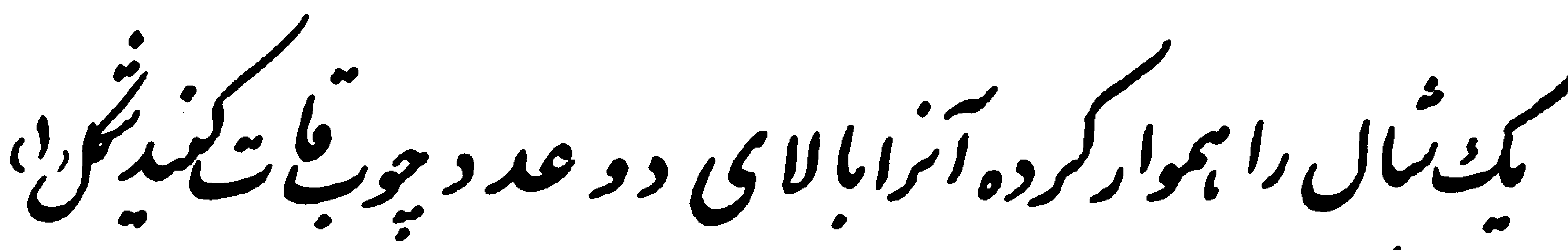

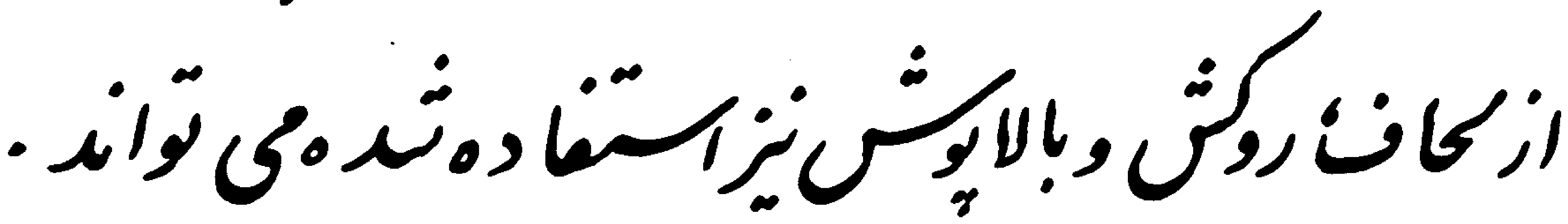
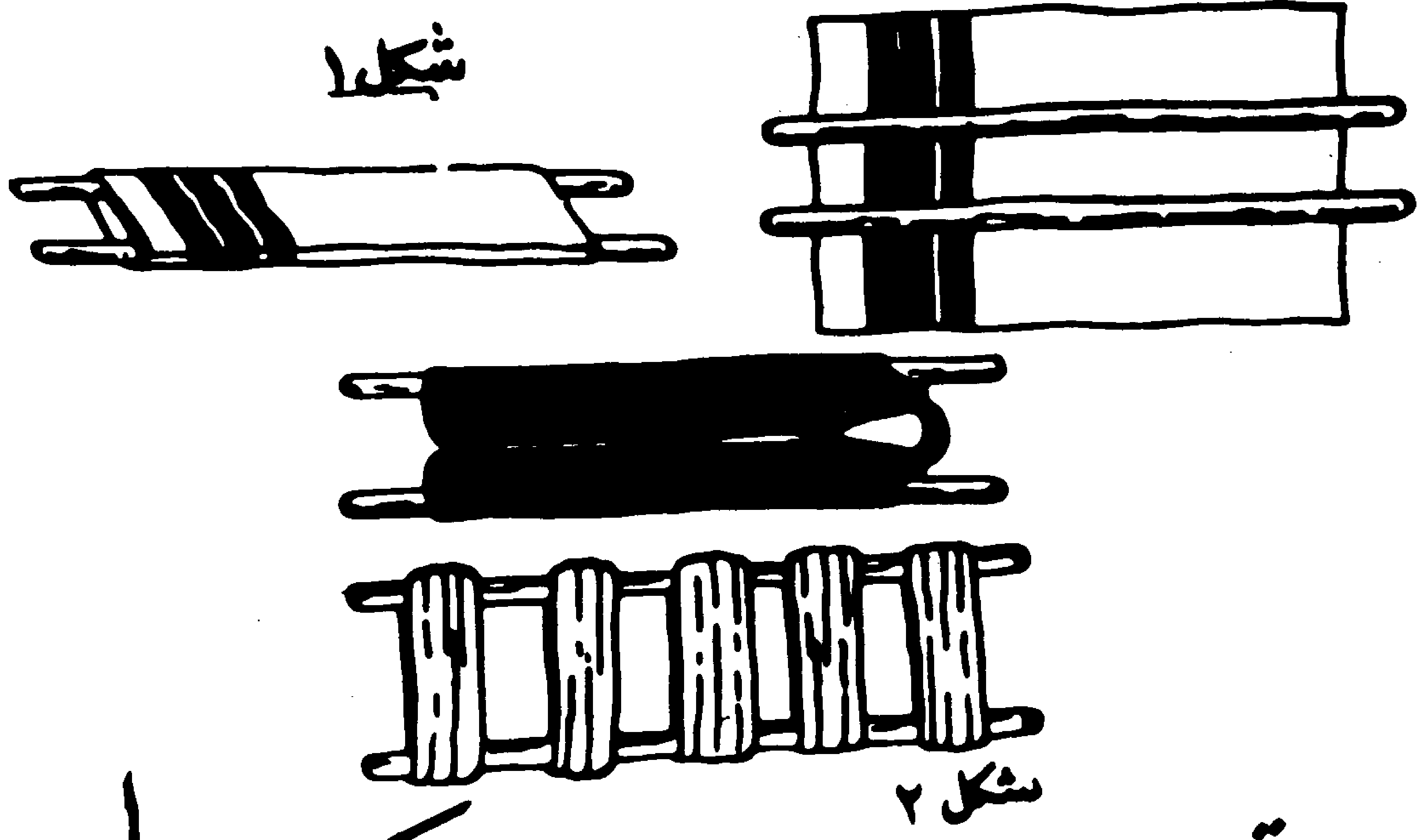

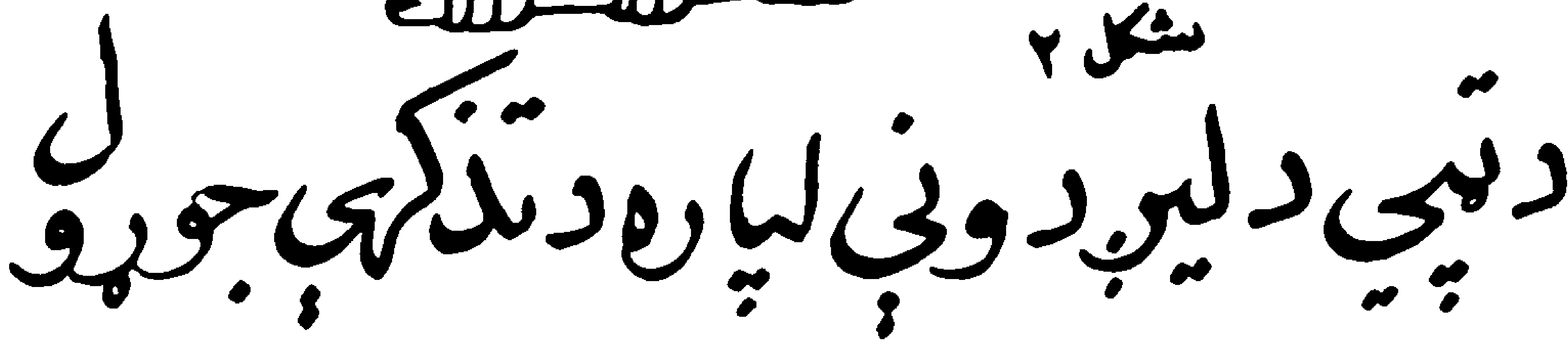

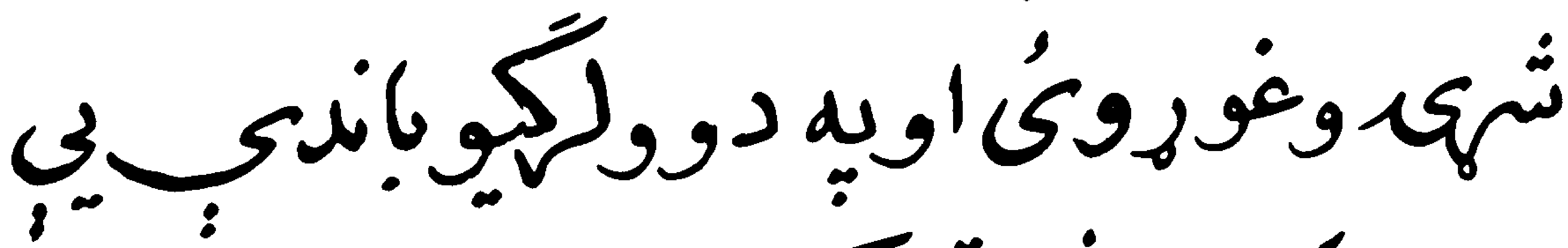

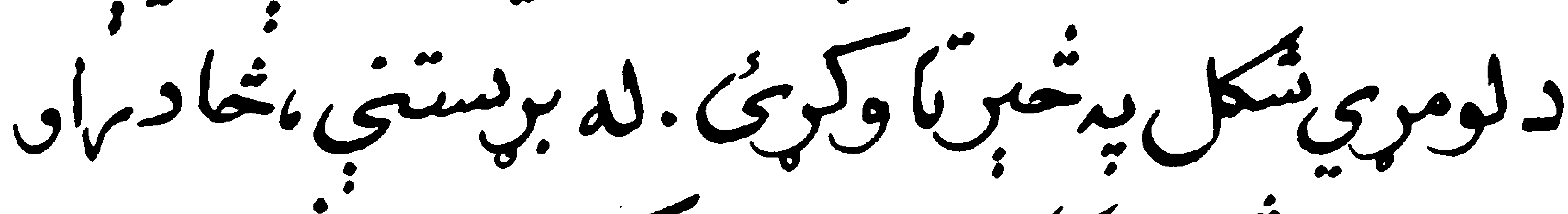

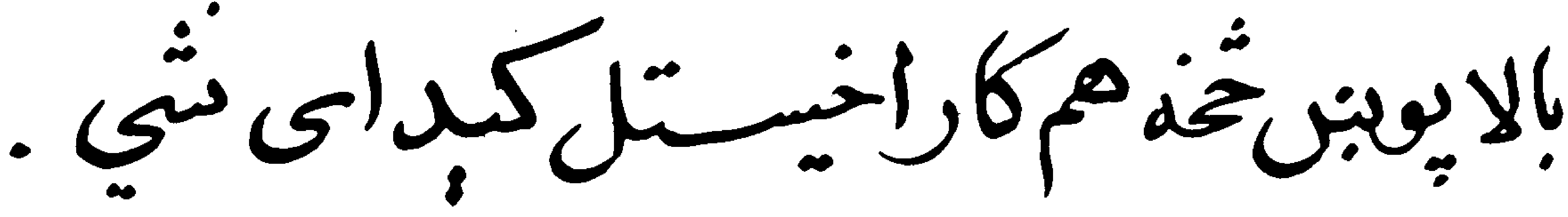




\section{$080^{\prime}+1$}

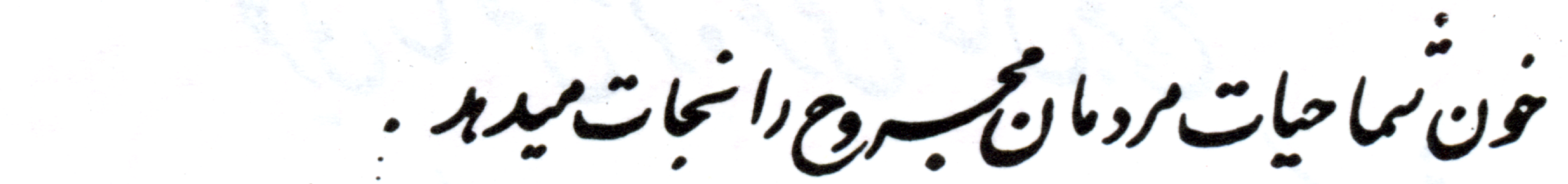

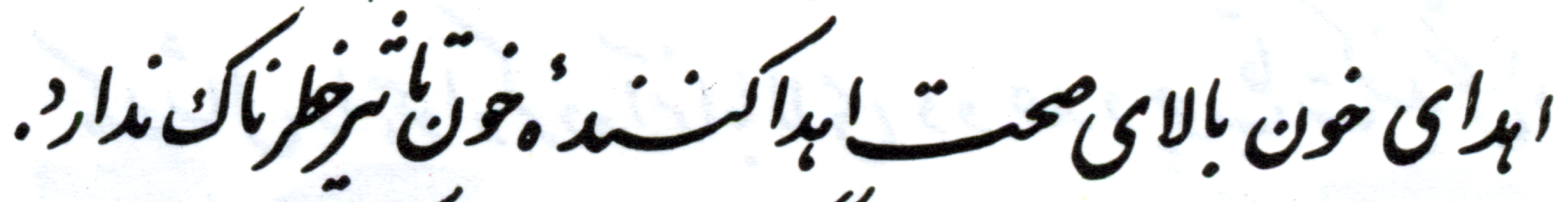

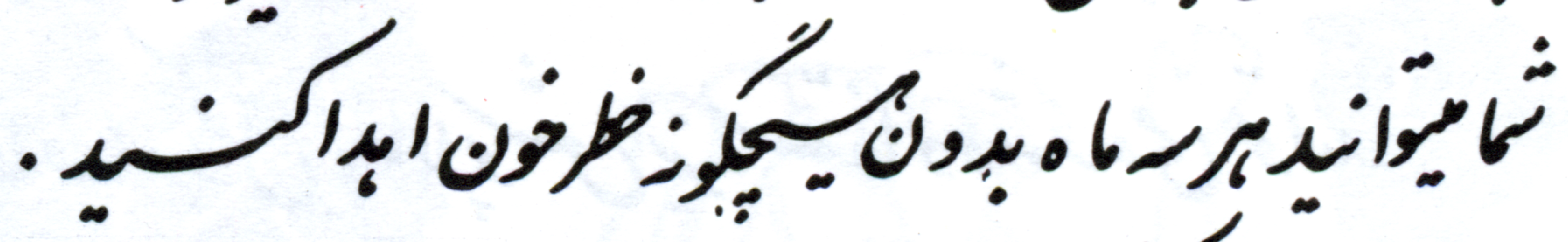
ون دونئin

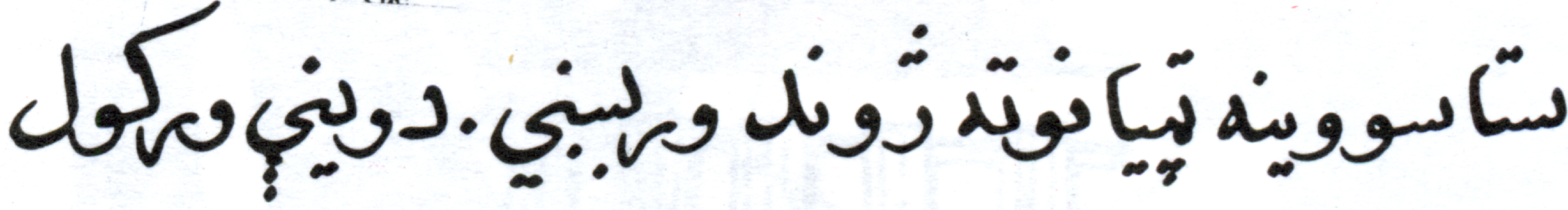

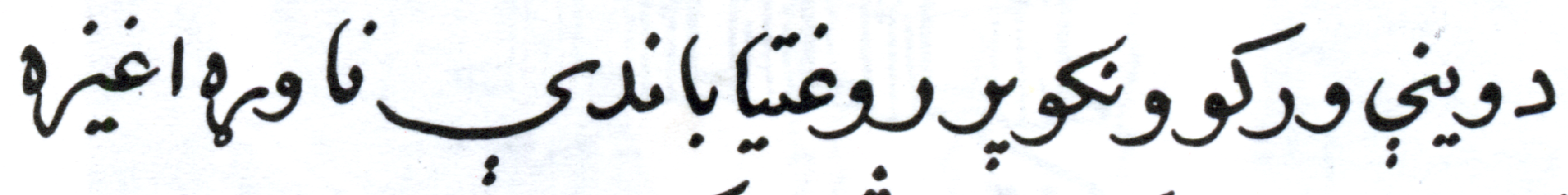

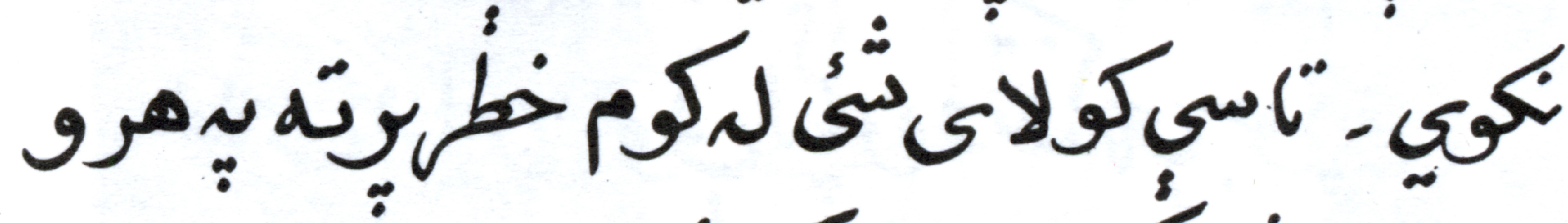

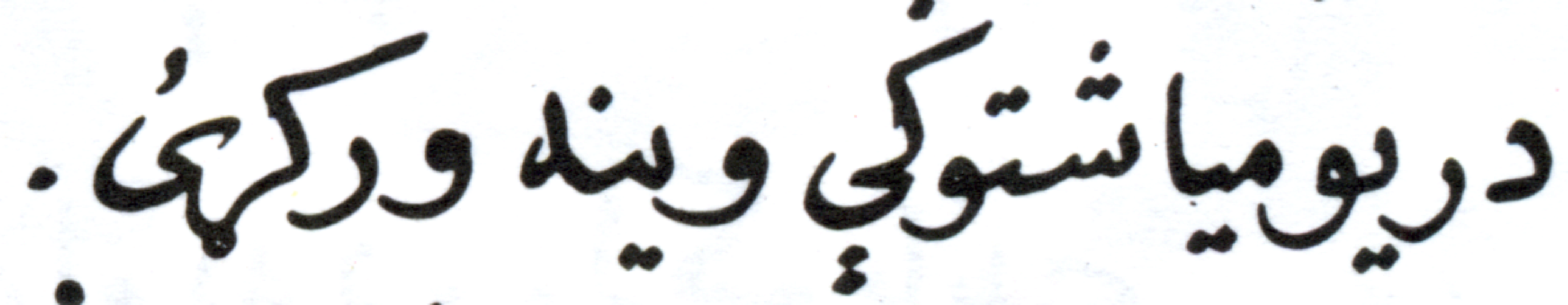

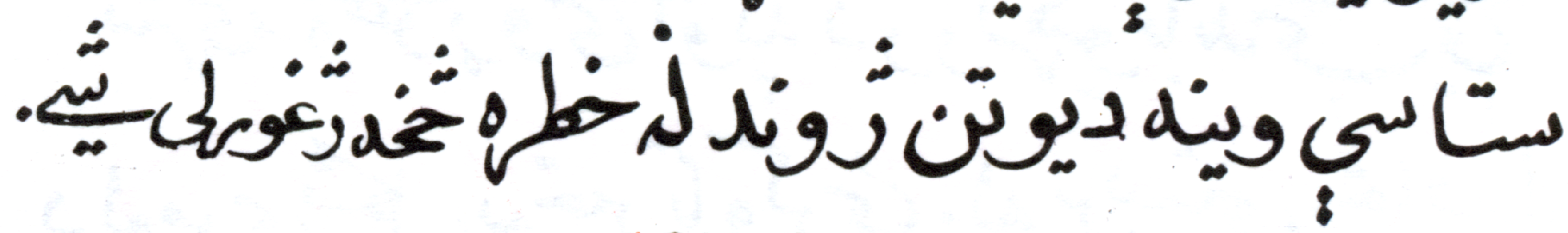

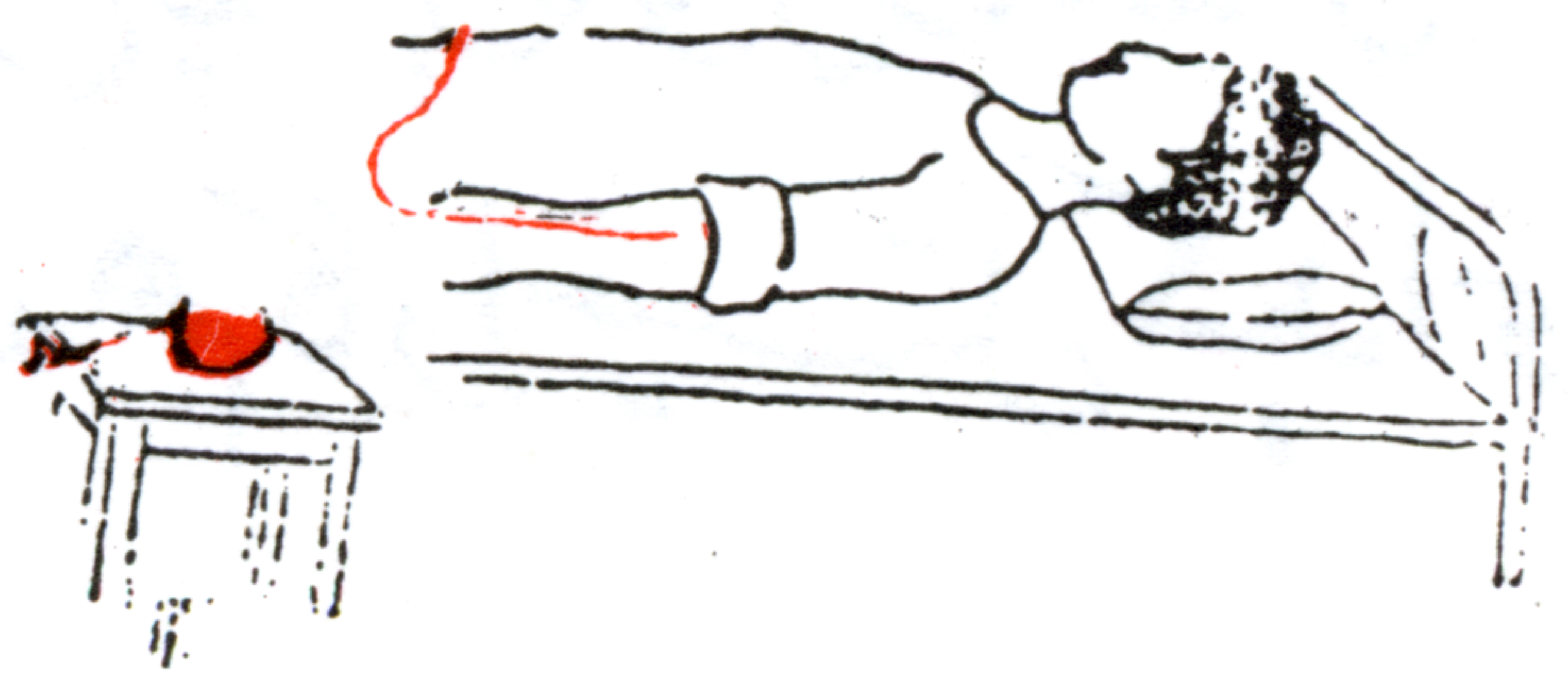




\section{ron}

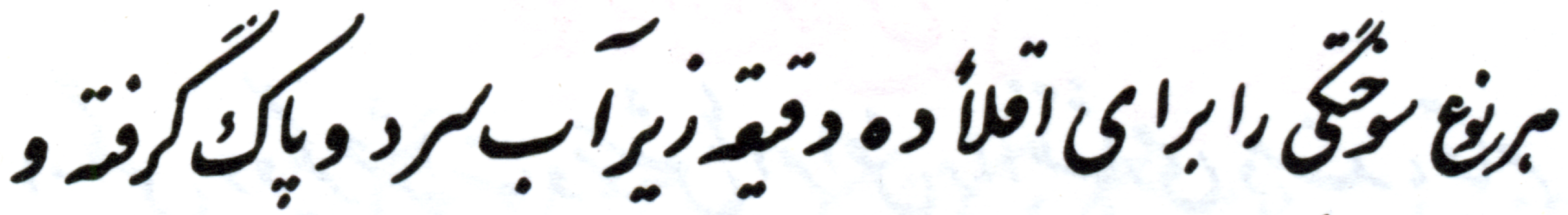

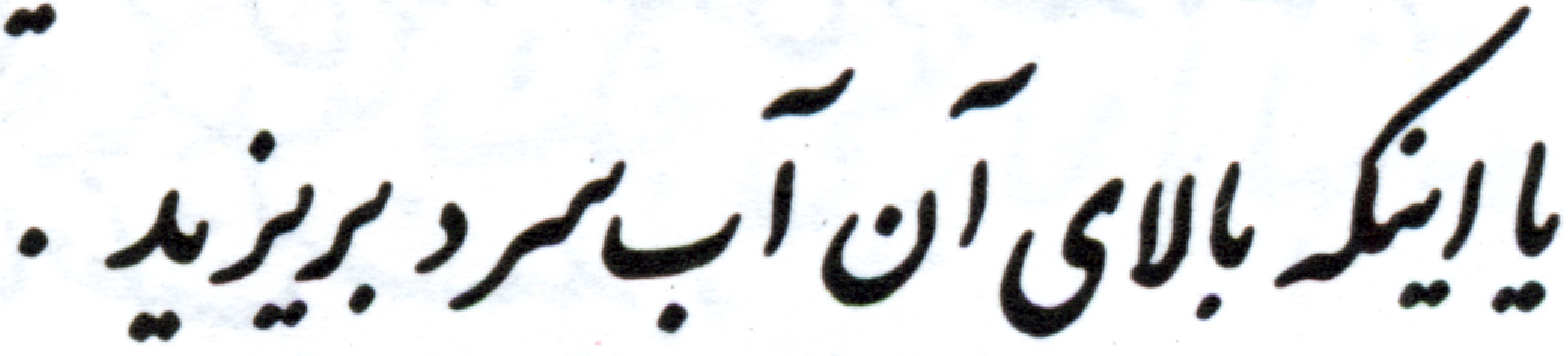

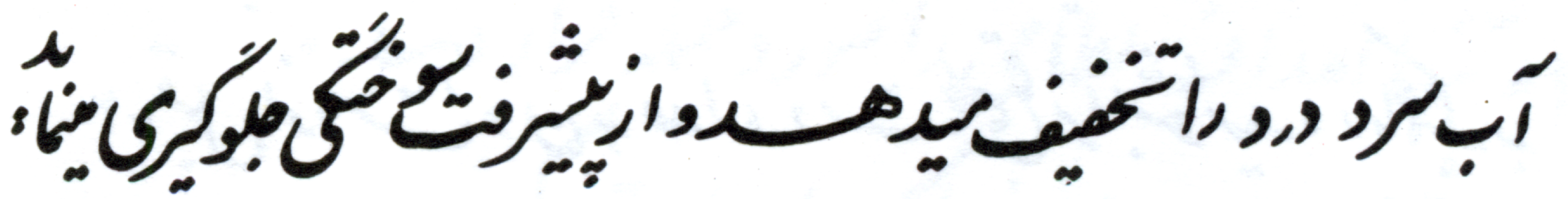

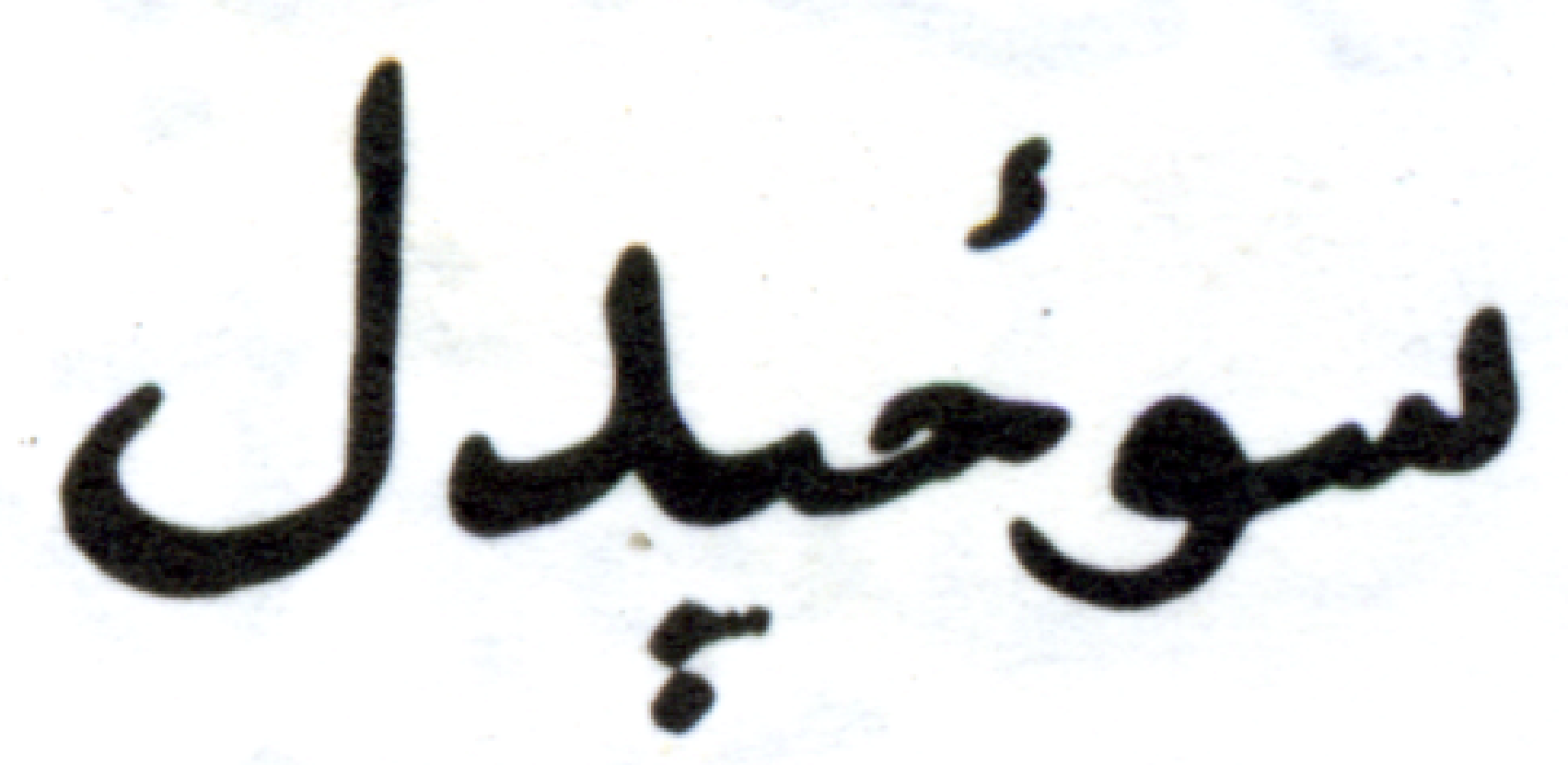

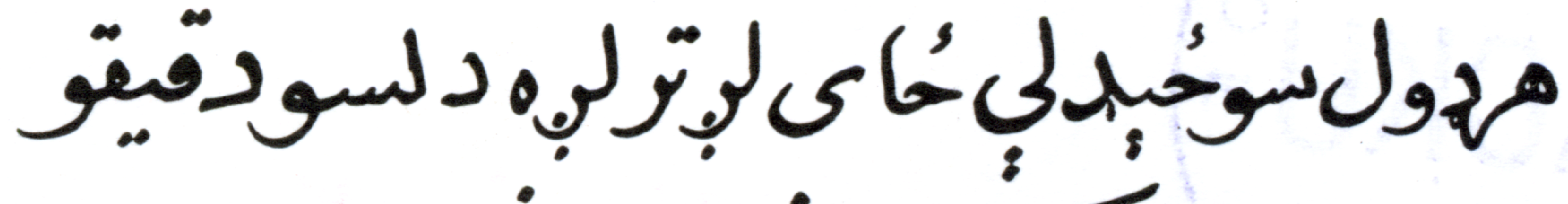

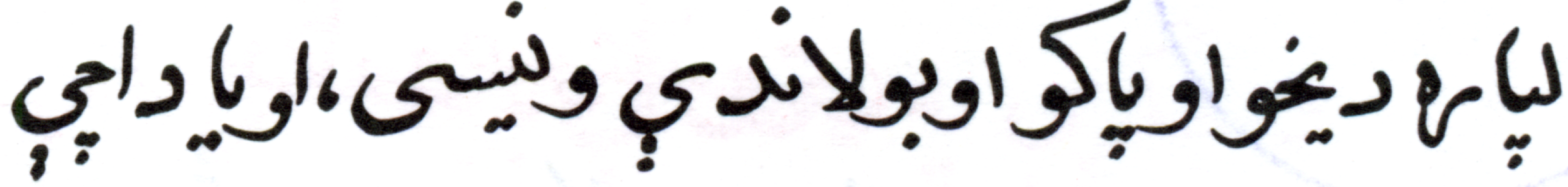

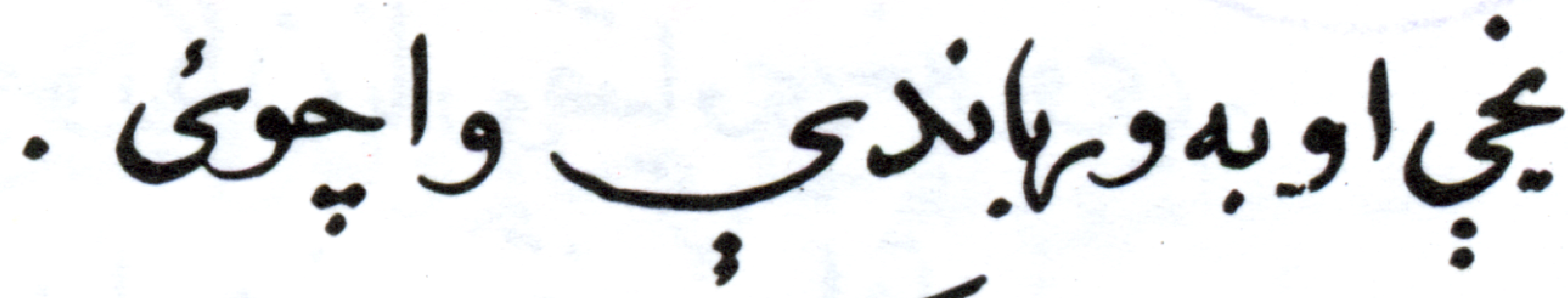

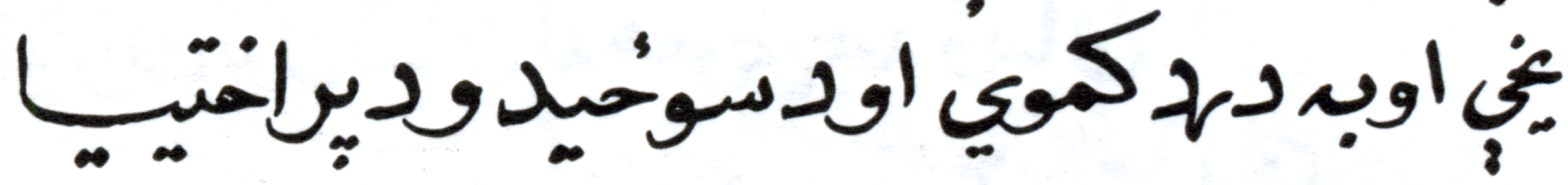

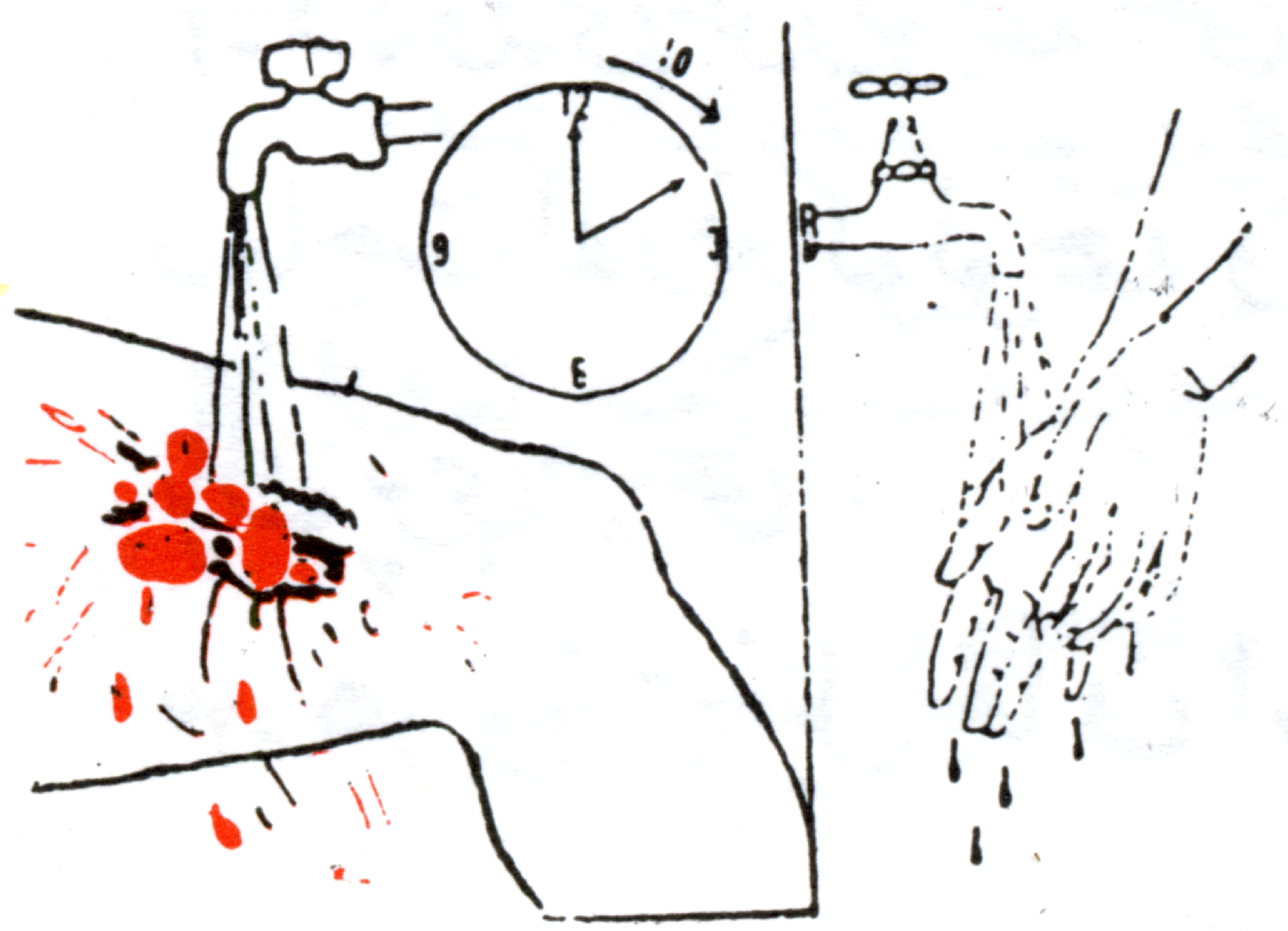

مخه يسيى . 


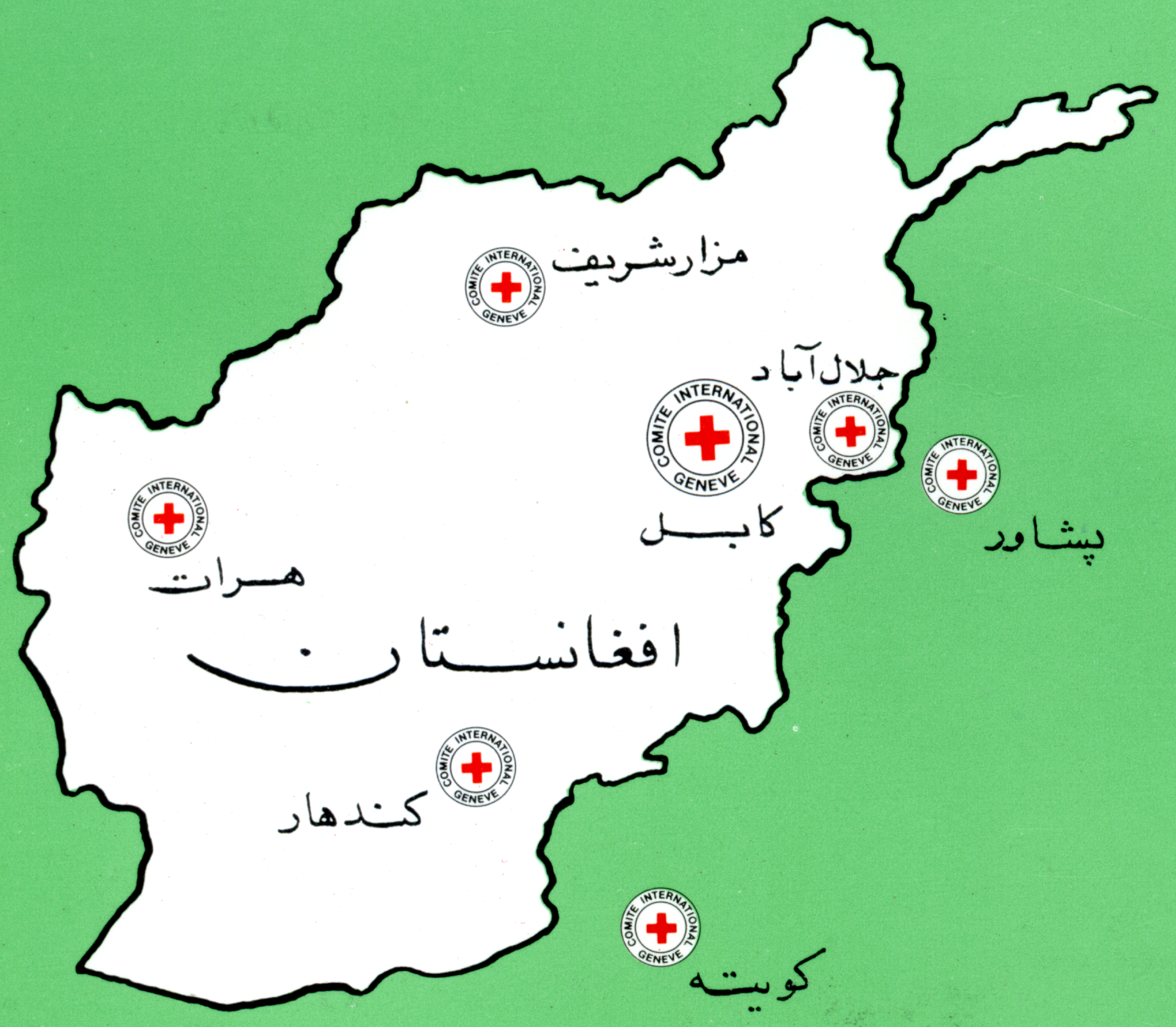

ICRC
RABLCATION
KA UL 1996 


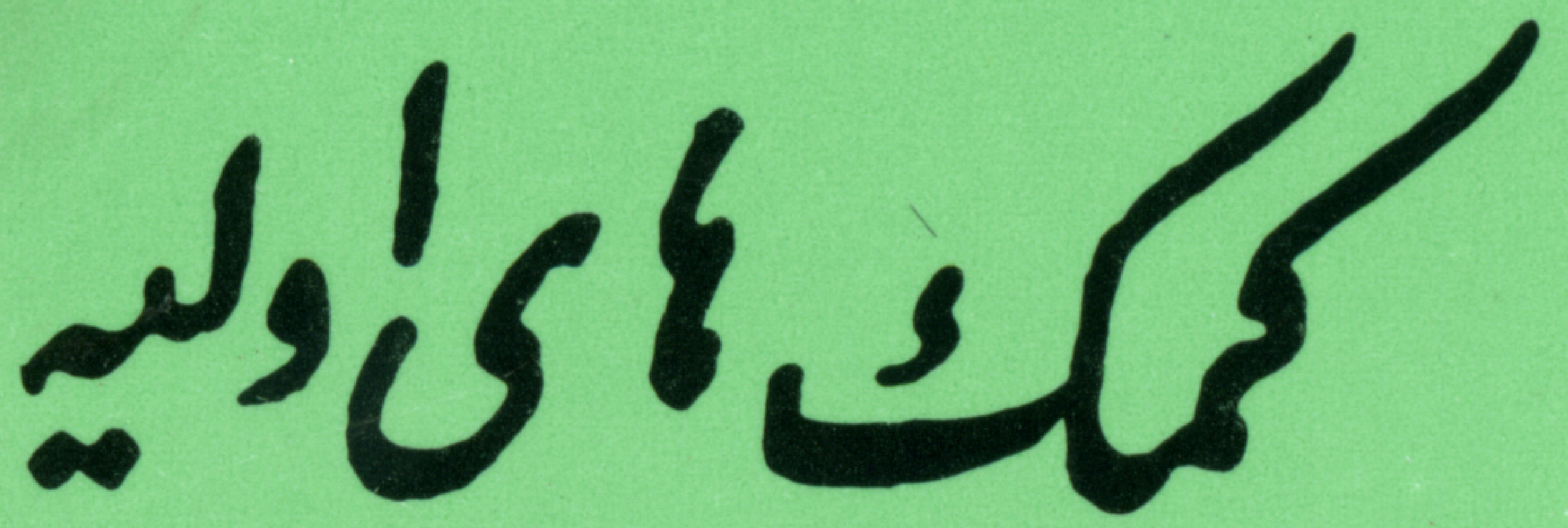
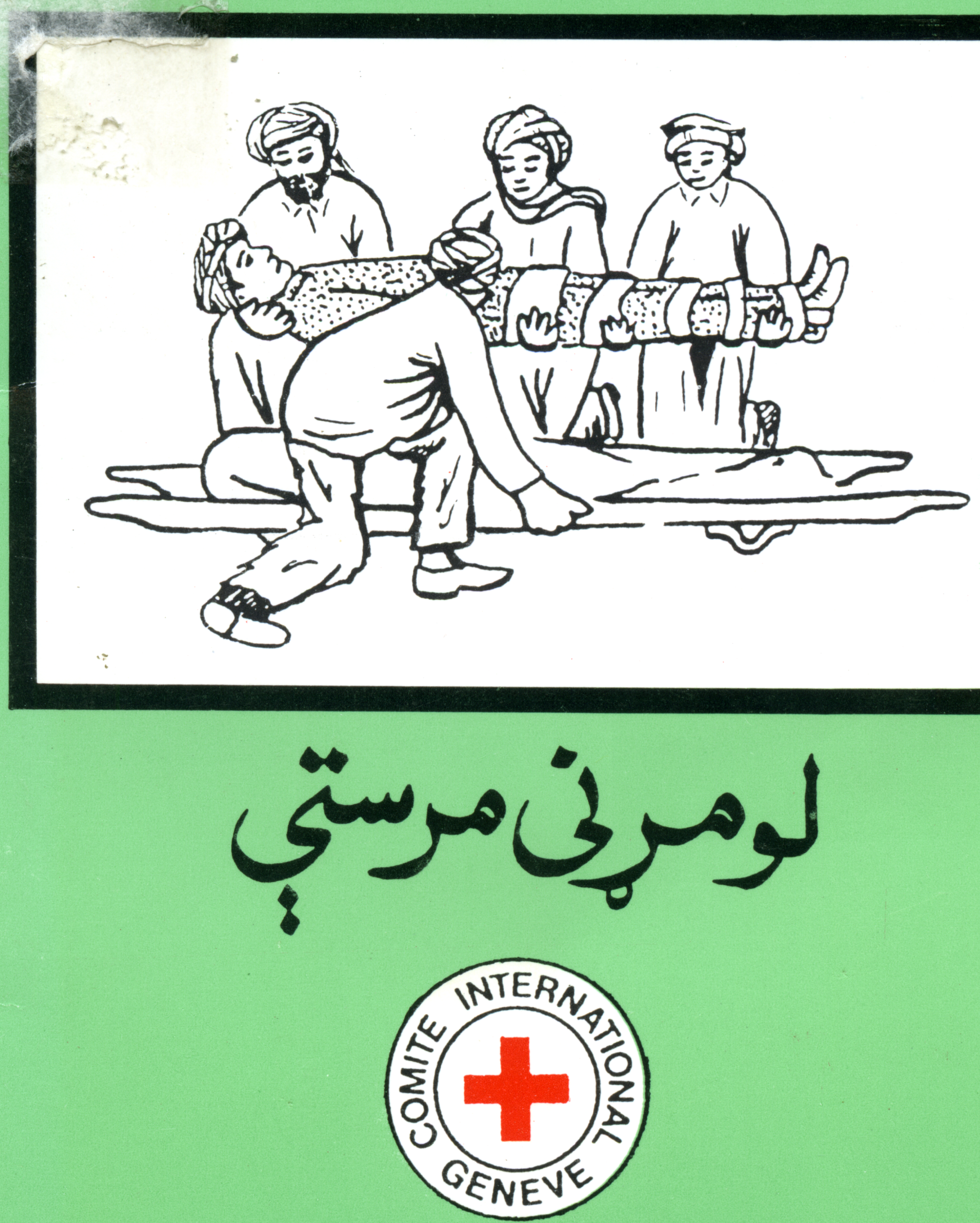